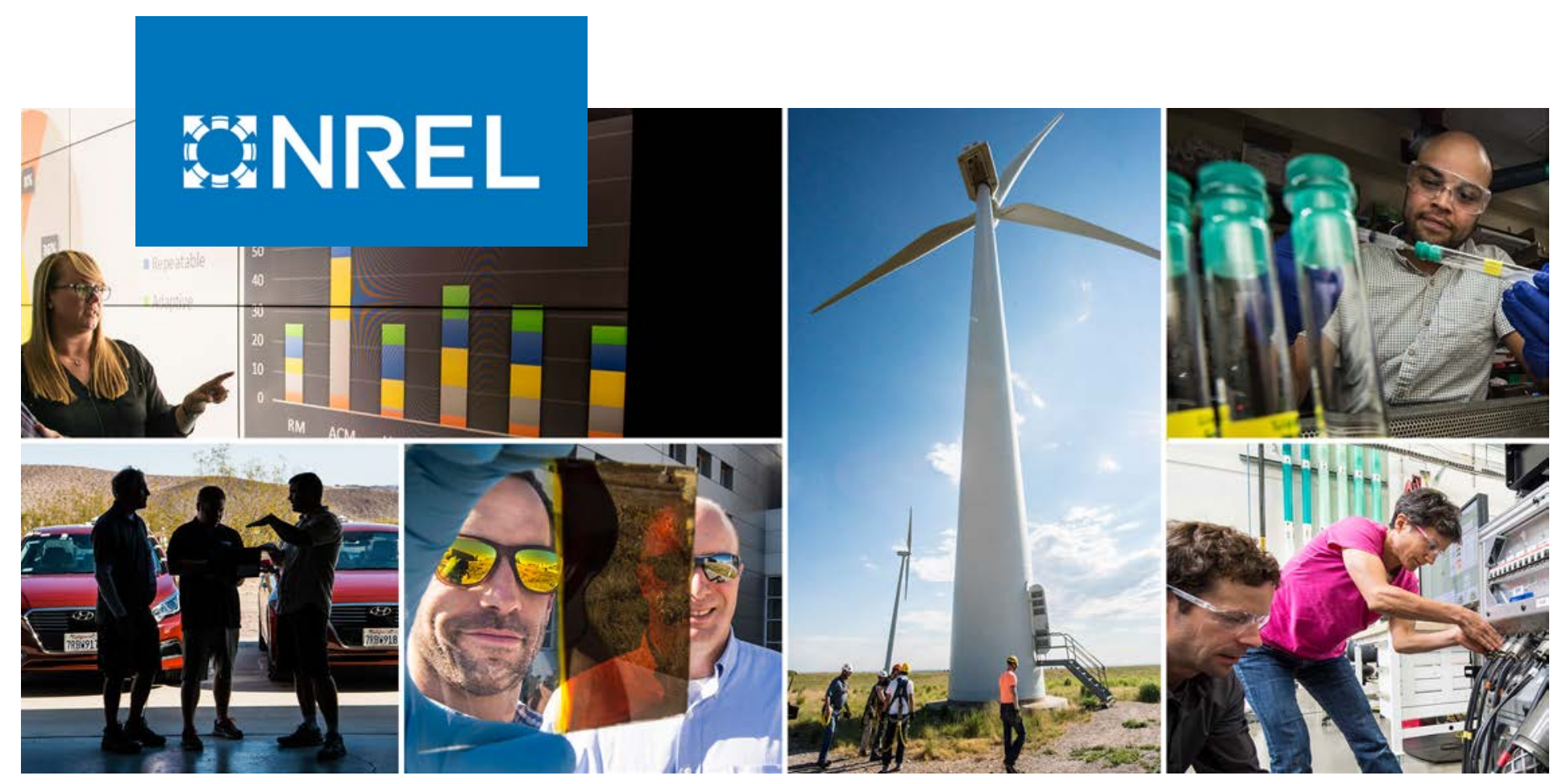

\title{
Resource Assessment for Hydrogen Production
}

Elizabeth Connelly, Michael Penev, Anelia Milbrandt, Billy Roberts, Nicholas Gilroy, and Marc Melaina

National Renewable Energy Laboratory

NREL is a national laboratory of the U.S. Department of Energy

Office of Energy Efficiency \& Renewable Energy

Operated by the Alliance for Sustainable Energy, LLC

This report is available at no cost from the National Renewable Energy Laboratory (NREL) at www.nrel.gov/publications.

\section{Technical Report}

NREL/TP-5400-77198

July 2020 


\title{
GHREL
}

\section{Resource Assessment for Hydrogen Production}

\author{
Elizabeth Connelly, Michael Penev, Anelia Milbrandt, \\ Billy Roberts, Nicholas Gilroy, and Marc Melaina
}

National Renewable Energy Laboratory

\section{Suggested Citation}

Connelly, Elizabeth, Michael Penev, Anelia Milbrandt, Billy Roberts, Nicholas Gilroy, and Marc Melaina. 2020. Resource Assessment for Hydrogen Production. Golden, CO:

National Renewable Energy Laboratory. NREL/TP-5400-77198.

https://www.nrel.gov/docs/fy20osti/77198.pdf

NREL is a national laboratory of the U.S. Department of Energy Office of Energy Efficiency \& Renewable Energy Operated by the Alliance for Sustainable Energy, LLC

This report is available at no cost from the National Renewable Energy Laboratory (NREL) at www.nrel.gov/publications.

Contract No. DE-AC36-08GO28308
Technical Report NREL/TP-5400-77198 July 2020

National Renewable Energy Laboratory 15013 Denver West Parkway Golden, CO 80401 303-275-3000 • www.nrel.gov 


\section{NOTICE}

This work was authored by the National Renewable Energy Laboratory, operated by Alliance for Sustainable Energy, LLC, for the U.S. Department of Energy (DOE) under Contract No. DE-AC36-08GO28308. Funding provided by U.S. Department of Energy Office of Energy Efficiency and Renewable Energy Hydrogen and Fuel Cell Technologies Office. The views expressed herein do not necessarily represent the views of the DOE or the U.S. Government.

This report is available at no cost from the National Renewable Energy Laboratory (NREL) at www.nrel.gov/publications.

U.S. Department of Energy (DOE) reports produced after 1991 and a growing number of pre-1991 documents are available free via www.OSTI.gov.

Cover Photos by Dennis Schroeder: (clockwise, left to right) NREL 51934, NREL 45897, NREL 42160, NREL 45891, NREL 48097, NREL 46526.

NREL prints on paper that contains recycled content. 


\section{Acknowledgments}

Funding for this work was provided by the U.S. Department of Energy (DOE) Office of Energy Efficiency and Renewable Energy Hydrogen and Fuel Cell Technologies Office. The authors particularly appreciate the support and guidance provided by DOE program manager Fred Joseck; Office Director Sunita Satyapal; and acting Deputy Assistant Secretary for Transportation Michael Berube.

The authors would also like to acknowledge and thank Chad Hunter (NREL), Mark Ruth (NREL), Tim Brown (First Element), Manussawee Sukunta (U.S. Energy Information Administration), Michael Scott (U.S. Energy Information Administration), and Susan Schoenung (Longitude $122 \mathrm{West}$ ) for their comments and suggestions in reviewing earlier versions of this report. The authors also thank Richard Boardman (Idaho National Laboratory), Jim O'Brien (Idaho National Laboratory), Tom O’Connor (DOE Office of Nuclear Energy), Becky Onuschak (DOE Office of Nuclear Energy), Tim Beville (DOE Office of Nuclear Energy), and Alison Hahn (DOE Office of Nuclear Energy) for reviewing sections of the report related to uranium resources. The authors thank Zia Haq (DOE Bioenergy Technologies Office) for reviewing the biomass section and assumptions. The authors also thank John Litynski (DOE Office of Fossil Energy), Patrick Gilman (DOE Wind Energy Technologies Office), Avi Shultz (DOE Solar Energy Technologies Office), Tim Ramsey (DOE Water Power Technologies Office), and Jeff Winick (DOE Geothermal Technologies Office) for their helpful comments and suggestions. Thanks also go to Galen Maclaurin (NREL), Paul Denholm (NREL), and Shih-chieh Kao for providing data on technical resources. The authors also appreciate the review and guidance provided by Christopher Munson (DOE) related to the fossil fuel resources. In addition, the authors thank the H2@Scale project team, including Fred Joseck (DOE) and Neha Rustagi (DOE), for advice especially regarding visualizations presented in this report. Many improvements were made to the analysis and substance of the report in response to reviewer feedback.

The analysis results presented here build upon analysis work and data preparation completed for earlier reports by Anelia Milbrandt and Margaret Mann (2007; 2009); Marc Melaina, Michael Penev, and Donna Heimiller (2013); and Anthony Lopez, Donna Heimiller, and other NREL staff (Lopez et al. 2012). These earlier reports are cited when directly referenced. This analysis also builds upon previous comparisons of future hydrogen demands to projected energy supply trends in the 2011 Program Plan for the U.S. Department of Energy's Fuel Cell Technologies Office (DOE 2011). These existing studies facilitated the process of updating data and resource analyses and establishing general framework for discussing energy resources and hydrogen production potentials. 


\section{Acronyms}

\begin{tabular}{|c|c|}
\hline AEO & Annual Energy Outlook \\
\hline AWARE & available water remaining \\
\hline BAU & business as usual \\
\hline Btu & British thermal units \\
\hline CSP & concentrating solar power \\
\hline DOE & U.S. Department of Energy \\
\hline DRB & Demonstrated Reserve Base \\
\hline EERE & Energy Efficiency and Renewable Energy \\
\hline EGS & enhanced geothermal systems \\
\hline EHA & existing hydropower assets \\
\hline EIA & U.S. Energy Information Administration \\
\hline FCEV & fuel cell electric vehicle \\
\hline GHG & greenhouse gas \\
\hline GREET & $\begin{array}{l}\text { Greenhouse gases, Regulated Emissions, and Energy use in } \\
\text { Transportation }\end{array}$ \\
\hline GW & gigawatt \\
\hline GWh & gigawatt-hour \\
\hline GWdt & gigawatt-days thermal \\
\hline $\mathrm{H} 2 \mathrm{~A}$ & Hydrogen Analysis \\
\hline $\mathrm{HHV}$ & higher heating value \\
\hline HTE & high-temperature electrolysis \\
\hline HTGR & high-temperature gas-cooled reactor \\
\hline IAEA & International Atomic Energy Agency \\
\hline $\mathrm{kg}$ & kilogram \\
\hline $\mathrm{kWh}$ & kilowatt-hour \\
\hline LDV & light-duty vehicle \\
\hline LHV & lower heating value \\
\hline LTE & low-temperature electrolysis \\
\hline LWR & light-water reactor \\
\hline MHK & marine and hydrokinetics \\
\hline $\mathrm{MJ}$ & megajoule \\
\hline
\end{tabular}




$\begin{array}{ll}\text { MMT } & \text { million metric tonnes } \\ \text { MW } & \text { megawatt } \\ \text { MWt } & \text { megawatt-thermal } \\ \text { NEA } & \text { Nuclear Energy Agency } \\ \text { NETL } & \text { National Energy Technology Laboratory } \\ \text { NREL } & \text { National Renewable Energy Laboratory } \\ \text { ORNL } & \text { Oak Ridge National Laboratory } \\ \text { PV } & \text { photovoltaic } \\ \text { quad } & \text { quadrillion Btu } \\ \text { RAR } & \text { reasonably assured resources } \\ \text { REF } & \text { Renewable Electricity Futures } \\ \text { scf } & \text { standard cubic feet } \\ \text { Tcf } & \text { trillion cubic feet } \\ \text { ton } & \text { short ton }(2,000 \mathrm{lb}) \\ \text { tonne } & \text { metric tonne }(1,000 \text { kg) } \\ \text { TWh } & \text { terawatt-hour } \\ \text { U } & \text { uranium } \\ \mathrm{U}_{3} \mathrm{O}_{8} & \text { uranium oxide } \\ \text { USGS } & \text { United States Geological Survey }\end{array}$




\section{Executive Summary}

In support of the Spark M. Matsunaga Hydrogen Act of 2005 (Title VIII of the Energy Policy Act) and in response to recommendations from the U.S. Department of Energy's (DOE's) Hydrogen and Fuel Cell Technical Advisory Committee, the Hydrogen and Fuel Cell Technologies Office has been carrying out analyses to determine the availability of resources within the United States to provide hydrogen under different demand scenarios. ${ }^{1}$ This analysis was conducted in support of DOE's H2@Scale initiative, ${ }^{2}$ and this report examines the resources required to meet demand for an additional 10 million metric tonnes (MMT) of hydrogen in $2040 .^{3}$

The technical potential of hydrogen production from fossil, nuclear, and renewable energy resources is presented. Updated maps describe the geographical distribution of hydrogen production potential from renewable energy resources. The results conclude that the technical resource availability of domestic energy resources is sufficient to meet an additional 10 MMT of hydrogen demand in 2040, without placing significant pressure on existing resources. ${ }^{4}$ Figure ES-1 shows the current (2017) and projected (2040) consumption of each energy resource, as well as the additional (individual) resource required to produce $10 \mathrm{MMT}$ of hydrogen in 2040. While this level of hydrogen demand could result in a significant increase in renewable energy consumption in particular, the technical potential of each resource is estimated to be sufficient to meet the demand.

Future research, to enable the large-scale integration of hydrogen in the U.S. energy and other sectors, will include analyzing the geographic distribution of resources in relation to hydrogen demand for a variety of applications. Additional techno-economic analysis is needed to understand the economic potential of hydrogen in other industries, beyond transportation; such analysis is currently being undertaken by a multi-lab project initiated by DOE in 2016. Finally, information from techno-economic analyses should be used to continually update and inform R\&D targets for energy production, hydrogen production, and hydrogen utilization technologies.

\footnotetext{
${ }^{1}$ The Spark M. Matsunaga Hydrogen Act of 2005 (Title VIII of the Energy Policy Act; https://www.gpo.gov/fdsys/pkg/PLAW-109pub158/pdf/PLAW-109pub158.pdf) directed the Secretary of Energy to conduct research activities "to address production of hydrogen from diverse energy resources including - fossil fuels, which may include carbon capture and sequestration; hydrogen-carrier fuels (including ethanol and methanol); renewable energy resources, including biomass; and nuclear energy." This report addresses the technical potential of hydrogen production from fossil fuels, renewable resources, and nuclear energy. Additionally, the Hydrogen Technical Advisory Committee recommended in 2017 that DOE take action to support "the potential for fuel shortages. For example, in Southern California where FCEV purchases have been strong, hydrogen fuel capacity is being outpaced by demand. Sustained investments in additional production capacity buildout is needed." This report identifies the potential for diverse methods of hydrogen production to address two future scenarios of fuel demand from fuel cell electric vehicles (FCEVs).

${ }^{2}$ https://www.energy.gov/eere/fuelcells/h2-scale

3 This future demand would be in addition to the current market demand of 10 MMT of hydrogen per year (Connelly et al. 2019). Currently, nearly all of the $10 \mathrm{MMT}$ of commercially produced hydrogen is from natural gas steam methane reforming (EIA 2020).

${ }^{4}$ While the combined technical potential of domestic resources is more than sufficient to produce an additional 10 MMT of hydrogen, this level of hydrogen production would require a significant portion of the technical potential of certain individual resources (e.g., $>20 \%$ of water power potential). In general, this analysis assesses the ability of individual resources to meet future hydrogen demand.
} 


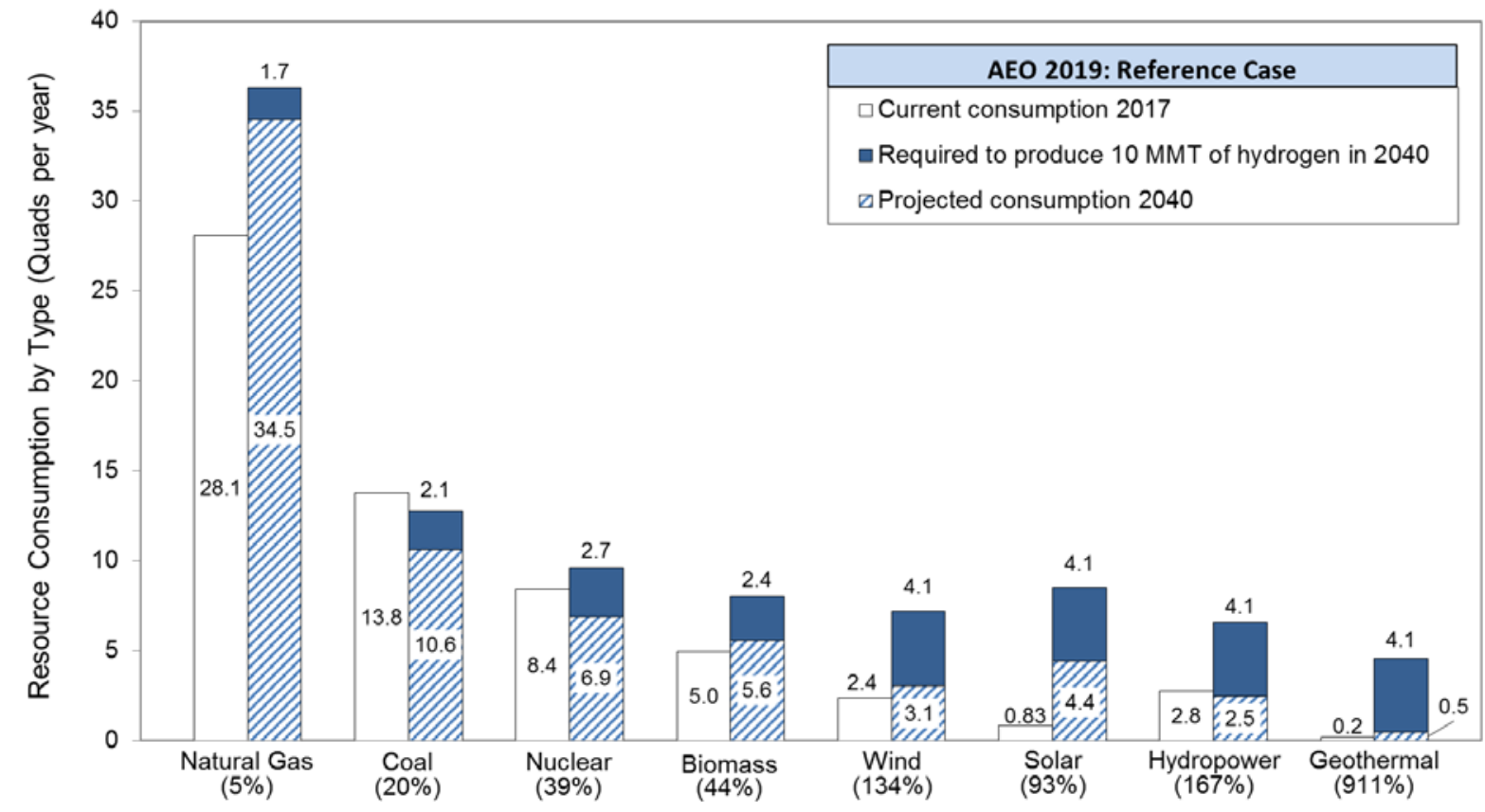

Figure ES-1. Comparison of energy resource required to produce $10 \mathrm{MMT}$ of hydrogen to current and projected energy consumption from the 2019 Annual Energy Outlook (AEO) Reference Case. ${ }^{5}$

Note: The percentages listed in parentheses represent the percent increase in 2040 projected energy consumption, by resource, that would be required to produce $10 \mathrm{MMT}$ of hydrogen.

${ }^{5}$ The demand for wind, solar, hydropower, and geothermal resources to produce 10 MMT of hydrogen is 513 terawatt-hours, which is converted to quads using the U.S. Energy Information Administration (EIA) fossil fuel heat rate of 8,017 British thermal units per kilowatt-hour in 2040, to enable comparison with the EIA projected resource consumption estimates. As a result, the energy requirements for the low-temperature electrolysis pathways appear higher than coal and biomass gasification, despite having a higher conversion efficiency. 


\section{Table of Contents}

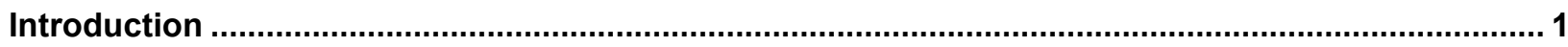

Estimates for Fossil Fuel and Nuclear Resources .................................................................. 4

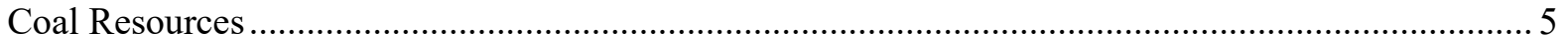

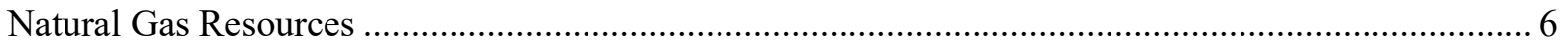

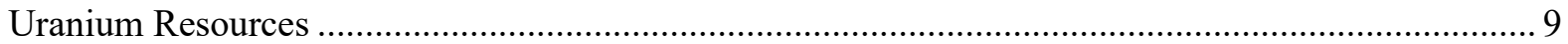

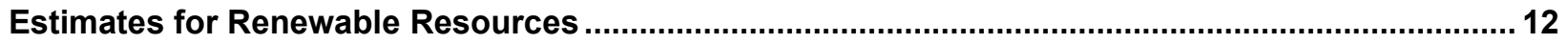

Biomass Resources ........................................................................................ 14

Wind Resources............................................................................................... 15

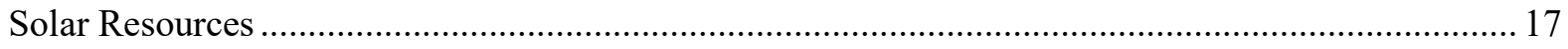

Water Power Resources............................................................................................... 21

Geothermal Resources......................................................................................... 25

Combined Renewable Hydrogen Production Potential ............................................................ 28

Hydrogen Production Potential Summary............................................................................. 31

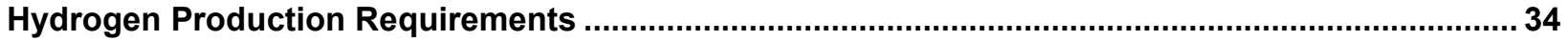

Water Resource Requirements ........................................................................... 39

Comparison of Fixed and Flow Energy Potential Estimates ............................................... 42

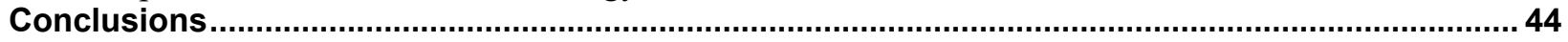

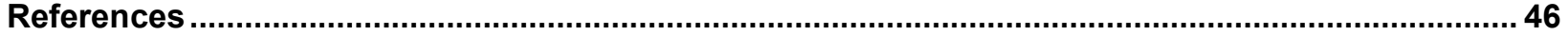

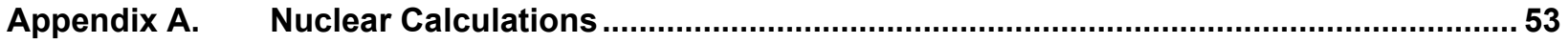

Appendix B. Water Consumption Estimates ...................................................................... 56 


\section{List of Figures}

Figure ES-1. Comparison of energy resource required to produce 10 MMT of hydrogen to current and projected energy consumption from the 2019 Annual Energy Outlook (AEO) Reference Case.

Figure 1. Domestic fossil and uranium energy reserves as a function of estimate year .............................5

Figure 2. Geographic distribution of the top 100 U.S. natural gas fields............................................... 7

Figure 3. Geographic distribution of continuous unconventional natural gas resources ........................... 8

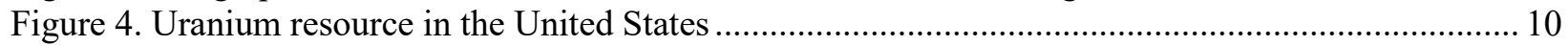

Figure 5. Renewable energy resource annual technical potentials................................................... 13

Figure 6. Hydrogen production potential from solid biomass resources, by county land area .................. 14

Figure 7. Hydrogen production potential from gaseous biomass resources, by county land area ............. 15

Figure 8. Hydrogen production potential from onshore wind resources, by county land area .................. 16

Figure 9. Hydrogen production potential from offshore wind resources, by county land area................. 17

Figure 10. Hydrogen production potential from rooftop PV, by state land area.................................... 19

Figure 11. Hydrogen production potential from utility-scale PV, by county land area ............................2 20

Figure 12. Hydrogen production potential from CSP, by county land area .......................................... 21

Figure 13. Hydrogen production potential from existing hydropower assets, by county land area............ 23

Figure 14. Hydrogen production potential from non-powered dams, by U.S. hydrologic region (HUC2)

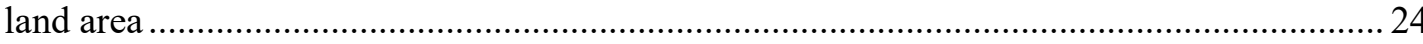

Figure 15. Hydrogen production potential from new stream-reach development, by state land area......... 25

Figure 16. Hydrogen production potential from geothermal flash and binary plants by power control area

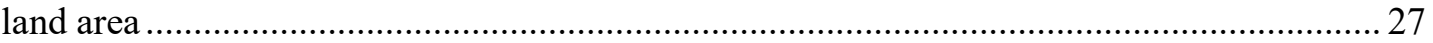

Figure 17. Hydrogen production potential from renewable resources, by county land area ....................29

Figure 18. Hydrogen production potential from dominant renewable resources, by county land area ....... 30

Figure 19. Comparison of energy resource required to produce 10 MMT hydrogen to current and projected energy consumption from the Annual Energy Outlook Reference Case (a) and Low Oil and Gas Resource and Technology scenario (b)......................................................... 38

Figure 20. Comparison of electricity demand to produce 10 MMT of hydrogen via LTE and the 2040

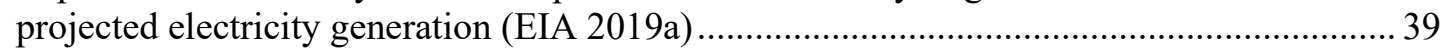

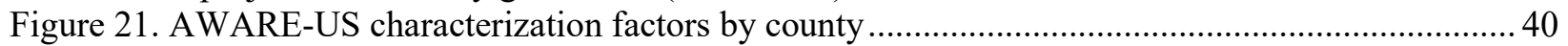

Figure 22. Comparison of direct water consumption for hydrogen production across technologies.......... 41

Figure 23. Upstream and direct water consumption by hydrogen production pathway ........................... 42

Figure A-1. Assumptions and calculations performed by Jim O'Brien for the uranium-to-hydrogen ratio

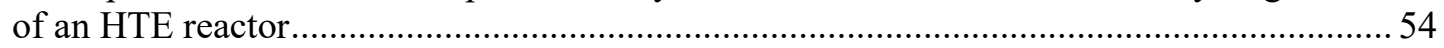




\section{List of Tables}

Table 1. Updated Assumptions and Calculations for Nuclear-Based Hydrogen Production...................... 11

Table 2. Marine and Hydrokinetics Technical Energy Resource Estimates ............................................. 22

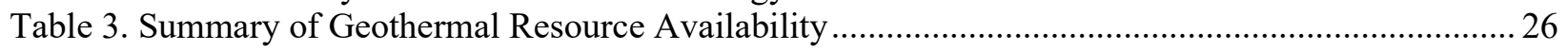

Table 4. Breakdown of Geothermal Resource by Plant Type................................................................. 26

Table 5. Amount of Renewable and Non-Renewable Resources Required to Produce $1 \mathrm{~kg}$ of Hydrogen

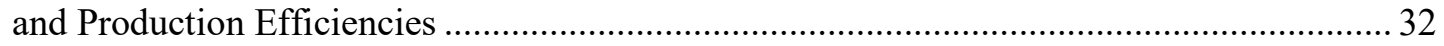

Table 6. Conversion Assumptions ................................................................................................... 33

Table 7. Availability, Current Consumption, and Projected Consumption for Fossil and Nuclear

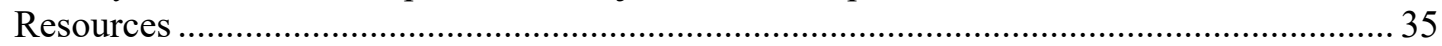

Table 8. Availability, Current Consumption, and Projected Consumption for Renewable Resources....... 36

Table 9. Hydrogen Production Potential from Finite Resources ......................................................... 43

Table 10. Annual Hydrogen Production Potential from Renewable Resources ...................................... 43

Table B-1. Direct Hydrogen Consumption of Hydrogen Production Technologies...................................56

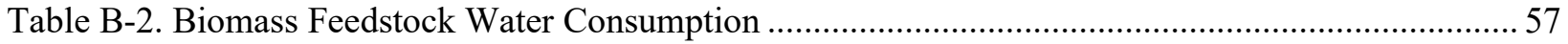

Table B-3. Upstream Water Consumption by Hydrogen Production Pathway.......................................... 58 


\section{Introduction}

The Spark M. Matsunaga Hydrogen Act of 2005 (Title VIII of the Energy Policy Act) directed the Secretary of Energy to conduct research activities "to address production of hydrogen from diverse energy resources including - fossil fuels, which may include carbon capture and sequestration; hydrogen-carrier fuels (including ethanol and methanol); renewable energy resources, including biomass; and nuclear energy." This resource assessment, by analyzing the technical potential to domestically produce hydrogen, also serves as a preliminary effort in the U.S. Department of Energy's (DOE's) H2@Scale initiative. The H2@Scale initiative brings together stakeholders to enable affordable and reliable large-scale hydrogen generation, transport, storage, and utilization in the United States across multiple sectors. The focus of this report is the compiling of modeling and analysis of domestic resources to characterize the ability of the United States to meet the potential demand for hydrogen. Though this report only explicitly considers one scenario of future demand, the results can be easily scaled to provide context for broader demand scenarios within the H2@Scale vision.

This work examines the use of diverse domestic resources to produce hydrogen, aligned with priorities for energy security, resiliency, and economic growth. This analysis considers a doubling of U.S. hydrogen demand over the next 20 years. In particular, this report examines the resource requirement to produce an additional 10 million metric tonnes (MMT) of hydrogen in 2040. This report serves as an update to the 2013 Resource Assessment for Hydrogen Production (Melaina et al. 2013), henceforth referred to as the 2013 Resource Report. This report maintains the following objectives of the 2013 Resource Report:

- Estimate total hydrogen production potential for multiple energy resources.

- Estimate the quantity of domestic energy resources required to meet an incremental increase in hydrogen demand in the future, of 10 MMT of hydrogen annually, and compare those requirements to the projected future consumption of each resource.

While the 2013 Resource Report focused on potential increased demand in hydrogen from fuel cell electric vehicles (FCEVs), this report acknowledges the variety of end-use applications that could lead to an increase in hydrogen demand. Ten million metric tonnes of hydrogen, as described in the 2013 Resource Report, could meet the demand of 50 million FCEVs, though this amount of hydrogen could also be used to meet future demand for synthetic fuels production, ammonia production, metals refining, and seasonal energy storage, among others.

The technical potential of natural gas, coal, uranium, biomass, wind, and solar resources have been updated in the present report. In addition, this report includes the technical potential from water power and geothermal resources. This report considers the same hydrogen production pathways from the H2A case studies (DOE 2012) as described in the 2013 Resource Report (e.g., steam methane reforming, coal gasification, nuclear high-temperature electrolysis, biomass gasification, and electrolysis).

This assessment relies on the best available data for resource technical potential. Technical potential refers to technology-specific estimates of energy generation potential based on resource availability and quality, technical system performance, topographic limitations, and environmental and land-use constraints. Technical potential should not account for economic or 
market constraints, though economics may be inherent in certain data sets (e.g., uranium reserves). A number of data sources were used to represent technical potential by energy resource, and thus there are some inconsistencies in the methodologies and underlying data. The purpose of this assessment is to leverage and aggregate existing analyses to calculate hydrogen production potential.

The previous analysis was updated with the following modifications to assumptions and methodology:

- This update does not introduce any policy implications. It focuses on a technical potential analysis that will help guide future R\&D needs based on affordability, type of resource, and regional variations. For example, in certain regions, the availability of low-cost wind and otherwise curtailed wind could drive an opportunity for affordable hydrogen production.

- This analysis only reports on technical potential. Economic potential analysis is outside the scope of the current work.

- The 2019 Annual Energy Outlook (AEO2019) Reference Case is used to update the projected energy demand for each resource (EIA 2019a).

- The AEO2019 Low Oil and Gas Resource and Technology scenario is used as an alternative to the Reference Case to represent a future in which high prices of oil and gas may impact the future consumption of alternative fuels produced from diverse feedstock (EIA 2019a).

- The production efficiency of coal gasification is increased to 53.3\% (lower heating value [LHV]), based on the National Energy Technology Laboratory (NETL 2010) coal case 2.2 .

- The higher heating value of natural gas is increased to 1,036 British thermal units per standard cubic foot (Btu/scf) (EIA 2019b).

- The burnup rate for nuclear power generation is updated to 60 gigawatt-days thermal per metric tonne of uranium (GWdt/tonne U) (O'Brien 2017), based on high-temperature gas-cooled reactor technology, from $45 \mathrm{GWdt} /$ tonne $\mathrm{U}$, which was based on historical data of light-water reactors in the United States. Thus the amount of uranium required to produce $1 \mathrm{~kg}$ of hydrogen is reduced to $4.62 \times 10^{-5} \mathrm{~kg}$ U for high-temperature electrolysis. ${ }^{6}$

- Projections from the 2016 Billion-Ton Report (DOE 2016) are used to update the technical potential from solid biomass. The map of hydrogen production potential is updated based on forestry resources, agricultural residues, and energy crops.

- Recent geospatial analysis (Milbrandt et al. 2018) is used, in place of waste resources estimated in the Billion-Ton Report (DOE 2016), to estimate the potential from biogas resources. The estimate and corresponding map of hydrogen potential from gaseous biomass has been updated.

\footnotetext{
${ }^{6}$ Due to lack of updated data and models, this report does not include the thermochemical nulear pathway for hydrogen production that was analyzed in the 2013 Resource Report.
} 
- The production efficiency of low temperature electrolysis is updated to $64.9 \%$ (LHV) based on the H2A Future Central Hydrogen Production from Polymer Electrolyte Membrane (PEM) Electrolysis model. ${ }^{7}$

- The NREL reV model (Maclaurin et al. 2019) results have been used to update the landbased wind resource and map.

- The offshore wind potential has been updated to be consistent with Musial et al. (2016).

- The NREL reV model (Maclaurin et al. 2019) is used to update the technical potential and resource map for the utility-scale photovoltaics (PV).

- Rooftop PV technical potential has been updated according to Murphy et al. (2019).

- Two additional renewable resources have been included in this study: water power and geothermal.

The first section of this report focuses on fossil and nuclear resource availability. The following section assesses renewable energy resource availability. Table 6 (presented on page 33) provides a summary of the assumed conversion efficiencies for each resource. The hydrogen requirement corresponding to a possible future demand scenario that doubles current production (i.e., an additional 10 MMT of hydrogen) is assessed with respect to the ability of each single resource to meet $10 \mathrm{MMT}$ of hydrogen demand. More detailed discussions of resource issues related to the assessment approach and results can be found in the 2013 Resource Report, as well as other earlier studies (Milbrandt and Mann 2007; 2009).

${ }^{7}$ Based on DOE Hydrogen and Fuel Cells Program Record 19009 (DOE 2020). 


\section{Estimates for Fossil Fuel and Nuclear Resources}

Reserve estimates from the U.S. Energy Information Administration (EIA) are used to approximate the technical potential of fossil and uranium resources. These estimates are uncertain and are likely to increase as technology develops, industry practices improve, and the understanding of the geology increases. However, these estimates are currently the best available data to represent technical resource potential.

The reserve estimates for coal, natural gas, and uranium are summarized on an equivalent thermal energy basis (quadrillion British thermal units [Btu] [quads], higher heating value [HHV]) in Figure 1. ${ }^{8}$ The updates to Figure 1, a version of which was published in the 2013 Resource Report, are based on recent EIA data on coal reserves from the EIA Annual Coal reports (EIA 2019c, Table 15), 2015 natural gas reserves (EIA 2017b; EIA 2018a; EIA 2018b; EIA 2020a), and uranium reserves (EIA 2017c; EIA 2018c). Comparing on an equivalent thermal energy basis indicates that coal resources have the highest technical potential, followed by natural gas and then uranium. However, there is significant uncertainty in the uranium resource estimates that will be described in the following sections.

The demonstrated reserve base, from the EIA's Annual Coal Reports, is used to represent the technical resource potential of coal. The demonstrated reserve base shows a downward trend from 2001 to 2018, decreasing from approximately 500 to 475 billion tons of coal. This is converted to quads using the approximate heat content from coal (EIA 2020c), which decreases from 10,300 to 9,500 quads.

The combined proved and unproved natural gas reserves constitute the total technically recoverable resource. The estimates of total technically recoverable natural gas have varied over time though have generally trended upward since 2006. The dotted line indicates missing data from the EIA Annual Energy Outlook Assumptions Reports. The most recent reports estimate the total technically recoverable natural gas at approximately 2,500 quads.

Uranium reserves are presented at the highest price point for which data is available, $\leq \$ 100 / \mathrm{lb}$ $\mathrm{U}_{3} \mathrm{O}_{8}$. The 2009 reserves estimate, as reported in the 2013 Resource Report, is significantly higher than the reserves reported between 2012 and 2018 due to differences in the data set used by the EIA for reserve estimates (EIA 2017c). The more recent reserve estimates range between 300 and 360 million pounds of $\mathrm{U}_{3} \mathrm{O}_{8}$ (575 to 690 quads).

While these classification systems are defined with different approaches by resource type, they are used here as general estimates for the technical energy resource potentials. The following sections provide additional information on resource potentials and conversion rates used for determining hydrogen production potentials. Detailed descriptions of fossil and uranium reserve and resource categories are summarized in the 2013 Resource Report (Melaina et al. 2013, Table 1). This assessment uses the same classifications of resource technical potential for coal (demonstrated reserve base), natural gas (proved and unproved reserves), and uranium (reasonably assured resource estimates at $<\$ 100 / \mathrm{lb} \mathrm{U}_{3} \mathrm{O}_{8}$ ) as the 2013 Resource Report.

\footnotetext{
${ }^{8}$ Comparing on a thermal energy basis (HHV) is chosen to maintain consistency with the 2013 Resource Report as
} well as how the EIA compares and aggregates data from different energy sources. 


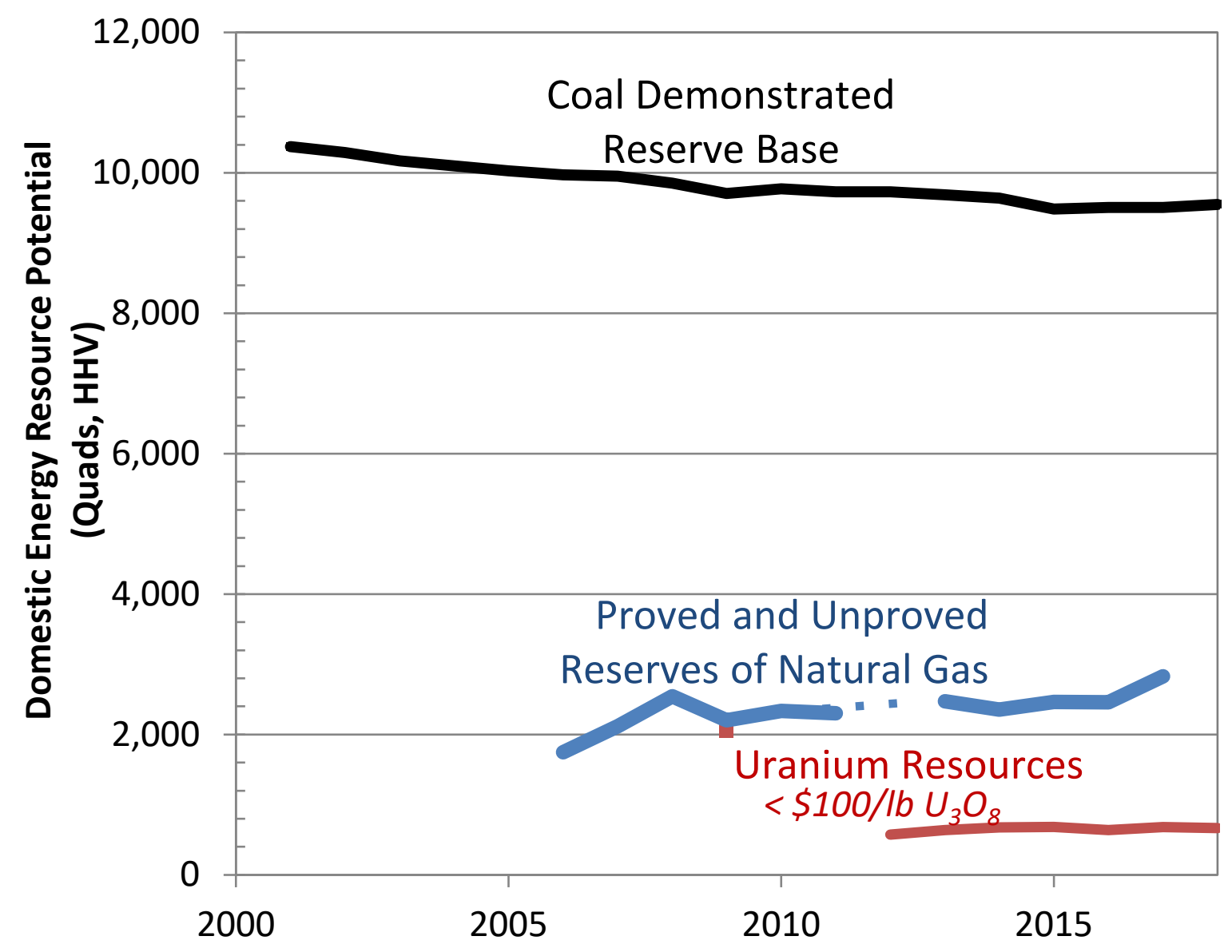

Figure 1. Domestic fossil and uranium energy reserves as a function of estimate year

Sources: Melaina et al. 2013; EIA 2016; EIA 2017a-c; EIA 2018 a-c, EIA 2020a

\section{Coal Resources}

Similar to the 2013 Resource Report, the present update uses the EIA's estimates of Demonstrated Reserve Base (DRB) to represent the technical potential of coal reserves. The DRB of coal in 2018 is reported to be approximately 474 billion short tons (EIA 2019b). The "Western region" of the United States, most notably Wyoming, Montana, and Illinois, accounts for nearly $60 \%$ of total coal (EIA 2019b). To convert from tons to thermal energy equivalents, we use EIA's reported HHV of produced coal, 20.16 million Btu/short ton in 2018 (EIA 2020c). The result is a technical potential of approximately 9,550 quads in 2018 (see Figure 1).

In 2010, the National Energy Technology Laboratory (NETL) assessed hydrogen production from coal assuming a specific bituminous coal gasification technology (NETL 2010). Case 2-2 from the NETL (2010) report is the basis for the H2A Central Coal case study (DOE 2019). The H2A Central Coal case study (see DOE [2012]) was recently updated based on a case study by NETL (NETL 2010). This report uses the NETL case study as the basis for the coal-to-hydrogen pathway, specifically with respect to the amount of coal needed to produce a kilogram of 
hydrogen. ${ }^{9}$ This differs slightly from what has previously been assumed in the H2A case study, where the amount of coal needed for hydrogen production is scaled by energy content and applied to the coal mix used for electricity production, implying this coal mix is suitable for the modeled hydrogen production technology. The assumption in this report is based on expert feedback and addresses the issue that the specific gasification technology assessed in the NETL study is not suitable for all coal types (for example, those that cannot be slurry fed). Other gasification technologies can be used for different coal types, and future analysis should address the efficiency of hydrogen production via these other gasification technologies.

\section{Natural Gas Resources}

In 2020, the EIA (EIA 2020a) reported that at the end of 2017, the technically recoverable U.S. dry natural gas resources totaled 2,829 trillion cubic feet (Tcf), comprising 439 Tcf of proved natural gas reserves and 2,390 Tcf of unproved natural gas resources. Using the EIA report HHV of 1,036 Btu/scf for dry natural gas produced in 2017 (EIA 2020b), we calculate the thermal energy equivalent of the technical potential of natural gas to be 2,550 quads. Figure 1 shows the historical changes in technically recoverable U.S natural gas resource estimates over time. Technically recoverable natural gas resources are the amount that can be produced using current recovery technology but without reference to economic profitability.

These EIA estimates of proved and unproved depend, in part, on data from the United States Geological Survey (USGS). Figure 3 summarizes the geographic distribution of continuous unconventional (such shale and coalbed) gas based on 2000-2018 assessments of unproved reserves (USGS 2020). As shown in the map, the largest continuous unconventional gas deposit (disperse with diffuse boundaries) in the United States occurs in the Gulf Coast Mesozoic deposit. The geographic distribution of the top 100 U.S. natural gas fields by proved reserves (as of December 31, 2013) is shown in Figure 2. As of 2009, the Marcellus Shale Area, in West Virginia and Pennsylvania, has been identified as the largest U.S. gas field based on estimated proved reserves (EIA 2015).

\footnotetext{
${ }^{9}$ When estimating hydrogen production potential from coal reserves, the implicit assumption is that other coal gasification technologies will be able to match the coal-to-hydrogen conversion rate described in the NETL case study. Additional analysis is needed to refine this assumption.
} 


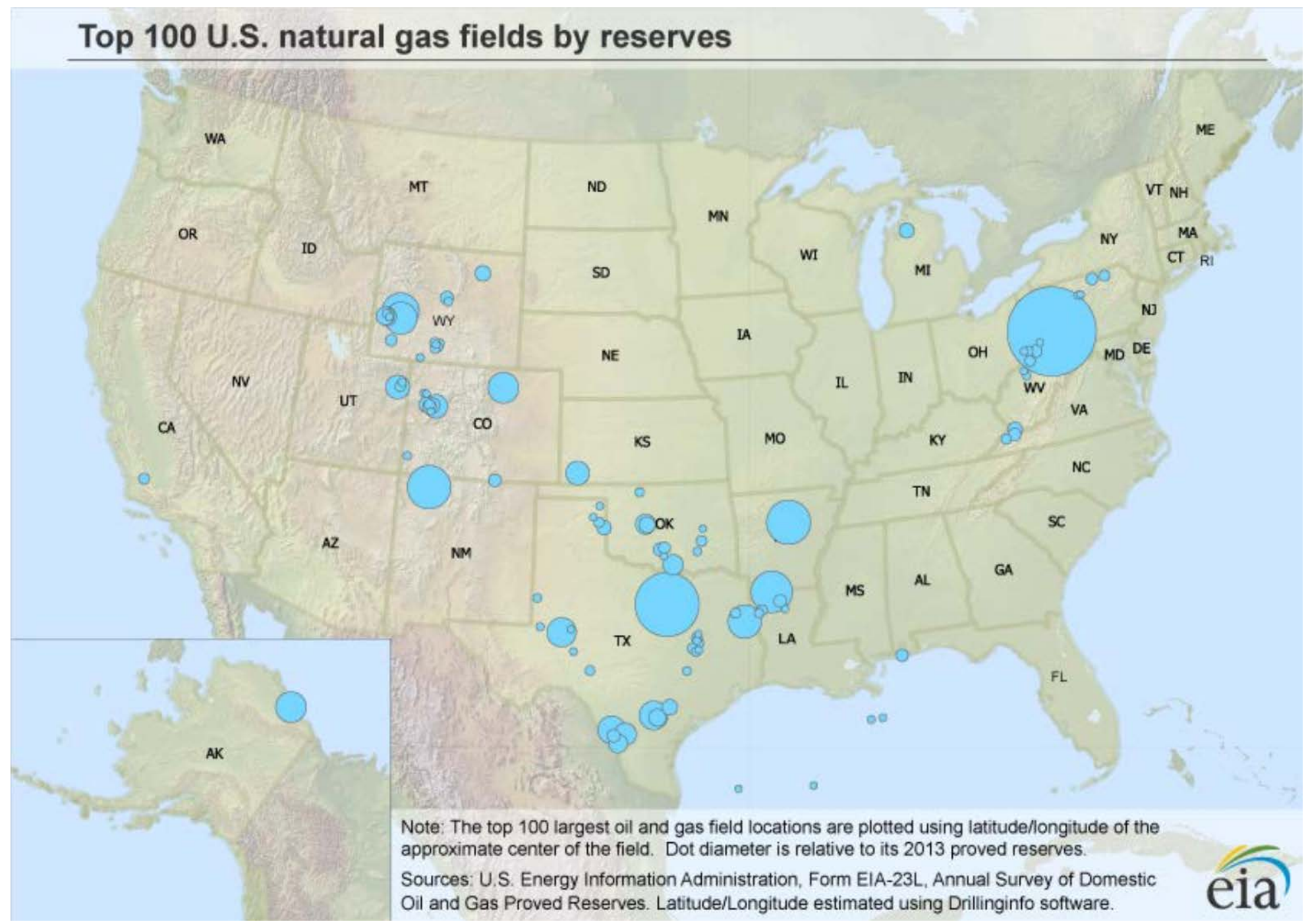

Figure 2. Geographic distribution of the top 100 U.S. natural gas fields

Source: EIA 2015 


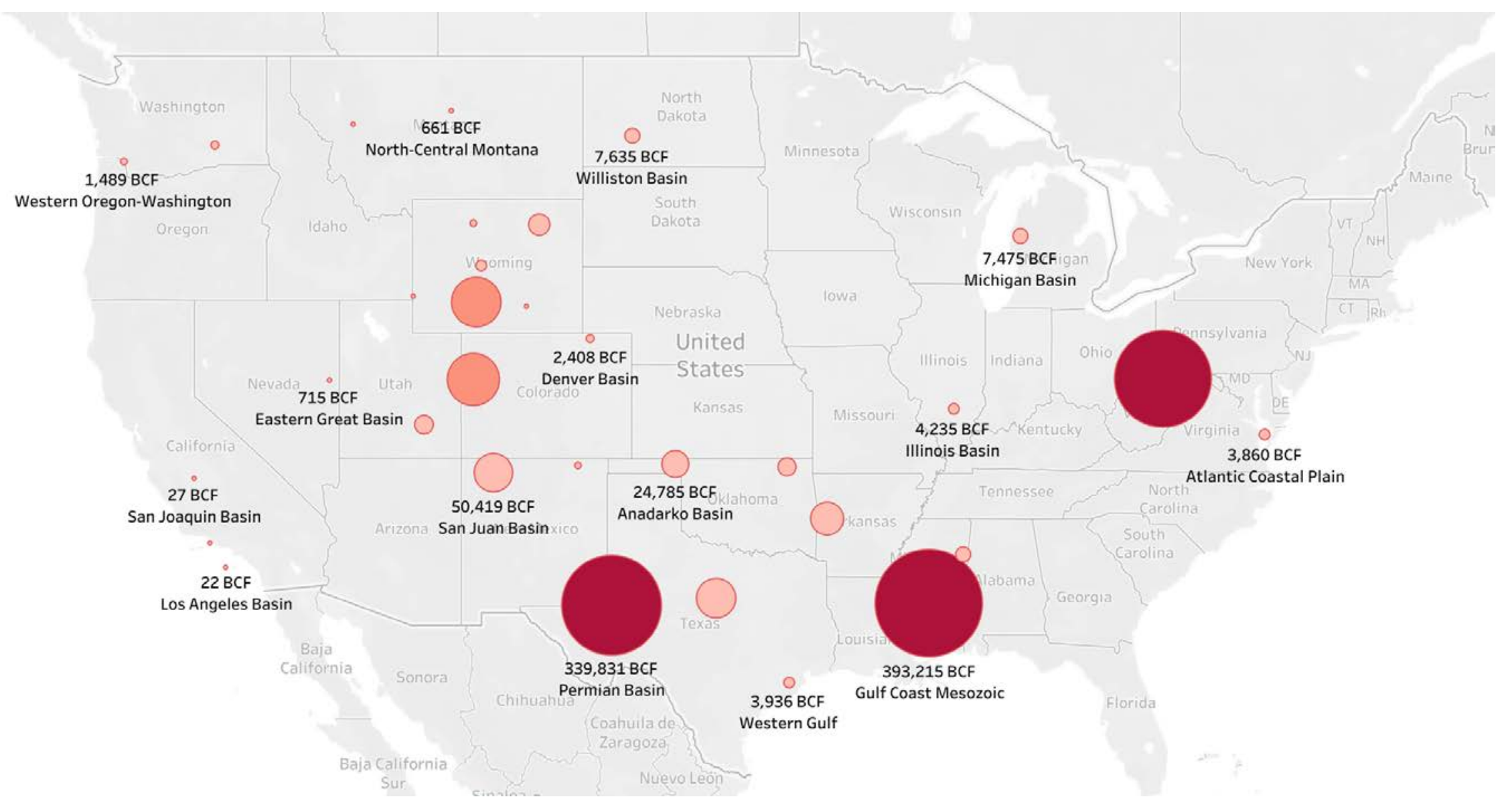

Figure 3. Geographic distribution of continuous unconventional natural gas resources

Source: USGS 2020 


\section{Uranium Resources}

The EIA reports uranium reserves in units of millions of pounds of uranium oxide $\left(\mathrm{U}_{3} \mathrm{O}_{8}\right)$, where there is $0.848 \mathrm{~kg} \mathrm{U}$ (contained uranium) per $1 \mathrm{~kg} \mathrm{U}_{3} \mathrm{O}_{8}$ (NEA-IAEA 2018, Appendix 3). In addition, the EIA reports on uranium reserves in terms of forward costs for production, ${ }^{10}$ with the highest cost threshold at $\leq \$ 100 / 1 \mathrm{~b} \mathrm{U}_{3} \mathrm{O}_{8}$. The EIA uranium reserve estimate at the end of 2018 is 353.2 million pounds $\mathrm{U}_{3} \mathrm{O}_{8}$ at $\leq \$ 100 / \mathrm{lb}$ (EIA 2019c, Table 10). In recent years, the weighted average price of U.S. uranium has fallen from a peak of $\$ 59.44 / 1 b \mathrm{U}_{3} \mathrm{O}_{8}$ in 2012 to below \$50/lb U $\mathrm{O}_{8}-\$ 45.26 / \mathrm{lb} \mathrm{U}_{3} \mathrm{O}_{8}$ in 2018 (EIA 2019d, Table S1b). Consistent with the 2013 Resource Report, we use the $\$ 100 / \mathrm{lb}$ cost category as the estimate for uranium technical potential, given a lack of other resource (e.g., inferred) estimates.

There are major uncertainties associated with U.S. uranium resource estimates, and a thorough evaluation of the U.S. uranium resource base has not been conducted since 1980 (NEA-IAEA 2016). The USGS is currently re-estimating undiscovered uranium resources in the United States, which will provide a theoretical potential for uranium resources as probabilistic estimates without an associated cost category (NEA-IAEA 2016). The current EIA survey of uranium reserves covers a much smaller set of properties than were covered previously, though the "EIA believes that within its scope the EIA-851A data proves more reliable estimates of the uranium recoverable at the specified forward costs than the estimates derived from 1974 through 2002" (EIA 2017c, page 2). The 2016 Uranium Report by the Nuclear Energy Agency and the International Atomic Energy Agency (NEA-IAEA 2016) provides estimates on uranium reserves by country and price. The results for the United States are similar to those published by the EIA and suffer the same limitation posed by a reduced number of mines and properties providing reserve estimates (NEA-IAEA 2016, Table 1.5). Inferred resources can be estimated using geological evidence and sampling data. The United States has not historically reported on inferred uranium resources; however, it is estimated that uranium technical resource potential might increase by $10 \%$ if inferred resources were added to reasonably assured resources (RAR) (NEA-IAEA 2016).

Of the RAR estimate at $<\$ 100 / \mathrm{lb} \mathrm{U}_{3} \mathrm{O}_{8}$, about $45 \%$ of this technical potential (160 million lb $\mathrm{U}_{3} \mathrm{O}_{8}$ ) was reported as being located in Arizona, New Mexico, and Utah at the end of 2017 (EIA 2019c, Table 10). Figure 4 shows a map of U.S. uranium resources from the USGS (2017). The total estimated technical potential represents only $1 \%$ of total global identified uranium resources (NEA-IAEA 2016, Figure 1.1). Foreign imports of uranium to the United States have been increasing over time and constituted $90 \%$ of uranium purchased by owners and operators of U.S. civilian nuclear power reactors in 2018 (EIA 2019d, Table 2). We restrict our analysis to domestic resources, however, for consistency with estimates for other resource types.

\footnotetext{
10 The EIA describes forward costs as including "the costs for power and fuel, labor, materials, insurance, severance and ad valorem taxes, and applicable administrative costs. The forward costs used to estimate U.S. uranium ore reserves are independent of the price at which uranium produced from the estimated reserves might be sold in the commercial market."
} 


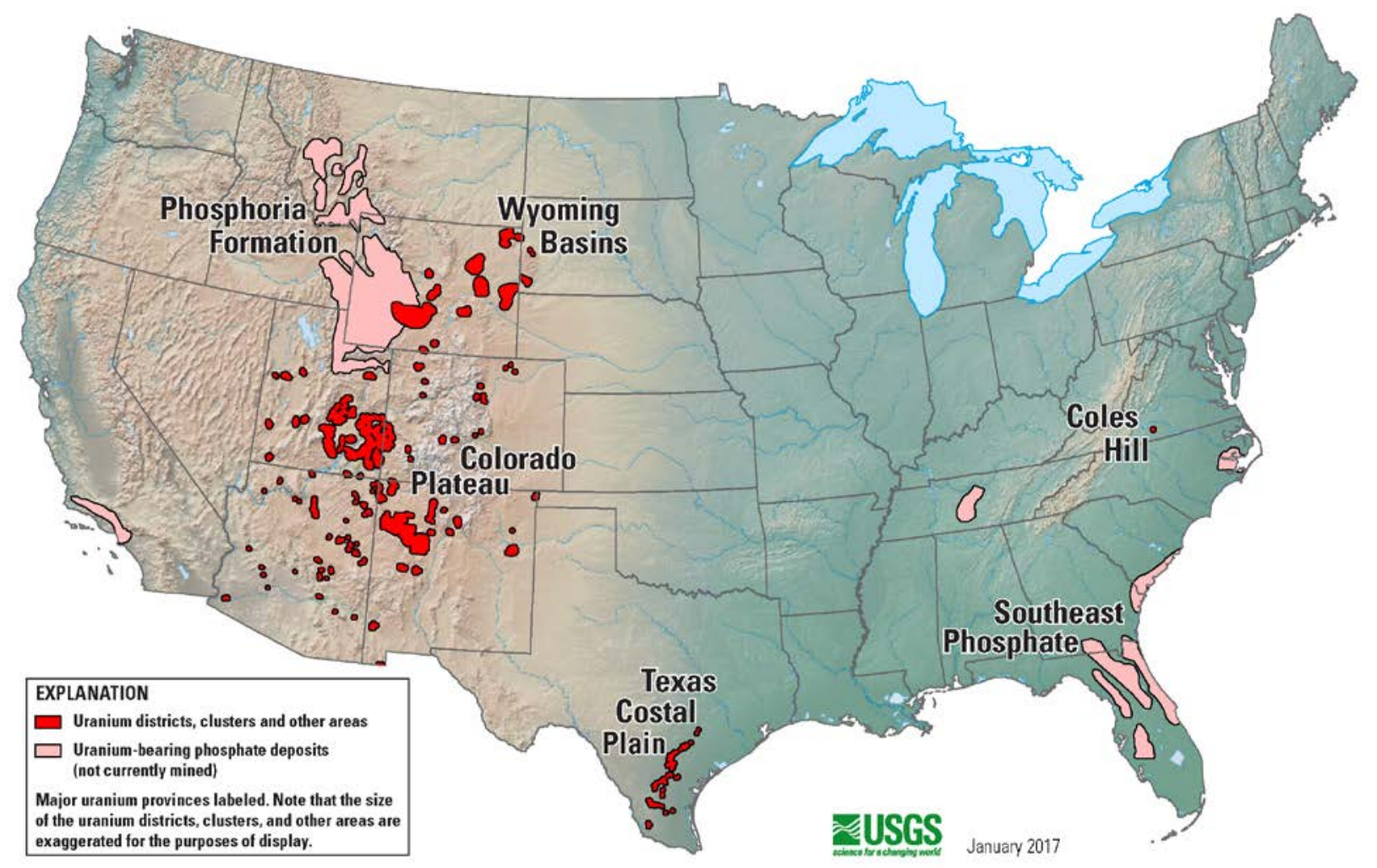

Figure 4. Uranium resource in the United States

Source: USGS 2017

To determine uranium resource consumption for future electricity generation, a nominal burnup rate of 60 gigawatt-days thermal per metric tonne of uranium (GWdt/tonne $\mathrm{U}$ ) is assumed, based on high-temperature gas-cooled reactor technology (O'Brien 2017). This is an update to the previously assumed $45 \mathrm{GWdt} /$ tonne U used in the 2013 Resource Report, which was estimated as the historical average from U.S. light-water reactors. The assumed hydrogen production rate from a $600 \mathrm{MW}$-thermal $(\mathrm{MWt})$ nuclear power plant ${ }^{11}$ coupled with high-temperature electrolysis (HTE) has been increased from 78 to 85 million cubic feet per day for this update, based on recent system modeling results from Idaho National Laboratory (O'Brien 2017, see Appendix A) of a high-temperature gas-cooled reactor. ${ }^{12}$ Table 1 summarizes updates to the assumptions for nuclear hydrogen production and the resulting updates to calculated values used for determining resource potential. Further details on calculations are provided in Appendix A.

\footnotetext{
${ }^{11} 600 \mathrm{MWt}$ is significantly smaller than currently operating U.S. light-water reactors but was chosen to maintain consistency with the 2013 Resource Report assumptions and Idaho National Laboratory modeling of relatively small, modular high-temperature gas-cooled reactors (O’Brien 2014; O’Brien 2017).

${ }^{12}$ High-temperature gas-cooled reactor (HTGR) technology is commercially available though not currently economical. HTGRs achieve higher fuel utilization rates and and operate at higher temperatures than current lightwater reactors do.
} 
Table 1. Updated Assumptions and Calculations for Nuclear-Based Hydrogen Production

\begin{tabular}{|c|c|c|c|}
\hline \multicolumn{2}{|l|}{ Assumptions } & $\begin{array}{l}2013 \text { Resource } \\
\text { Report }\end{array}$ & $\begin{array}{l}\text { Update/Current } \\
\text { Report }\end{array}$ \\
\hline \multicolumn{2}{|l|}{ Nominal burnup rate } & $45 \mathrm{GWdt} /$ tonne U & $60 \mathrm{GWdt} /$ tonne U \\
\hline \multicolumn{2}{|l|}{ Hydrogen production rate } & 78 million $\mathrm{ft}^{3} \mathrm{H}_{2} /$ day & 85 million $\mathrm{ft}^{3} \mathrm{H}_{2} /$ day \\
\hline \multicolumn{2}{|l|}{ Plant capacity } & $600 \mathrm{MW}$ & $600 \mathrm{MW}$ \\
\hline Calculated parameters & Formula & & \\
\hline $\begin{array}{l}\text { Production efficiency } \\
\text { (LHV) }\end{array}$ & $\begin{array}{l}\text { Hydrogen production rate }{ }^{*} \mathrm{H}_{2} \\
\text { energy density (LHV) / plant } \\
\text { capacity }\end{array}$ & $46.0 \%$ & $50.2 \%$ \\
\hline $\begin{array}{l}\text { Uranium-to-hydrogen } \\
\text { ratio }\end{array}$ & $\begin{array}{l}\text { Uranium burn rate / hydrogen } \\
\text { production rate, } \\
\text { where the uranium burn rate }= \\
\text { nominal burnup rate * } \\
\text { production efficiency / } \mathrm{H}_{2} \\
\text { energy density }\end{array}$ & $\begin{array}{l}6.71 * 10^{-5} \mathrm{~kg} \mathrm{U} / \mathrm{kg} \\
\mathrm{H}_{2}\end{array}$ & $\begin{array}{l}4.62 * 10^{-5} \mathrm{~kg} \mathrm{U} / \mathrm{kg} \\
\mathrm{H}_{2}\end{array}$ \\
\hline
\end{tabular}

A heat rate of $10,459 \mathrm{Btu} / \mathrm{kWh}(32.6 \%$ thermal efficiency) is assumed based upon the average heat rates reported by EIA from 2008 to 2018 (EIA 2019e, Table 8.1). The result is approximately $398,385 \mathrm{kWh}$ of electricity generated per $\mathrm{kg}$ of $\mathrm{U}_{3} \mathrm{O}_{8}$. Consistent with the methodology used in the 2013 Resource Report, projected resource demands are expressed in terms of nuclear electricity generation (EIA 2019a) and calculated using the heat rate from EIA (2019e). The uranium-to-hydrogen ratios listed in Table 1 are used in determining technical hydrogen potential (as shown in Table 9).

The uranium resource and hydrogen production potential from nuclear estimates presented here are likely conservative for several reasons. As previously mentioned, the U.S. estimates of uranium reserves have not been througoughly evaluated since 1980, and current resource data is only estimated for cost thresholds up to $\$ 100 / 1 b \mathrm{U}_{3} \mathrm{O}_{8}$. In addition, new ore processing and fuel fabrication techniques may lead to increases in RAR. Nuclear energy resources could also be increased by reprocessing of spent uranium fuel because the spent fuel retains about $96 \%$ of the fissile material from the original fuel (NEA-IAEA 2016). Further, the United States is involved in international efforts (e.g., the Generation IV International Forum) to develop advanced reactor technologies, which would improve the efficiency of uranium use while potentially providing heat for hydrogen production (NEA-IAEA 2016, pages 123-124). ${ }^{13}$

\footnotetext{
${ }^{13}$ Mined uranium (U) is only about $0.7 \%$ fissile U235, where the majority is U238 which is not utilized but fertile. Advanced reactor designs can lead to increased utilization of U235 and greater conversion and use of U238.
} 


\section{Estimates for Renewable Resources}

We use data from various DOE and national laboratory analyses to estimate the technical potential for producing hydrogen from the following renewable energy resources: biomass, wind, solar, water power, and geothermal. The technical potential estimates for these renewable resources are summarized on an equivalent thermal energy basis (quads, HHV) in Figure 5. In order to make these values comparable to the fossil and nuclear resources presented in the previous section, the quads of annual generation is presented in thermal equivalents assuming 9,268 Btu/kWh based on the 2017 approximate fossil fuel heat rates for electricity net generation (EIA 2019f).

A brief description of the resource analysis is provided in the sections below for each technology used to harness these renewable energy resources. The technical potential for producing hydrogen from solid biomass and biogas has been updated with more recent data. Both the wind and solar resources, and corresponding technical potential for producing hydrogen, have also been updated. In addition, this report includes technical resource potential estimates for water power and geothermal.

This report maintains the following characterizations of renewable technical potential estimates from Lopez et al. (2012):

"These are technology-specific estimates of energy generation potential based on renewable resource availability and quality, technical system performance, topographic limitations, environmental, and land-use constraints only. The estimates do not consider (in most cases) economic or market constraints, and therefore do not represent a level of renewable generation that might actually be deployed."

(Lopez et al. 2012, p. iv)

"Note that as a technical potential, rather than economic or market potential, these estimates do not consider availability of transmission infrastructure, costs, reliability or time-of-dispatch, current or future electricity loads, or relevant policies. Further, as this analysis does not allocate land for use by a particular technology, the same land area may be the basis for estimates of multiple technologies (i.e., non-excluded land is assumed to be available to support development of more than one technology). Finally, since technical potential estimates are based in part on technology system performance, as these technologies evolve, their technical potential may also change."

(Lopez et al. 2012, p. 2)

This report aggregates previous analyses on resource technical potential by technology. As such, one limitation of this assessment is that there may be inconsistencies in the calculation of technical potential across resoources and technologies. For further details on the calculation of resource technical potential by technology, please refer to the cited references for each resource.

Unlike the 2013 Resource Report, the current report does not include estimates of economic potential. The economic production of hydrogen from various resources will be explored in future H2@Scale analysis. 


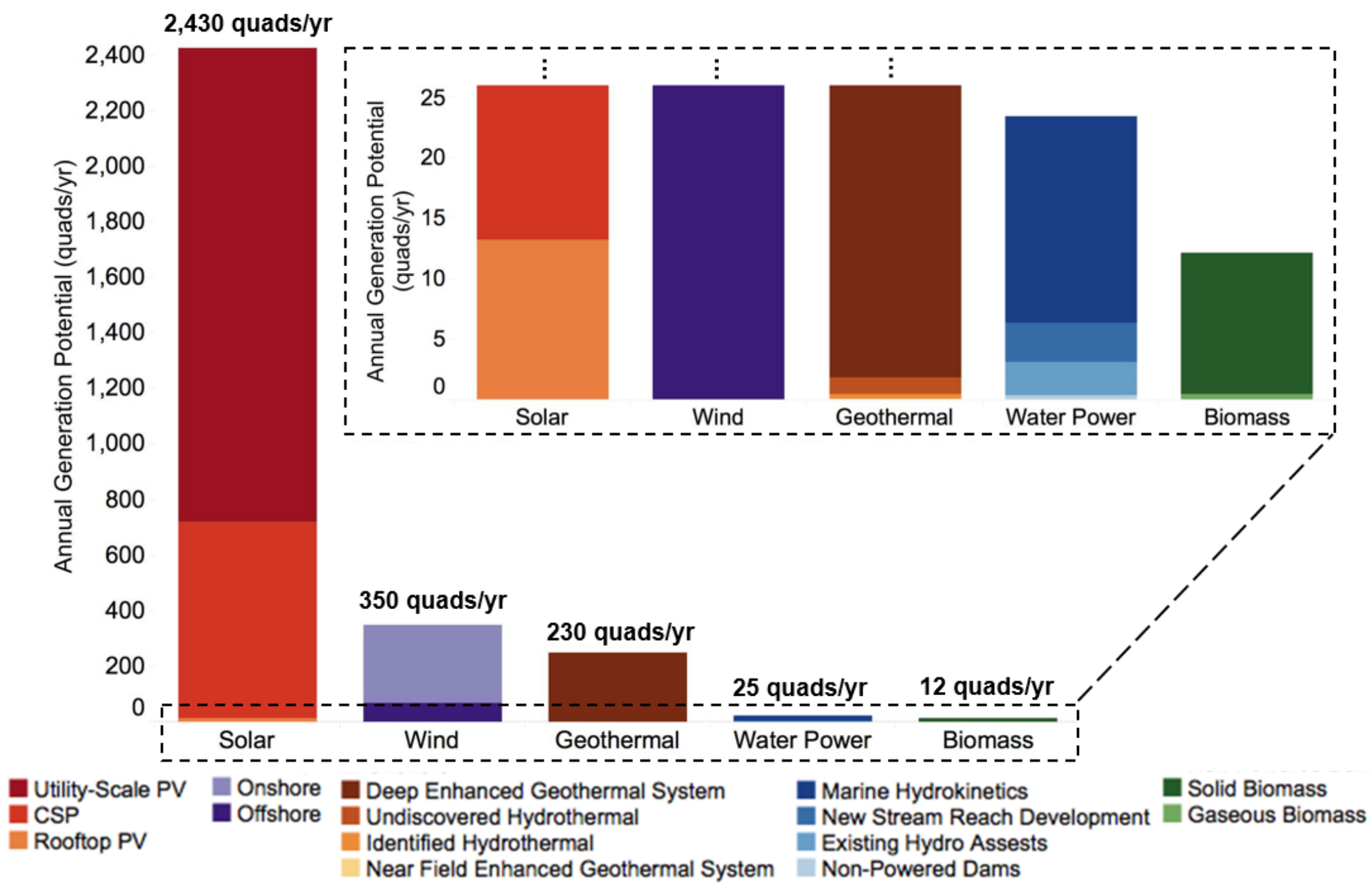

Figure 5. Renewable energy resource annual technical potentials

Note: For solar, wind, geothermal, and water power the quads of annual generation is presented in thermal equivalents assuming 9,268 Btu/kWh, based on the 2017 approximate fossil fuel heat rates for electricity net generation (EIA 2019f). The assumptions on high heating values used for solid biomass and biomethane are given in Table 6 . 


\section{Biomass Resources}

For this study, we calculate the technical potential for biomass resources as the combination of solid biomass resources from the 2016 Billion-Ton Report (DOE 2016) and gaseous biomass resources from recent NREL analysis (Milbrandt et al. 2018). The baseline projections, of forestry resources, agricultural residues, and energy crops, out to 2040 result in 684 million dry tons of biomass. Using the H2A future biomass case study (Mann and Steward 2018) conversion rate of $13 \mathrm{~kg}$ bone-dry biomass per $\mathrm{kg}$ hydrogen, the hydrogen production potential from solid biomass is estimated at 48 MMT per year. Figure 6 shows the geographic distribution of the hydrogen production potential from solid biomass resources.

It is estimated that about 11 million tons of biomethane are generated per year in the United States, converting to approximately 3 MMT of hydrogen per year (Milbrandt et al. 2018; Saur and Milbrandt 2014). The feedstocks included in this estimate are animal maure, wastewater sludge, food waste, and fats, oils, and greases. Figure 7 shows the geographic distribution of the hydrogen production potential from biogas resources.

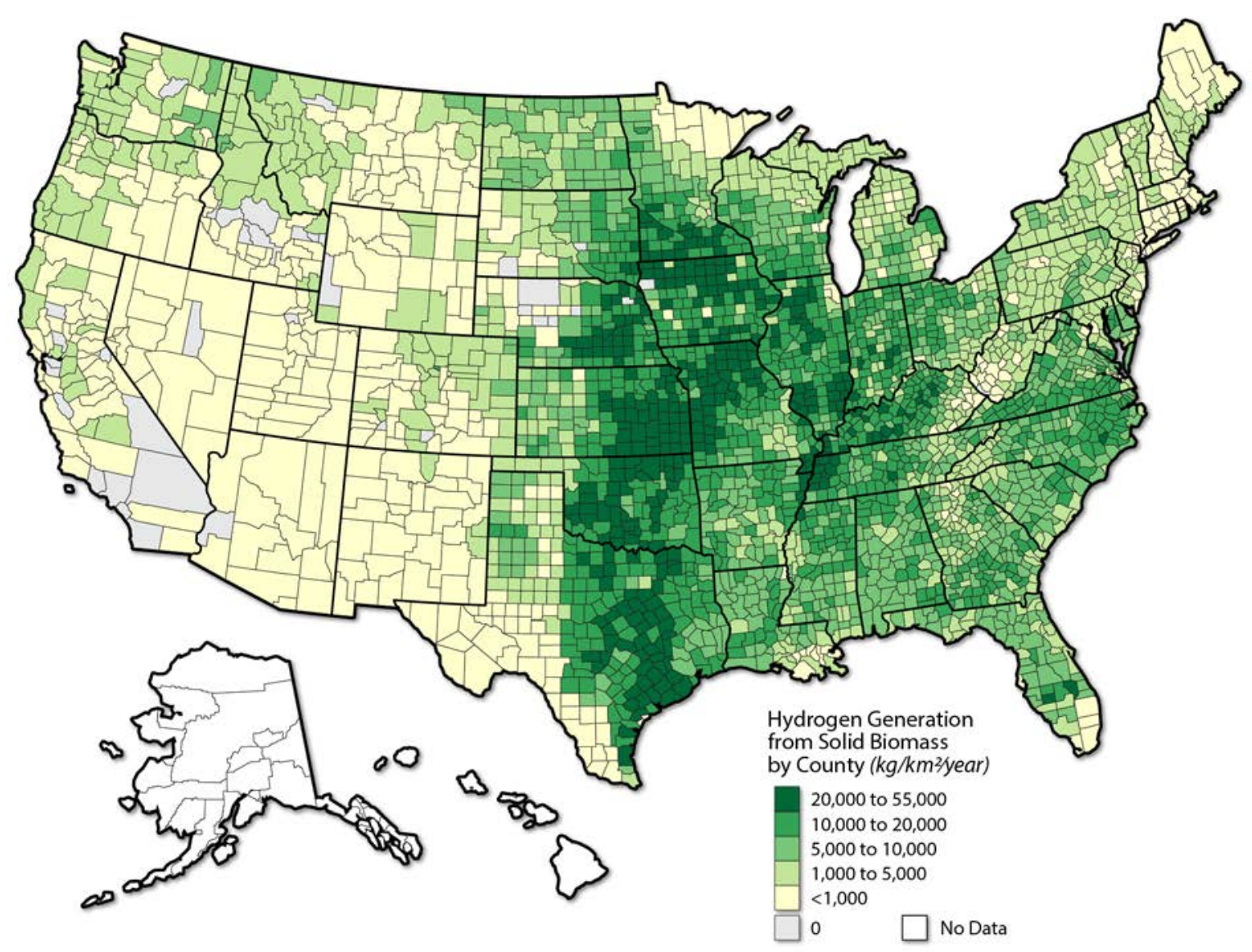

Figure 6. Hydrogen production potential from solid biomass resources, by county land area 


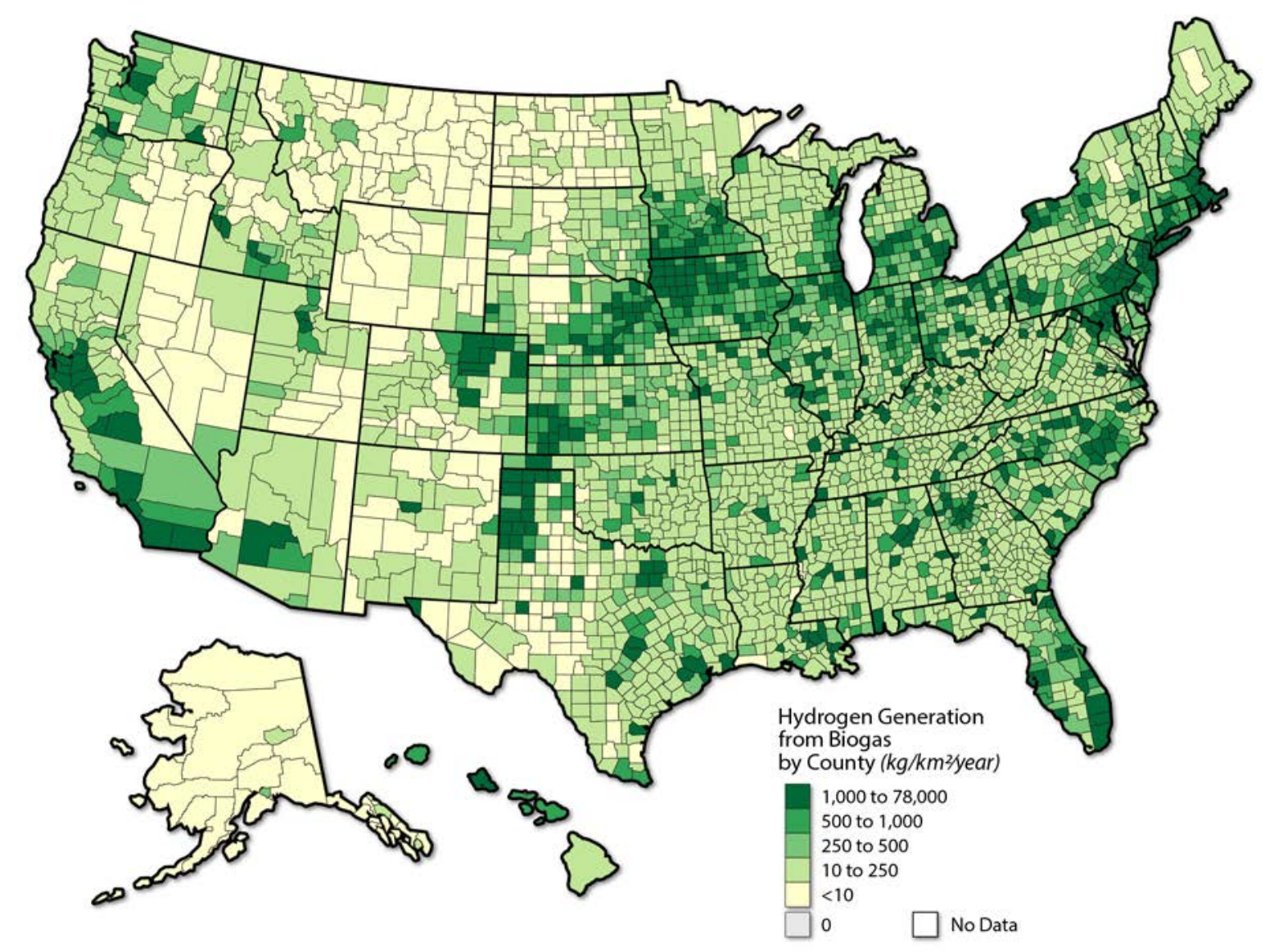

Figure 7. Hydrogen production potential from gaseous biomass resources, by county land area

\section{Wind Resources}

The technical potential for land-based wind resources comes from NREL's Renewable Energy Potential (reV) model (Maclaurin et al. 2019) and is estimated at approximately 30,500 TWh of generation per year. This updated estimate is about 7\% lower than the 32,700 TWh assumed as the technical potential in the 2013 Resource Report (from Lopez et al. 2012). Land-based wind spatial exclusions are detailed in Table C-1 of Maclaurin et al. (2019).

The reV model does not include estimates for the technical potential of offshore wind; as such, the 2016 Offshore Wind Energy Resource Assessment (Musial et al. 2016) is used as the most current source on technical potential. ${ }^{14}$ The updated offshore wind technical potential is approximately 7,200 TWh of generation per year, $60 \%$ lower than the estimate from Lopez et al. (2012). The offshore wind estimate reported in the 2013 Resource Report was cited as likely being an overestimate because it did not include an exhaustive set of exclusions. In this estimate of technical potential, technology exclusions were based on maximum water depth for deployment, minimum wind speed, and limits to floating technology in freshwater surface ice (see Musial et al. 2016 for more details).

\footnotetext{
${ }^{14}$ Both offshore and land-based technical potential estimates are expected to be updated in 2020.
} 
The combined technical potential generation from wind resources is 38,000 TWh per year. Assuming a hydrogen production power requirement of $51.3 \mathrm{kWh}$ per $\mathrm{kg}$ of hydrogen for water electrolysis (see Table 5), this translates to a technical hydrogen production potential of 700 MMT hydrogen per year. The geographic distribution of land-based and offshore wind resources is indicated in Figure 8 and Figure 9, respectively. While the offshore wind map does not include data for Hawaii, the potential of approximately $100 \mathrm{TWh} / \mathrm{year}$ is included in the overall offshore wind technical potential.

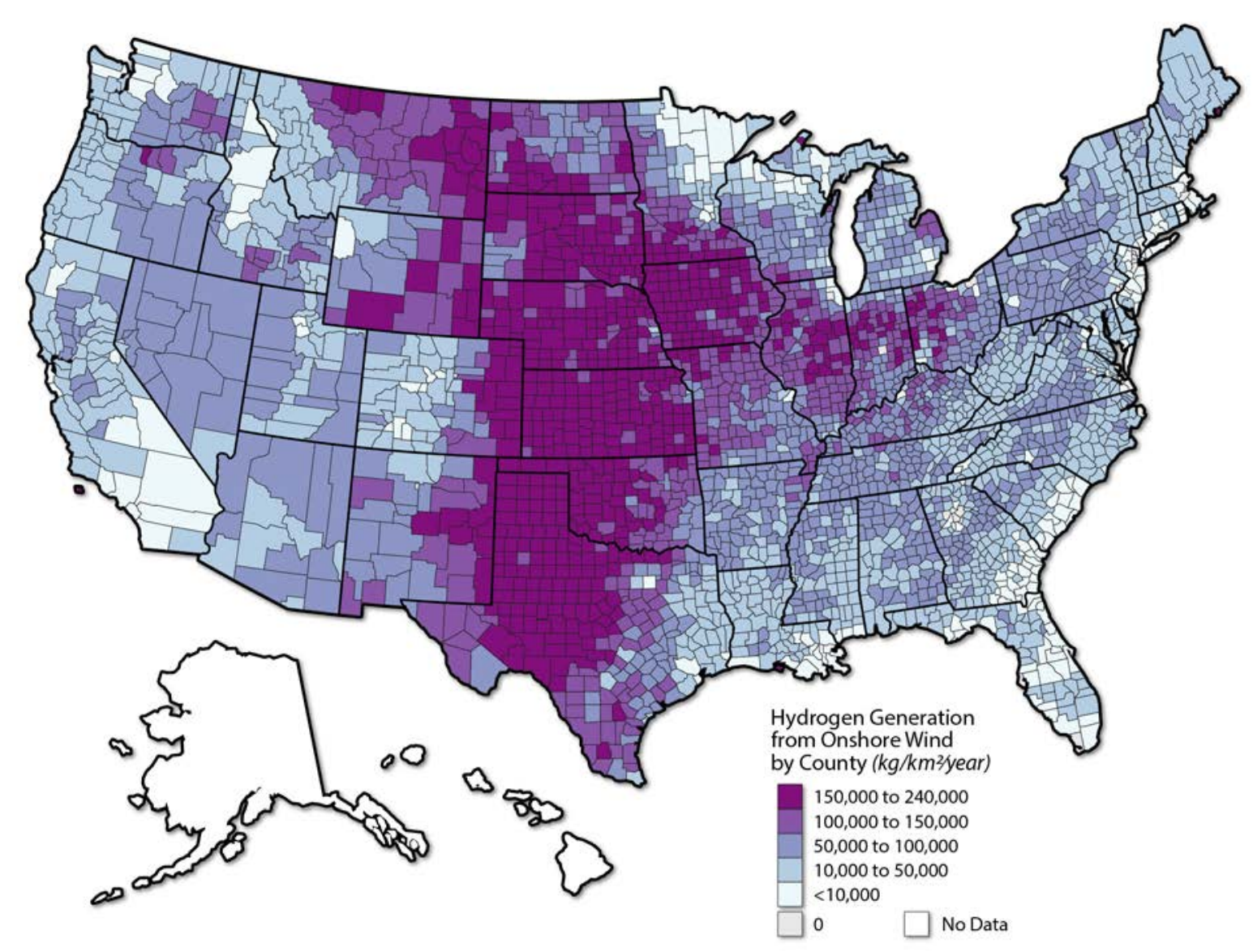

Figure 8. Hydrogen production potential from onshore wind resources, by county land area 


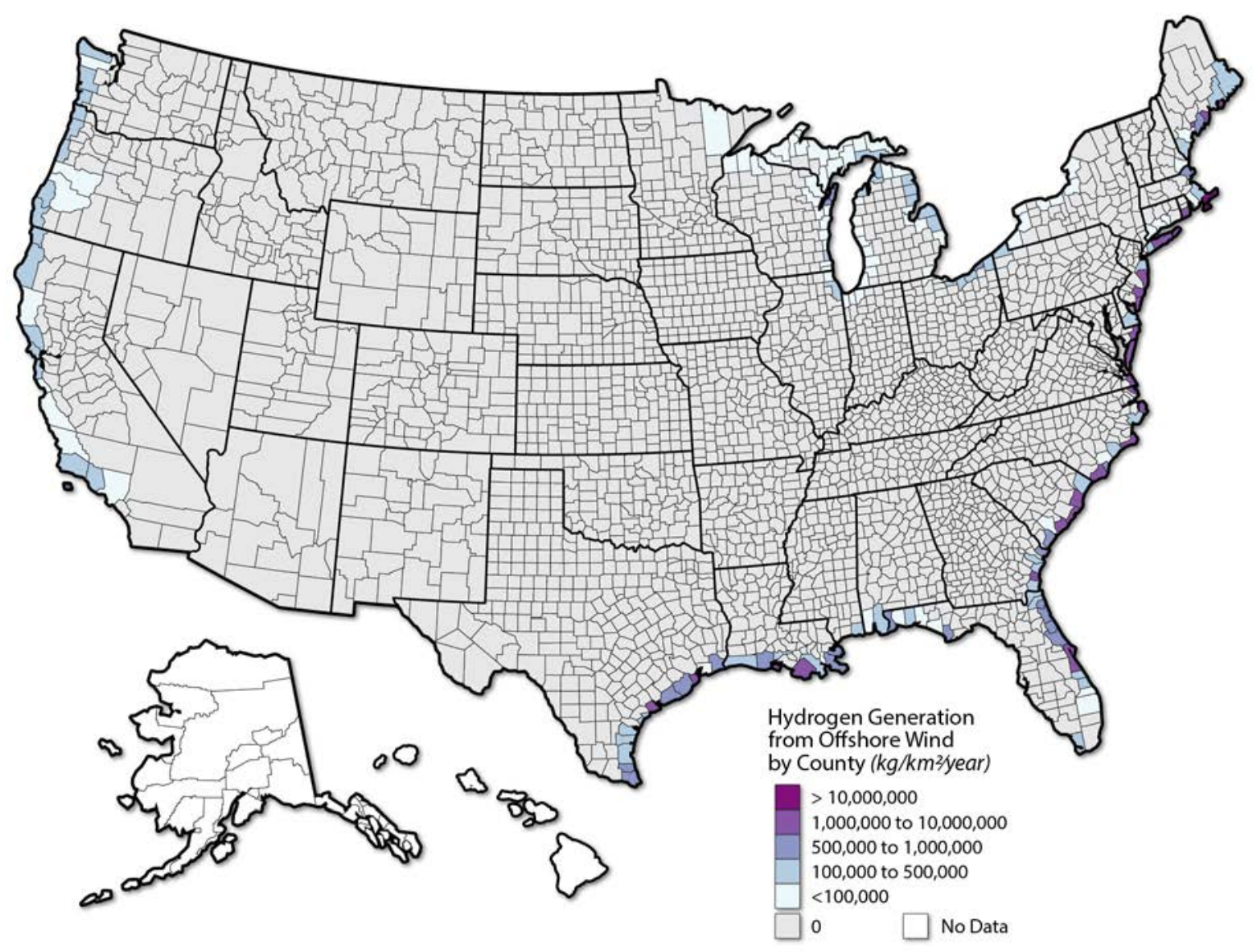

Figure 9. Hydrogen production potential from offshore wind resources, by county land area

\section{Solar Resources}

The technical potential for solar resources includes rooftop PV, utility-scale PV, and concentrating solar power (CSP). A 2016 NREL study (Gagnon et al. 2016) is used to update the rooftop PV technical potential. Gagnon et al. (2016) estimated a total annual generation potential of 1,432 TWh per year across small, medium, and large building classes. This technical potential estimate is approximately $75 \%$ higher than the estimate used in the 2013 Resource Report from Lopez et al. (2012). As mentioned in Gagnon et al. (2016), this increase can be attributed to: (i) increases in module power density, (ii) improved estimation of building suitability, (iii) higher estimates of the total number of buildings, and (iv) improvements in PV performance simulation tools that previously tended to underestimated production. The geographic distribution of hydrogen production potential from rooftop PV is shown by state, due to lack of higher resolution data, in Figure 10.

The technical generation potential of utility-scale PV systems is estimated at 184,200 TWh per year using the reV model (Maclaurin et al. 2019). This updated technical potential of utility-scale $\mathrm{PV}$ is approximately $35 \%$ lower than the estimate used in the 2013 Resource Report from Lopez et al. (2012). The most notable differences between the utility-scale PV potential from Lopez et al. (2012) and the updated potential estimate from the reV model are a decrease in the assumed power density (from 48 to $32 \mathrm{MW} / \mathrm{km}^{2}$ ) and the current exclusion of Alaska and Hawaii (which 
is expected to account for approximately $5 \%$ or $8,300 \mathrm{TWh}$ of the dfference). The geographic distribution of hydrogen production potential from utility-scale PV is indicated in Figure 11. Land exclusions can be found in Appendix C of Maclaurin et al. (2019), including land with a slope greater than $5 \%$, federal lands, and forests, among others.

The CSP technical potential is derived from Table 13 of Murphy et al. (2019), which calculates the available resource at $16,691 \mathrm{GW}$. To calculate the technical generation potential, the available resource is multiplied by the given capacity factor (which corresponds to a solar multiple of 1) and the solar multiple of 2.4 assumed in the System Advisor Model default case (see Murphy et al. 2019 for details). The result is 76,126 TWh per year, approximately $35 \%$ lower than the estimate used in the 2013 Resource Report from Lopez et al. (2012). The geographic distribution of hydrogen production potential from CSP is shown in Figure 12. Due to lack of empirical data on land exclusions for CSP, a modified set of exclusions from onshore wind were assumed (Murphy et al. 2019). CSP installations were assumed to only occur if at least $5 \mathrm{~km}^{2}$ of contiguous area are available and if the topography indicates a slope of $3 \%$ or less (Murphy et al. 2019).

The combined technical potential of solar resources is approximately 262,000 TWh per year of generation, with 70\% from utility-scale PV, 1\% from rooftop PV, and 29\% from CSP. This level of solar technical potential translates into 5,100 MMT of hydrogen technical production potential (see Table 10). This estimated technical potential is approximately $35 \%$ lower than that reported in the 2013 Resource Report. 


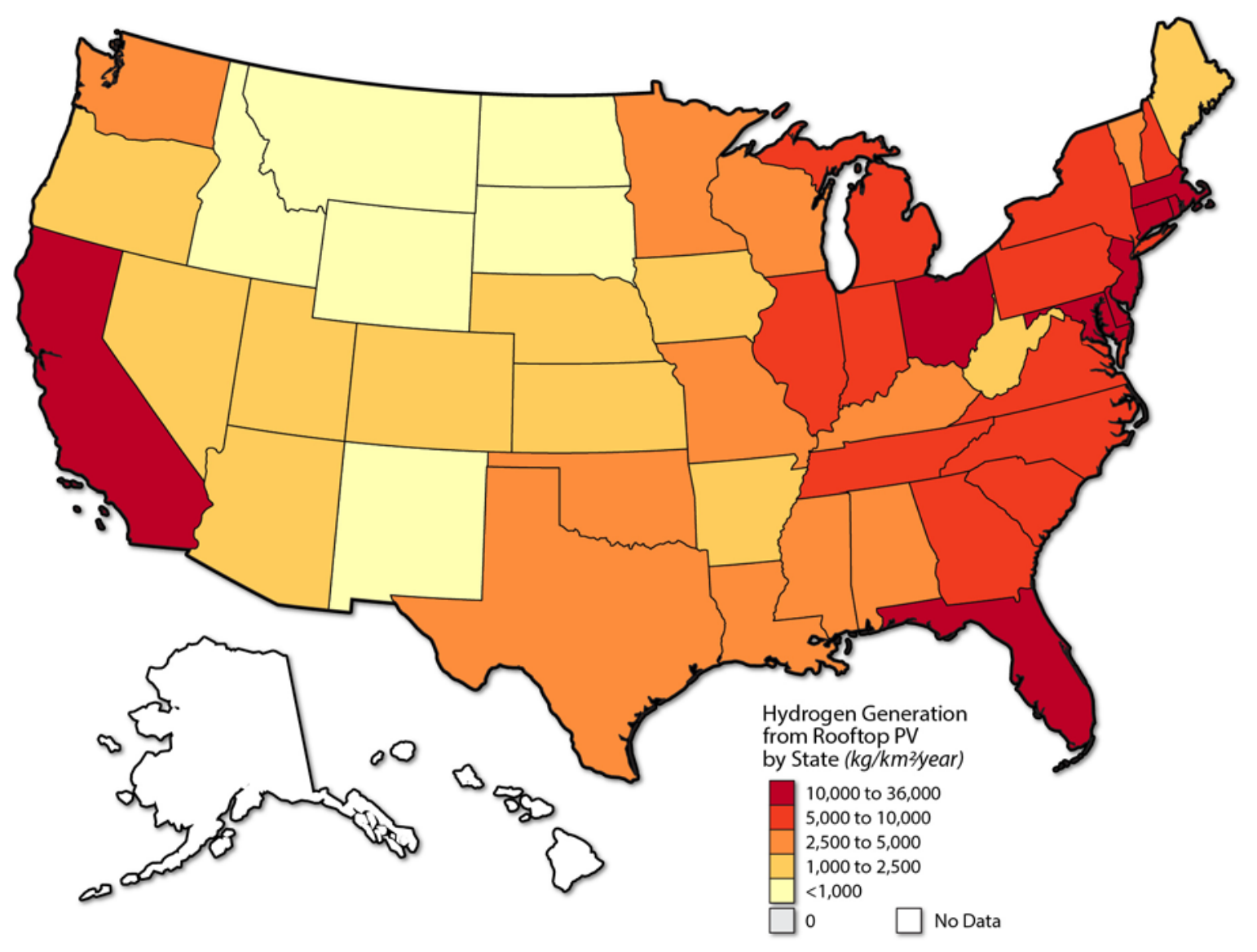

Figure 10. Hydrogen production potential from rooftop PV, by state land area 


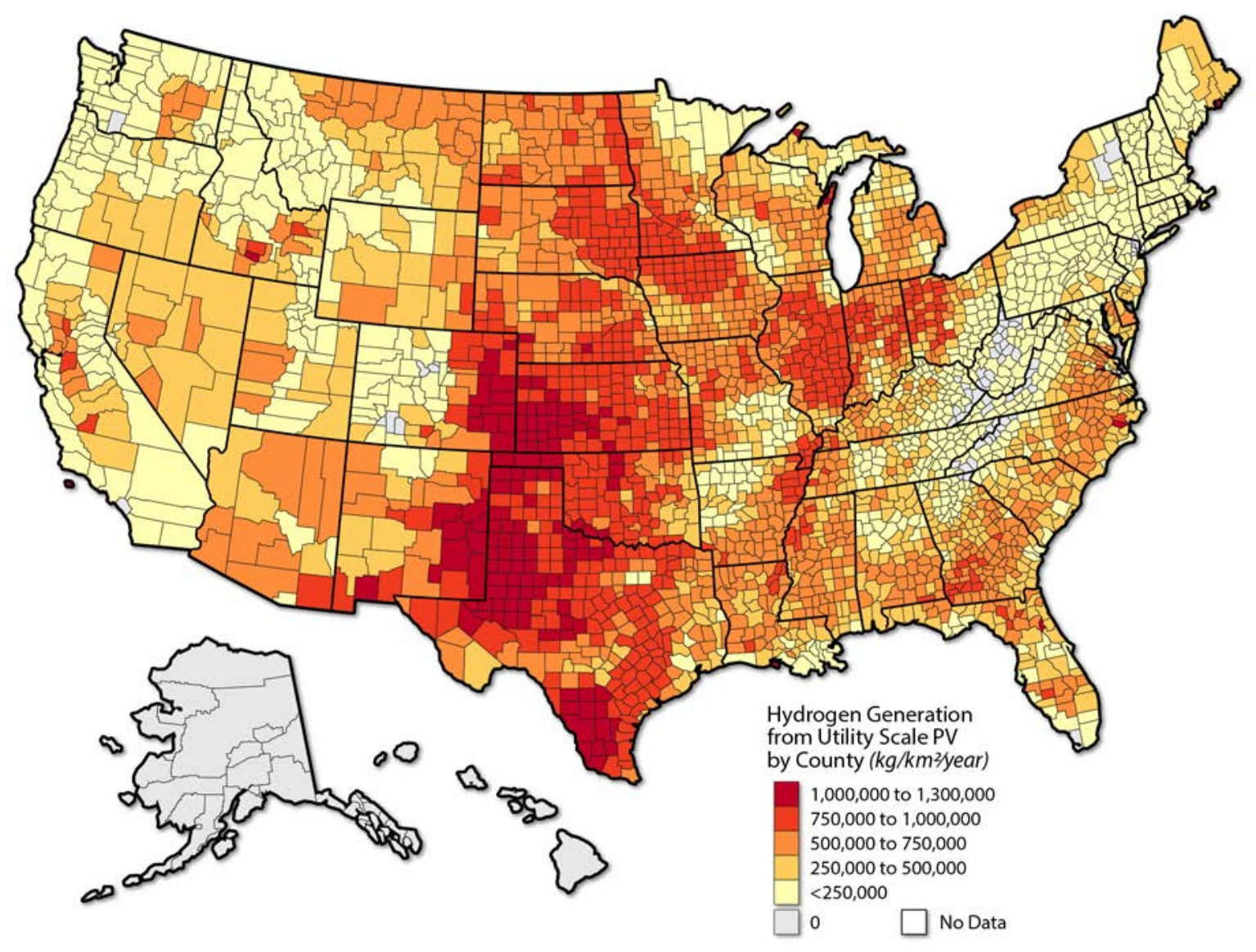

Figure 11. Hydrogen production potential from utility-scale PV, by county land area 


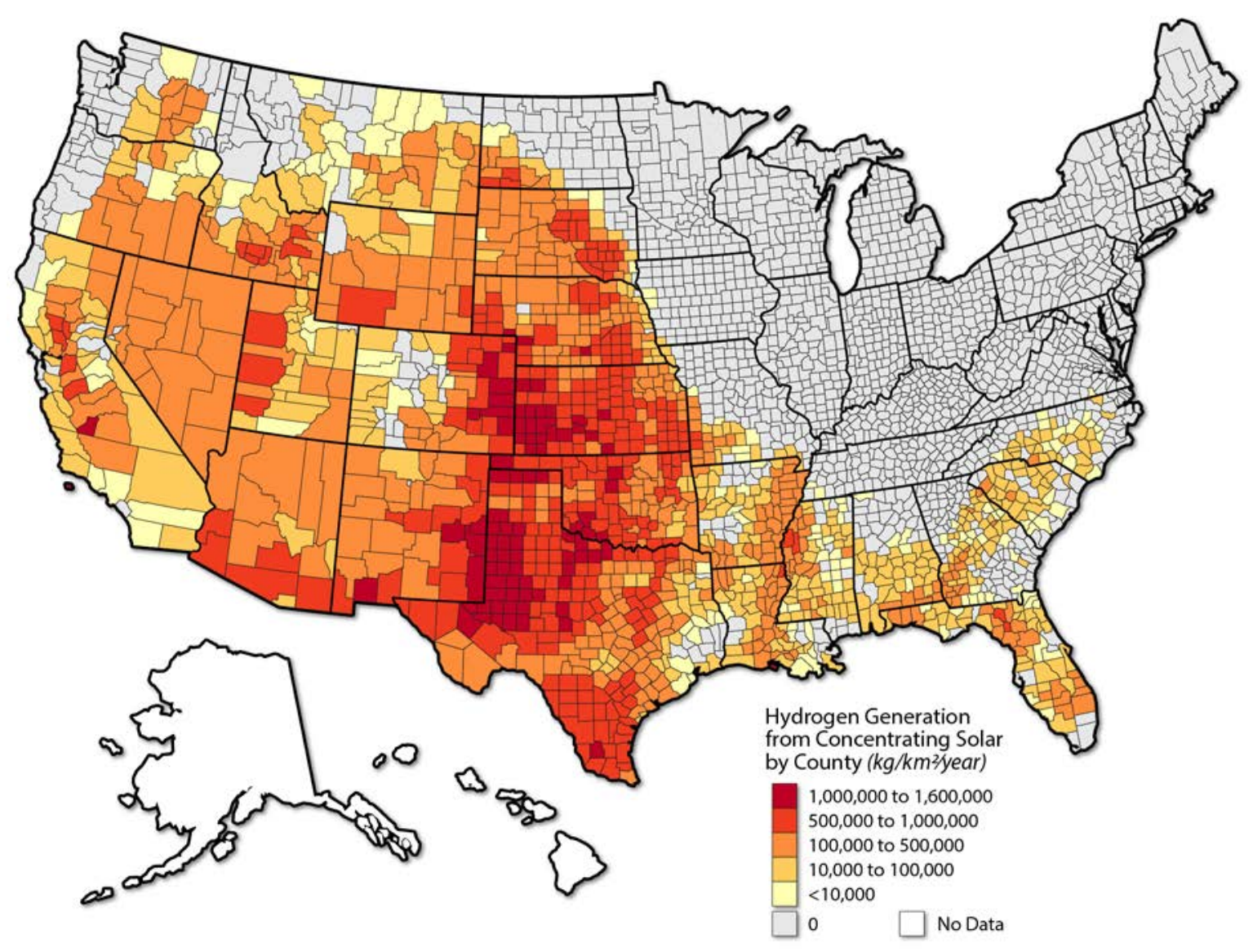

Figure 12. Hydrogen production potential from CSP, by county land area

\section{Water Power Resources}

In this study, high and low estimates are used to quantify the technical potential of water power resources in the United States. The low end of the technical potential includes current conventional hydropower assets and potential from non-powered dams and new stream-reach development. The high end of the technical potential adds to that the potential from marine and hydrokinetic technologies.

The existing hydropower assets (EHA) have been quantified by Oak Ridge National Laboratory (ORNL) as part of the HydroSource project (Johnson et al. 2019). The EHA potential includes $275 \mathrm{TWh} /$ year of conventional hydropower and $25 \mathrm{TWh} /$ year of pumped storage. In addition to the approximately 2,500 dams that constitute the EHA, the United States has more than 80,000 non-powered dams that could potentially produce hydroelectric power (Hadjerioua et al. 2012). A 2012 ORNL study (Hadjerioua et al. 2012) estimated the potential generation from adding power production capability to approximately 55,000 of the non-powered dams to be 45 TWh/year. ORNL has also estimated the technical resource capacity and generation for new stream-reach development. Excluding areas protected by federal legislation (e.g., national parks and wilderness areas), new stream-reach development could generate $347 \mathrm{TWh} /$ year (Kao et al. 2014). Thus, the low technical potential for hydropower resources is estimated to be almost 700 TWh/year. 
Marine and hydrokinetics (MHK) is an emerging industry with a number of technologies that could potentially convert the energy of waves, tides, and river and ocean currents into electricity. Because the technical potential from MHK is technology dependent, estimating the technically extractable resource is complex and uncertain. Table 2 describes the ranges of MHK technical energy potential by resource as given in the DOE Quadrennial Technology Review (DOE 2015, Chapter 4). The total technical potential of MHK resources ranges from 1,285 to 1,846 $\mathrm{TWh} /$ year, with only 538-757 TWh/year estimated for the continental United States.

\section{Table 2. Marine and Hydrokinetics Technical Energy Resource Estimates}

Source: DOE 2015, Table 4.N.2

\begin{tabular}{|l|l|l|}
\hline \multirow{2}{*}{ MHK Resource } & \multicolumn{2}{|l|}{ Technical Resource (TWh/yr) } \\
& Total U.S. & Continental U.S. \\
\hline Wave Energy & $898-1,229$ & $378-472$ \\
\hline Tidal Current Energy & $222-334$ & $15-22$ \\
\hline Ocean Current Energy & $45-163$ & $45-163$ \\
\hline River Current Energy & 120 & 100 \\
\hline \hline Total & $\mathbf{1 , 2 8 5 - 1 , 8 4 6}$ & $\mathbf{5 3 8 - 7 5 7}$ \\
\hline
\end{tabular}

The technical potential of water power resources, excluding MHK, translates to a hydrogen production potential of approximately 14 MMT/year. Figure 13, Figure 14, and Figure 15 show the hydrogen production potential from EHA by county, non-powered dam by hydrologic region, and new stream-reach development by state, respectively. Including MHK results in an estimated technical hydrogen production potential of about $50 \mathrm{MMT} / \mathrm{year}$. 


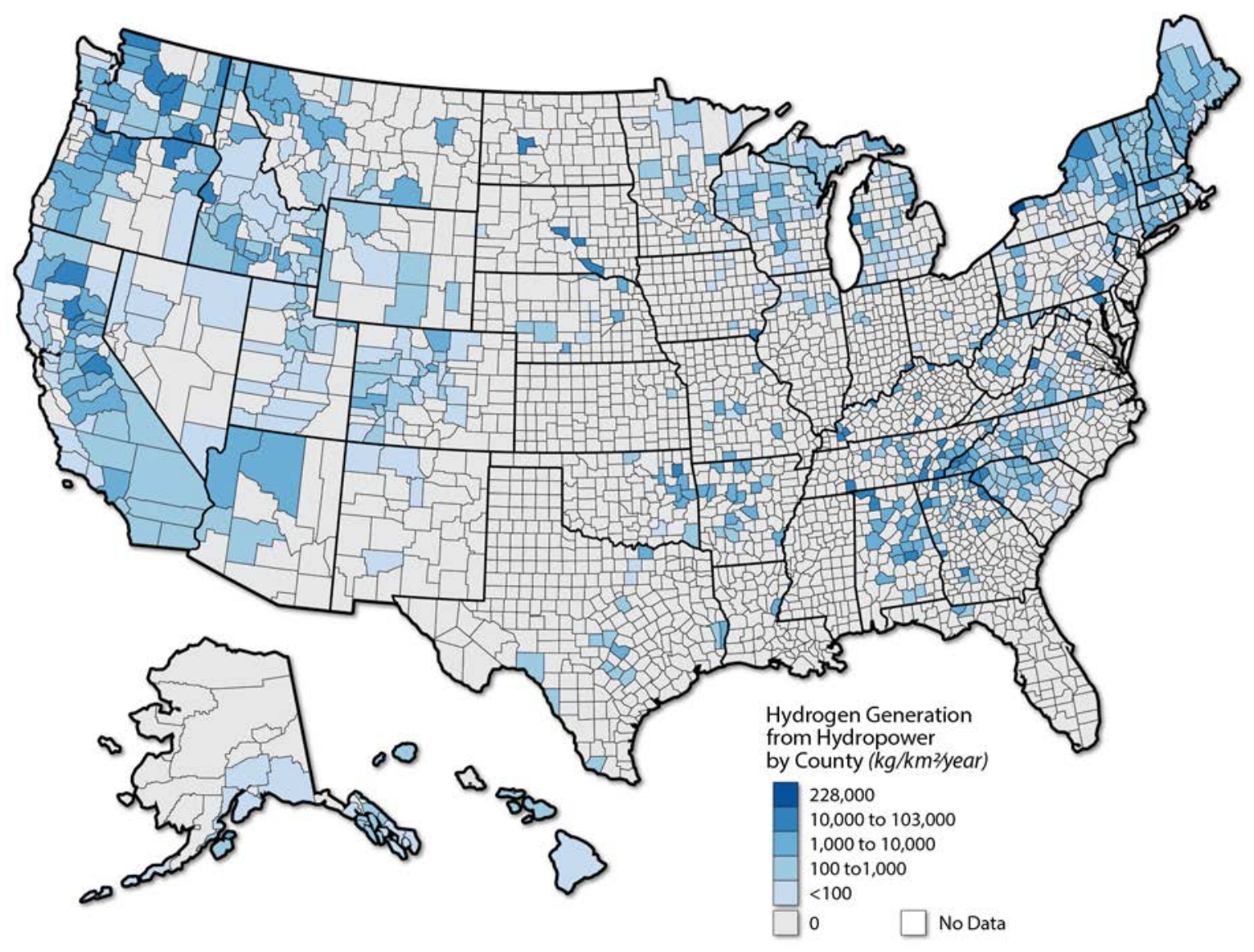

Figure 13. Hydrogen production potential from existing hydropower assets, by county land area 


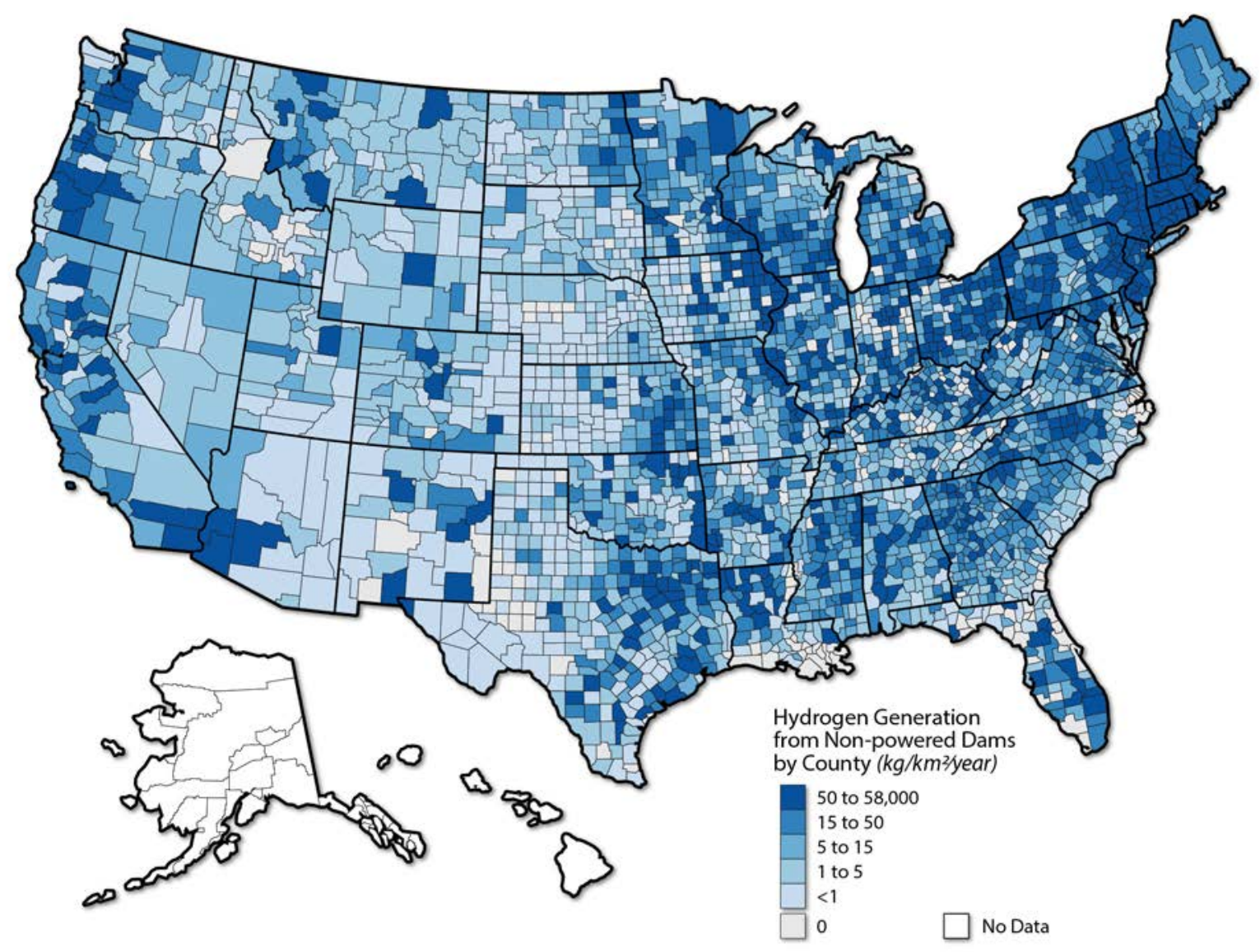

Figure 14. Hydrogen production potential from non-powered dams, by U.S. hydrologic region (HUC2) land area 


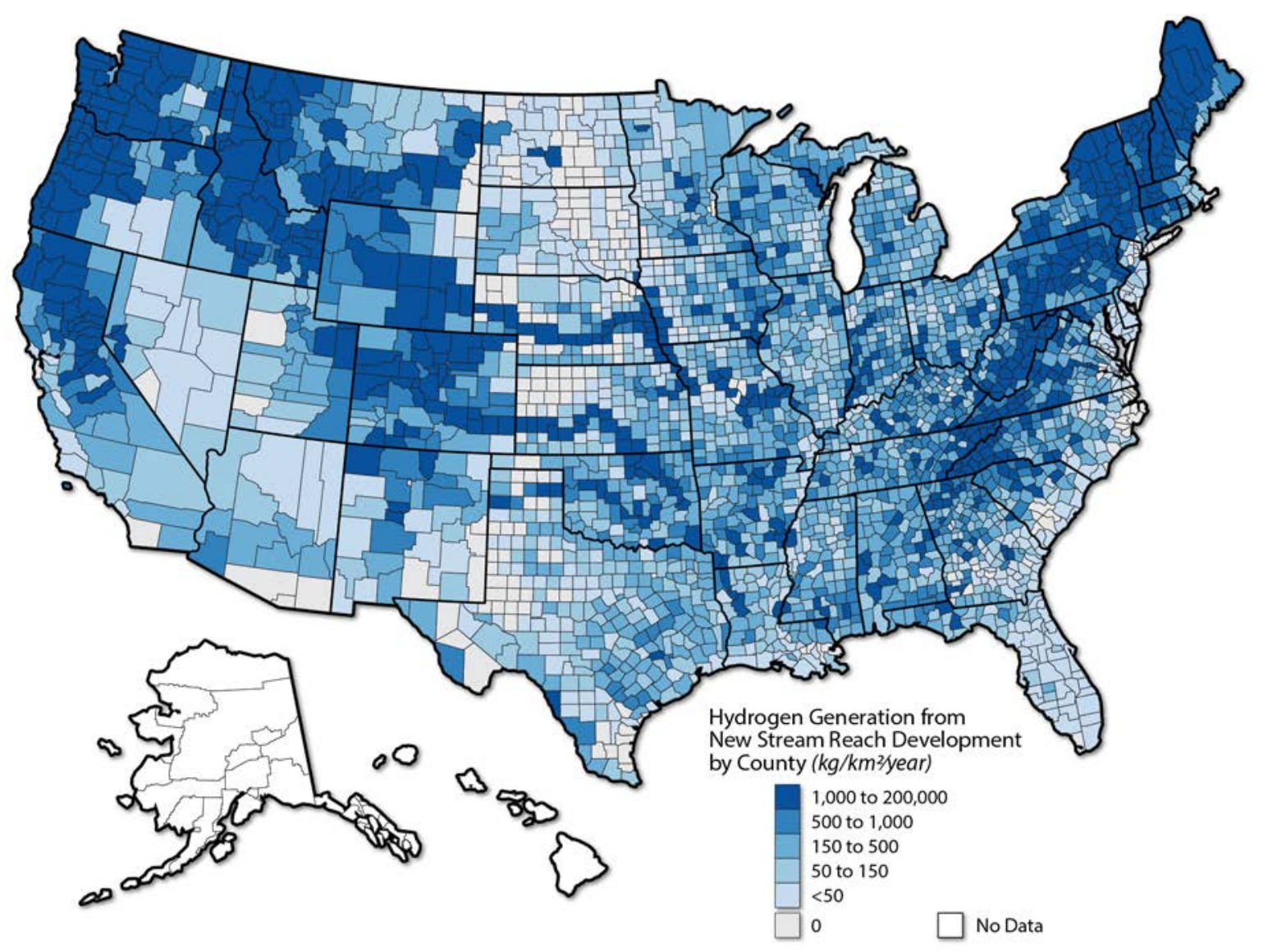

Figure 15. Hydrogen production potential from new stream-reach development, by state land area

\section{Geothermal Resources}

The United States produces the most geothermal electricity in the world, though geothermal energy currently accounts for only $0.4 \%$ of U.S. electricity generation (Augustine et al. 2019) or approximately $20 \mathrm{TWh} /$ year (EIA 2019, Table 17). The installed nameplate geothermal capacity is more than $3 \mathrm{GW}$ (Augustine et al. 2019), which can provide $2.5 \mathrm{GW}$ of net summer capacity to the grid (EIA 2019g).

The technical potential of geothermal resources is based on research for the DOE Geothermal Vision (GeoVision) study and is detailed in the GeoVision Analysis Supporting Task Force Report: Electric Sector Potential to Penetration (Augustine et al. 2019; DOE 2019). The geothermal resource availability estimated in the "Business-as-Usual" (BAU) scenario is shown in Table 3 and used to estimate the technical potential of geothermal power generation and hydrogen production potential. To convert this potential capacity to potential generation, a capacity factor of $90 \%$ is assumed for flash plants and $80 \%$ is assumed for binary plants (Augustine et al. 2019, Table 10), assuming the breakdown shown in Table 4 (NREL 2019). Similar to the water power resources, we estimate a low and high technical potential, based on the exclusion and inclusion of enhanced geothermal system potential, respectively. Thus, the low technical potential of geothermal power generation is estimated at approximately $190 \mathrm{TWh} / \mathrm{year}$ 
while the high potential is estimated at $26,800 \mathrm{TWh} /$ year. For comparison, the 2040 projected geothermal power production is estimated at $55 \mathrm{TWh} /$ year (EIA 2019, Table 17).

Enhanced geothermal systems (EGS) constitute $99 \%$ of the high technical potential of geothermal resources, with a generation potential of approximately 25,000 TWh/year. However, EGS technologies are at a relatively low technology readiness level and are not yet commercially available, and thus they are excluded from the low estimate of technical hydrogen production potential. The low and high hydrogen production potential is approximately $4 \mathrm{MMT} / \mathrm{year}$ and $480 \mathrm{MMT} /$ year, respectively. Figure 16 shows geographic resource distribution of geothermal potential applicable to binary and flash plant technologies.

Table 3. Summary of Geothermal Resource Availability

Source: Augustine et al. 2019, Table 4

\begin{tabular}{|l|l|l|l|}
\hline Geothermal Resources & $\begin{array}{l}\text { BAU Scenario } \\
\text { Availability (MWe) }\end{array}$ & $\begin{array}{l}\text { Estimated Power } \\
\text { Generation } \\
\text { Potential (TWh/yr) }\end{array}$ & $\begin{array}{l}\text { Estimated Hydrogen } \\
\text { Esoduction Potential } \\
\text { (MMT/yr) }\end{array}$ \\
\hline Identified Hydrothermal & 5,078 & 38 & 0.7 \\
\hline Undiscovered Hydrothermal & 18,830 & 143 & 2.8 \\
\hline $\begin{array}{l}\text { Near Field Enhanced } \\
\text { Geothermal System }\end{array}$ & 1,382 & 10 & 0.2 \\
\hline $\begin{array}{l}\text { Deep Enhanced } \\
\text { Geothermal System }\end{array}$ & $3,375,275$ & 24,628 & 480.1 \\
\hline \hline TOTAL & $\mathbf{3 , 4 0 0 , 5 6 5}$ & $\mathbf{2 4 , 8 1 9}$ & $\mathbf{4 8 3 . 8}$ \\
\hline
\end{tabular}

a Power generation potential is calculated assuming $90 \%$ capacity factor for flash plants and $80 \%$ for binary plants (Augustine et al. 2019, Table 10) according to the breakdown described in Table 4.

${ }^{b}$ Hydrogen production potential is calculated assuming conversion via low temperature electrolysis.

Table 4. Breakdown of Geothermal Resource by Plant Type

Source: NREL 2019

\begin{tabular}{|l|l|l|}
\hline \multicolumn{1}{|c|}{ Flash } & Binary \\
\hline Hydrothermal & $64.2 \%$ & $35.8 \%$ \\
\hline NF EGS & $56.9 \%$ & $43.1 \%$ \\
\hline Deep EGS & $32.9 \%$ & $67.1 \%$ \\
\hline
\end{tabular}




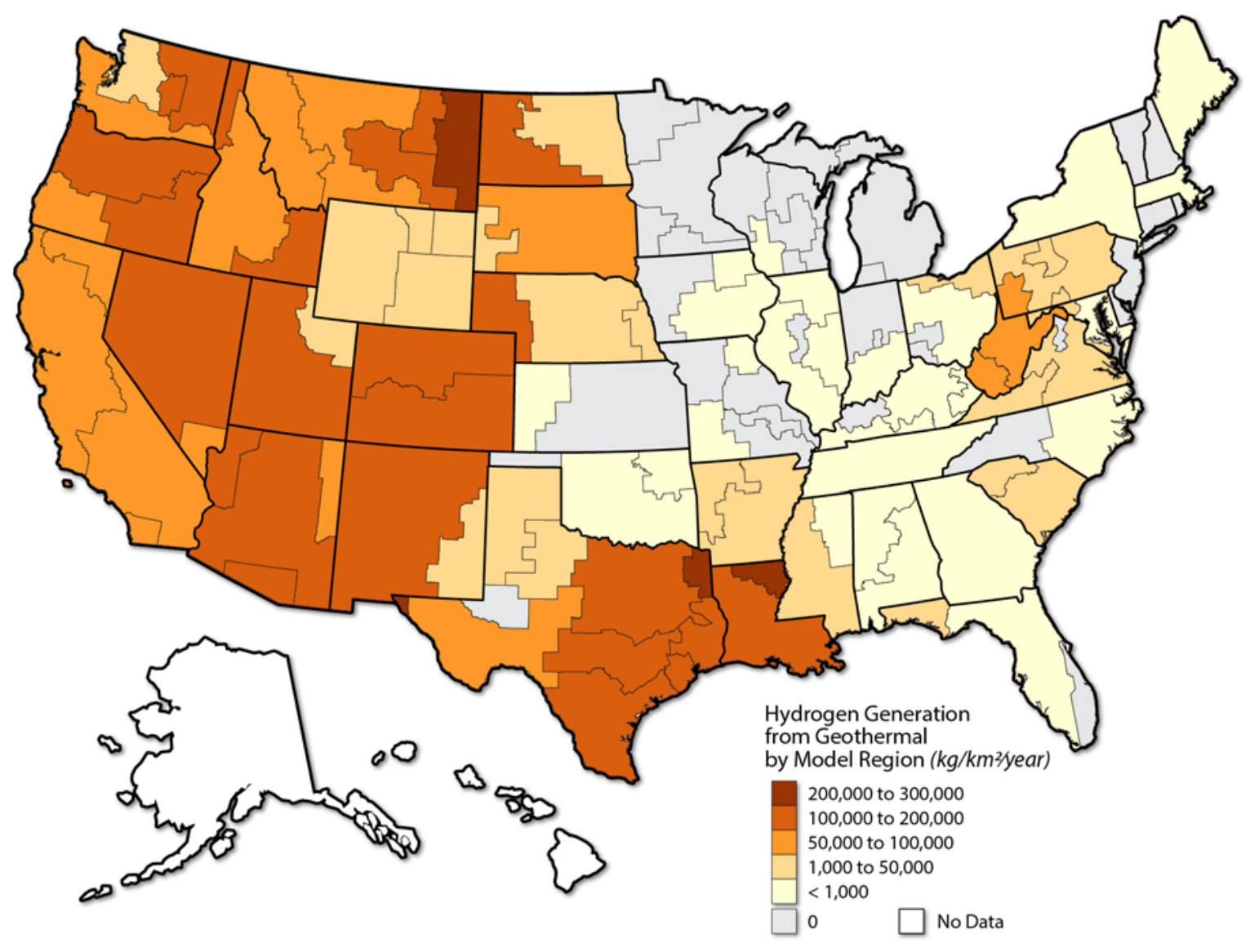

Figure 16. Hydrogen production potential from geothermal flash and binary plants by power control area land area 


\section{Combined Renewable Hydrogen Production Potential}

The total renewable hydrogen production potential from biomass, wind, solar, and hydropower is depicted in terms of total kilograms per year per county, normalized by county area, in Figure 17. Only the resources for which county-level data were available are included in the figure. Thus, this total only includes biomass resources, wind resources, utility-scale PV and CSP, and conventional hydropower.

Figure 18 shows which of these renewable resources offers the highest hydrogen generation potential, by county. Again, this map only includes the resources for which county-level data were available; considering the significant technical potential of MHK, it is expected that this resource could dominate some of the coastal counties. As it is represented here, however, solar and wind resources tend to dominate. Especially along the Appalachian Mountains, wind appears dominant likely because the slope of the land precludes solar technologies. Gaseous biomass and conventional hydropower appear dominant in Alaska and Hawaii; however, this is likely because data on other renewables were not available for these states. 


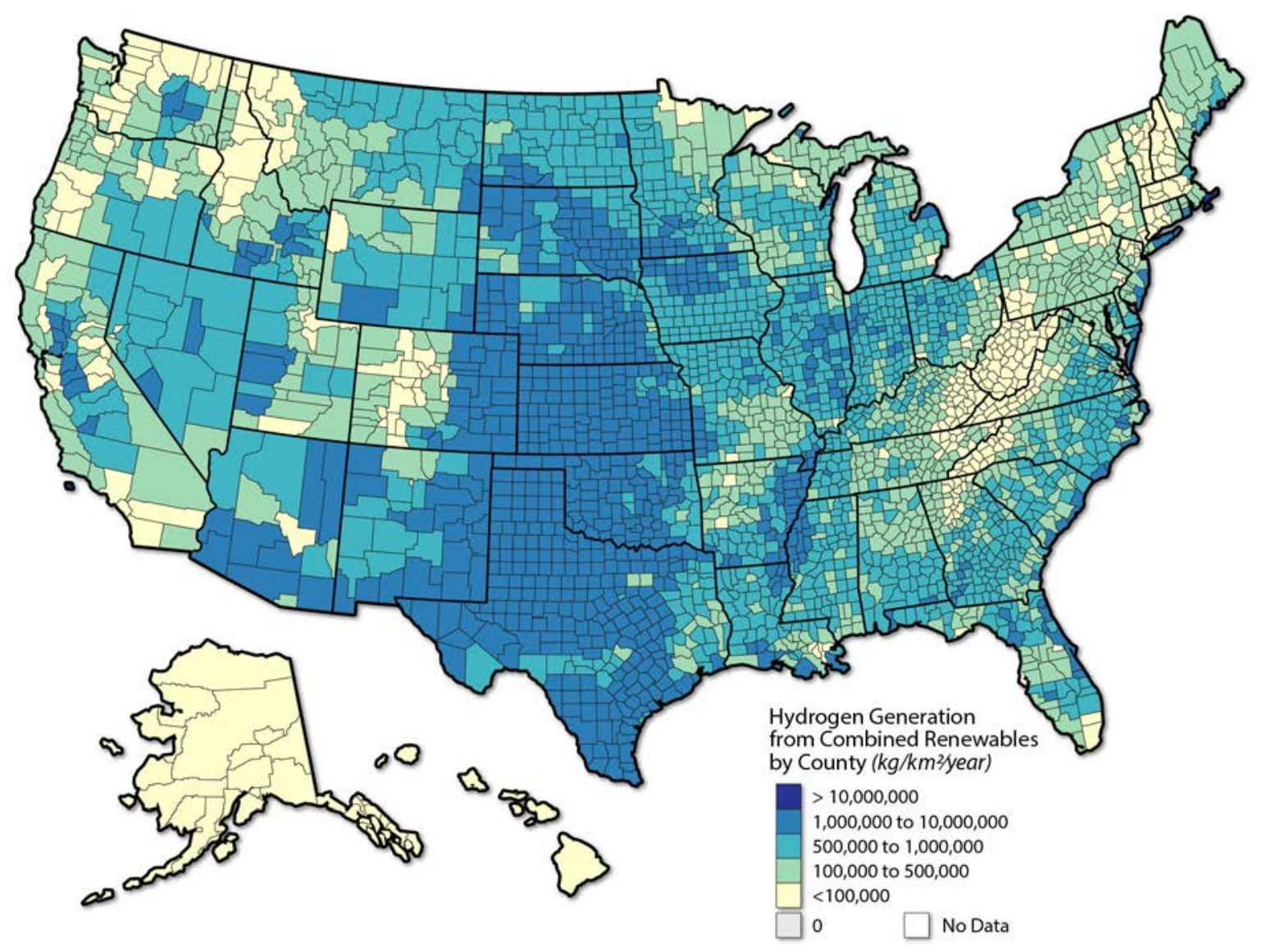

Figure 17. Hydrogen production potential from renewable resources, by county land area 


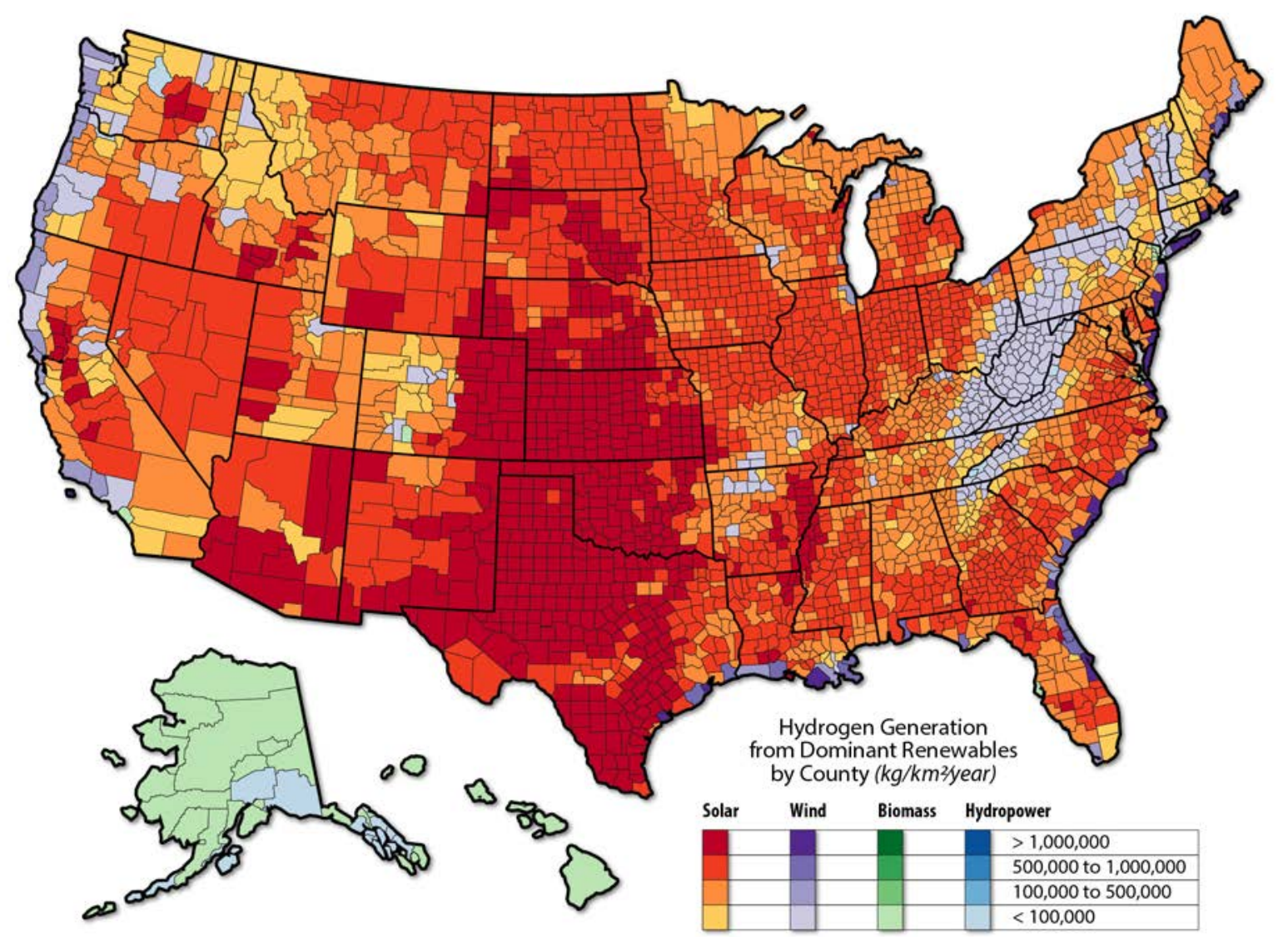

Figure 18. Hydrogen production potential from dominant renewable resources, by county land area 


\section{Hydrogen Production Potential Summary}

Table 5 summarizes energy inputs required to produce 1 kilogram of hydrogen from each resource. Conversion pathways and production efficiencies, on an LHV basis, are shown for each resource. The required coal value has been updated from the 2013 Resource Report to be consistent with the NETL (2010) state-of-the-art coal case (2.2 case study) production process energy efficiency. Key conversion factors are indicated in Table 6. We assume wind, solar, water power, and geothermal resources produce hydrogen at a rate of $51.3 \mathrm{kWh} / \mathrm{kg}$ hydrogen via central electrolysis (see H2A case study).

Hydrogen production potential estimates for the nuclear pathway include updated assumptions about uranium use that are not included in the most recent H2A case studies. For HTE, we assume a nominal burnup rate of $60 \mathrm{GWdt} /$ tonne $\mathrm{U}$, as well as an estimate that a $600 \mathrm{MWt}$ plant can produce $85 \times 10^{6} \mathrm{scf} /$ day of hydrogen, and therefore has a conversion efficiency of $50.2 \%$ for heat to hydrogen (LHV) (O'Brien 2017). These assumptions result in a nominal use rate of $4.62 \times 10^{-5} \mathrm{~kg} \mathrm{U} / \mathrm{kg}$ hydrogen. This value is used to determine uranium resource requirements for the HTE production pathway. Both the nominal burnup rate and the daily hydrogen production for a $600 \mathrm{MWt}$ plant have been updated since the 2013 Resource Report, resulting in a higher conversion efficiency and lower uranium-to-hydrogen use rates. The nuclear production efficiency described above is detailed further in Appendix A. 
Table 5. Amount of Renewable and Non-Renewable Resources Required to Produce $1 \mathrm{~kg}$ of Hydrogen and Production Efficiencies

\begin{tabular}{|c|c|c|c|c|}
\hline Resource & Conversion Pathway & \multicolumn{2}{|c|}{ Amount to Produce 1 kg Hydrogen ${ }^{a}$} & $\begin{array}{l}\text { Production Efficiency } \\
\left(E_{\text {out }} / E_{\text {in }}, \text { LHV) }\right.\end{array}$ \\
\hline Natural gas & Steam methane reforming & $167 \mathrm{scf}$ & $165 \mathrm{MJ}$ & $73.0 \%$ \\
\hline Coal (bituminous) & Coal gasification & $8.6 \mathrm{~kg}$ & $225 \mathrm{MJ}$ & $53.3 \%$ \\
\hline $\begin{array}{l}\text { Nuclear } \\
\text { (uranium) }\end{array}$ & High-temperature electrolysis & $4.62 \times 10^{-5} \mathrm{~kg} \mathrm{U}$ & $240 \mathrm{MJ}$ & $50.2 \%$ \\
\hline Biomass & Biomass gasification & $13.0 \mathrm{~kg}$ bone dry biomass & $242 \mathrm{MJ}$ & $48.3 \%$ \\
\hline Biomethane & Steam methane reforming & $3.29 \mathrm{~kg}$ methane & $165 \mathrm{MJ}$ & $73.0 \%$ \\
\hline $\begin{array}{l}\text { Wind power } \\
\text { Solar power } \\
\text { Water power } \\
\text { Geothermal }\end{array}$ & Low-temperature electrolysis & $51.3 \mathrm{kWh}$ & $185 \mathrm{MJ}$ & $64.9 \%$ \\
\hline
\end{tabular}

$\mathrm{MJ}=$ megajoule

a Values are derived from H2A future central case studies for each resource type and from the central PEM electrolysis case study for wind, solar, geothermal, and water power. The $167 \mathrm{scf}$ per $\mathrm{kg}$ for steam methane reforming is derived from the future central steam methane reforming case study, assuming the GREET LHV/HHV ratio of 0.903 and EIA HHV of 1,036 Btu/scf. The coal requirement is based on NETL (2010) case 2.2 and the GREET (2018) LHV of bituminous coal of 22.6 million Btu/ton. Uranium consumption for the nuclear HTE production pathway is described above. The $13.0 \mathrm{~kg}$ bone dry biomass is from the future central biomass gasification case study. Biomethane is assumed to have an LHV of $50 \mathrm{MJ} / \mathrm{kg}$ (Saur and Milbrandt 2014). The H2A case studies are available from the DOE H2A website: http://www.hydrogen.energy.gov/h2a prod studies.html.

${ }^{b}$ Production efficiency is defined as the energy of the hydrogen out of the production process (on an LHV basis) divided by the sum of the energy into the process from the feedstock. The production efficiencies in this table do not account for any additional input feedstock consumption or electricity byproduct credits.

Efficiency definitions are distinct in that resource "energy in" is in different forms, as noted in the column indicating MJ of resource required. Production efficiencies indicated for low-temperature electrolysis are based on system electrical energy input ( $51.3 \mathrm{kWh}$, including electricity requirements for balance of plant) and nuclear efficiency is on a heat input basis. 
Table 6. Conversion Assumptions

\begin{tabular}{|c|c|c|c|}
\hline Metric & Value & Units & Source \\
\hline \multicolumn{4}{|l|}{ Coal (Bituminous) } \\
\hline Required coal & 8.6 & $\mathrm{~kg} \mathrm{coal} / \mathrm{kg}$ hydrogen & NETL (2010) Case 2.2 \\
\hline Coal energy content & 22.6 & million Btu/ton (HHV) & GREET (2018) \\
\hline \multicolumn{4}{|l|}{ Natural Gas } \\
\hline Required natural gas & 156,000 & $\begin{array}{l}\text { Btu natural gas } / \mathrm{kg} \\
\text { hydrogen }\end{array}$ & H2A Future Case Study \\
\hline Gas Btu content & 1,036 & Btu per scf $(\mathrm{HHV})$ & $\begin{array}{l}\text { March } 2020 \text { Monthly } \\
\text { Energy Review (EIA } \\
\text { 2020b) }\end{array}$ \\
\hline \multicolumn{4}{|l|}{ Solid Biomass } \\
\hline Required biomass & 13.0 & $\begin{array}{l}\mathrm{kg} \text { biomass } / \mathrm{kg} \\
\text { hydrogen }\end{array}$ & H2A Future Case Study \\
\hline \multirow[t]{2}{*}{ Biomass energy content } & 18.6 & MJ/kg biomass (LHV) & $\begin{array}{l}\text { H2A Conversion Factor } \\
\text { (Biomass Multi-Year } \\
\text { Program Plan Feedstock) }\end{array}$ \\
\hline & 19.7 & $\mathrm{MJ} / \mathrm{kg}$ biomass $(\mathrm{HHV})$ & Lopez et al. (2012) \\
\hline \multicolumn{4}{|l|}{ Biomethane } \\
\hline Required biomethane & 3.29 & $\begin{array}{l}\mathrm{kg} \text { biomethane } / \mathrm{kg} \\
\text { hydrogen }\end{array}$ & $\begin{array}{l}\text { Saur and Milbrandt } \\
\text { (2014) }\end{array}$ \\
\hline \multirow{2}{*}{ Biomethane energy content } & 50.0 & $\begin{array}{l}\text { MJ/kg biomethane } \\
(\mathrm{LHV})\end{array}$ & $\begin{array}{l}\text { Saur and Milbrandt } \\
\text { (2014) }\end{array}$ \\
\hline & 56.4 & $\begin{array}{l}\text { MJ/kg biomethane } \\
(\mathrm{HHV})\end{array}$ & Lopez et al. (2012) \\
\hline \multicolumn{4}{|c|}{ Wind, Solar, Water, and Geothermal Power } \\
\hline $\begin{array}{l}\text { System electricity } \\
\text { requirement }\end{array}$ & 51.3 & kWh/kg hydrogen & H2A Future Case Study \\
\hline \multicolumn{4}{|l|}{ Nuclear Power } \\
\hline HTE & $50.2 \%$ & Thermal conversion & O'Brien (2017) \\
\hline Uranium use & $4.62 * 10^{-5}$ & $\begin{array}{l}\mathrm{kg} \text { uranium per } \mathrm{kg} \\
\text { hydrogen }\end{array}$ & O'Brien (2017) \\
\hline
\end{tabular}

Note: heating values or conversions unique to a particular publication were used for some calculations. 


\section{Hydrogen Production Requirements}

This report considers resource requirements to meet only one quantity of hydrogen demand in 2040, $10 \mathrm{MMT}$ /year, which can be easily scaled to assess different scenarios. Current U.S. hydrogen production is approximately $10 \mathrm{MMT} /$ year (Connelly et al. 2019), so this future demand quantity would represent a doubling of current demand. This additional 10 MMT of hydrogen per year could correspond to the fuel demand of 50 million light-duty FCEVs, as described in the 2013 Resource Report, or for some mix of other end uses such as chemicals production, refining, energy storage, etc.

We estimate how much of any one of the energy resources analyzed in this report is required to provide $10 \mathrm{MMT}$ of hydrogen per year. By focusing on the single resource requirements, as opposed to a mix of resources, for this demand scenario, we provide a context for considering implications of possible future hydrogen demand with respect to specific resource constraints.

Table 7 shows fossil and nuclear resource availability, current consumption (2017), projected consumption (2040) under the AEO2019 Reference and Low Oil and Gas Resource and Technology scenarios, and the amount of resource needed to produce $10 \mathrm{MMT}$ of hydrogen. Table 8 shows the same metrics for the renewable energy resources on an annual basis. Both tables also describe the technical availability of energy resources. Values are indicated for both the AEO2019 Reference Case and the Low Oil and Gas Resource and Technology scenarios (EIA 2019a), where the latter involves higher costs and lower resource availability for oil and gas than in the Reference Case. The final two rows of each table describe the percent increase in projected 2040 resource consumption in order to produce $10 \mathrm{MMT} /$ year of hydrogen for both the Reference Case and Low Oil and Gas Resource and Technology scenarios, calculated using the following equation:

\section{Percent increase in consumption}

$$
=\left(\frac{\text { Projected consumption }+ \text { Requirement for } 10 M M T \mathrm{H}_{2}}{\text { Projected consumption }}-1\right) \times 100
$$


Table 7. Availability, Current Consumption, and Projected Consumption for Fossil and Nuclear Resources

\begin{tabular}{|c|c|c|c|}
\hline \multirow{2}{*}{ Resource Metric } & \multicolumn{3}{|c|}{ Fossil and Nuclear Pathways ${ }^{a}$} \\
\hline & Natural Gas ${ }^{\mathbf{b}}$ & Coalc $^{c}$ & Nuclear $^{d}$ (HTE) \\
\hline \multicolumn{4}{|l|}{ Resource Availability } \\
\hline Technical Resource Potential & 2,829 Tcf & $473 \mathrm{~B}$ tons & $353 \mathrm{M} \mathrm{Ib} \mathrm{U}_{3} \mathrm{O}_{8}$ \\
\hline \multicolumn{4}{|c|}{ Resource Consumption (without an additional $10 \mathrm{MMT}$ of hydrogen production) ${ }^{\mathrm{e}}$} \\
\hline Current (2017) & $27.1 \mathrm{Tcf}$ & $642 \mathrm{M}$ tons & $885 \mathrm{TWh}$ \\
\hline Reference Case: 2040 & 33.3 Tcf & $487 \mathrm{M}$ tons & $728 \mathrm{TWh}$ \\
\hline $\begin{array}{l}\text { Low Oil and Gas Resource and Technology } \\
\text { Case: } 2040\end{array}$ & $26.5 \mathrm{Tcf}$ & $582 \mathrm{M}$ tons & $798 \mathrm{TWh}$ \\
\hline \multicolumn{4}{|l|}{ Required Resource for Hydrogen Production } \\
\hline 10 MMT of Hydrogen & $1.7 \mathrm{Tcf}$ & $78 \mathrm{M}$ tons & $256 \mathrm{TWh}$ \\
\hline Percent of Technical Potential & $0.06 \%$ & $0.02 \%$ & $0.4 \%$ \\
\hline \multicolumn{4}{|c|}{ Percent Increase in 2040 Resource Consumption to Produce 10 MMT of Hydrogen } \\
\hline Reference Case & $5 \%$ & $20 \%$ & $39 \%$ \\
\hline $\begin{array}{l}\text { Low Oil and Gas Resource and Technology } \\
\text { Case }\end{array}$ & $6 \%$ & $17 \%$ & $35 \%$ \\
\hline
\end{tabular}

Tcf $=$ trillion cubic feet; $\mathrm{B}=$ billion; $\mathrm{M}=$ million

a Calculations were made to determine the hydrogen quantity required. Some systems require input energy such as electricity or produce useful byproducts such as heat or electricity.

${ }^{b}$ Natural gas technical potential is based on Total Technically Recoverable Resources estimates at the beginning of 2018 (Assumptions to the Annual Energy Outlook 2020, Table 2 [EIA 2020a]).

${ }^{c}$ Coal technical potential is from the Demonstrated Reserve Base from the 2018 Annual Coal Report (EIA 2019b). Consumption, provided in quads by EIA, was converted to million tons using 19.44 million Btu/ton for 2017 consumption and 19.82 million Btu/ton for 2040 consumption (EIA 2020c).

${ }^{d}$ The nuclear production pathway for HTE is described above. Uranium resource technical potential is from 2018 uranium reserves at a forward-cost category of up to but less than $\$ 100 / 1 \mathrm{lb} \mathrm{U}_{3} \mathrm{O}_{8}(2018$ Domestic Uranium Production Report, Table 10 [EIA 2019c]).

e Current (2017) and projected (2040) resource consumption values are from the Reference Case and Low Oil and Gas Resource and Technology scenario from the 2019 Annual Energy Outlook (EIA 2019a). 
Table 8. Availability, Current Consumption, and Projected Consumption for Renewable Resources

\begin{tabular}{|c|c|c|c|c|c|}
\hline \multirow{2}{*}{ Resource Metric } & \multicolumn{5}{|c|}{ Renewable Pathways } \\
\hline & Biomass & Wind & Solar & $\begin{array}{l}\text { Water } \\
\text { Power }\end{array}$ & Geothermal \\
\hline \multicolumn{6}{|l|}{ Resource Availability ${ }^{a}$} \\
\hline $\begin{array}{l}\text { Annual Technical Resource } \\
\text { Potential }\end{array}$ & $\begin{array}{l}800 \mathrm{M} \\
\text { tons }\end{array}$ & $\begin{array}{l}38,000 \\
\text { TWh }\end{array}$ & $\begin{array}{l}260,000 \\
\text { TWh }\end{array}$ & $2,500 \mathrm{TWh}$ & 25,000 TWh \\
\hline \multicolumn{6}{|c|}{ Resource Consumption (without an additional 10 MMT of hydrogen production) ${ }^{b}$} \\
\hline Current (2017) & $\begin{array}{l}292 \mathrm{M} \\
\text { tons }\end{array}$ & $254 \mathrm{TWh}$ & 87 TWh & $298 \mathrm{TWh}$ & 16 TWh \\
\hline Reference Case: 2040 & $\begin{array}{l}329 \mathrm{M} \\
\text { tons }\end{array}$ & $382 \mathrm{TWh}$ & $547 \mathrm{TWh}$ & $307 \mathrm{TWh}$ & $56 \mathrm{TWh}$ \\
\hline $\begin{array}{l}\text { Low Oil and Gas Resource } \\
\text { and Technology Case: } 2040\end{array}$ & $\begin{array}{l}337 \mathrm{M} \\
\text { tons }\end{array}$ & $564 \mathrm{TWh}$ & $885 \mathrm{TWh}$ & $310 \mathrm{TWh}$ & $58 \mathrm{TWh}$ \\
\hline \multicolumn{6}{|c|}{ Required Resource for Hydrogen Production } \\
\hline 10 MMT of Hydrogen & $\begin{array}{l}143 \mathrm{M} \\
\text { tons }\end{array}$ & $513 \mathrm{TWh}$ & 513 TWh & $513 \mathrm{TWh}$ & 513 TWh \\
\hline $\begin{array}{l}\text { Percent of Annual Technical } \\
\text { Potential }\end{array}$ & $17.5 \%$ & $1.4 \%$ & $0.2 \%$ & $20.5 \%$ & $2.1 \%$ \\
\hline \multicolumn{6}{|c|}{ Percent Increase in 2040 Resource Consumption to Produce 10 MMT of Hydrogen } \\
\hline Reference Case & $44 \%$ & $134 \%$ & $94 \%$ & $167 \%$ & $916 \%$ \\
\hline $\begin{array}{l}\text { Low Oil and Gas Resource } \\
\text { and Technology Case }\end{array}$ & $42 \%$ & $91 \%$ & $58 \%$ & $165 \%$ & $884 \%$ \\
\hline
\end{tabular}

${ }^{a}$ The high estimates for water power (including MHK) and geothermal (including EGS) are shown as the annual technical resource potential.

${ }^{\mathrm{b}}$ Resource consumption values are from the Reference Case and Low Oil and Gas Resource and Technology scenario from the Annual Energy Outlook 2019 (EIA 2019, Renewable Energy Consumption by Sector and Source, table 17). Conversion to TWh is based on EIA average fossil fuel heat rates for electricity generation (EIA 2019f).

Biomass consumption converted from quads to million short tons assuming 8,500 Btu/lb (HHV) (Lopez et al. 2012).

The additional resource consumption for producing $10 \mathrm{MMT}$ of hydrogen per year is indicated graphically in Figure 19a for the BAU AEO2019 Reference Case scenario (EIA 2019a). To allow for comparison, all resource values have been converted to quads of fossil fuel equivalents from the values in Table 7 and Table 8 . The white bars indicate current consumption in 2017, and the blue crosshatched bars represent projected consumption in 2040 under Reference Case assumptions. The AEO2019 consumption levels for 2017 and 2040 represent consumption across all energy sectors, including buildings, electricity, industry, and transportation.

The stacked solid blue bars indicate the additional resource consumption to produce an additional 10 MMT of hydrogen in 2040. The percent increase in resource consumption to meet additional hydrogen demand varies by resource. The percent increases in projected resource consumption to meet $10 \mathrm{MMT}$ of hydrogen demand are indicated in parentheses along the horizontal axis for each resource. With respect to 2040 projected consumption in the Reference 
Case, these increases are approximately 5\% for natural gas, $20 \%$ for coal, $40 \%$ for nuclear, $45 \%$ for biomass, $135 \%$ for wind, $90 \%$ for solar, $165 \%$ for hydropower, and $915 \%$ for geothermal. ${ }^{15}$

The percent increases for wind and solar are significantly lower than the 2013 Resource Report estimated for wind (183\%) and solar (780\%) due to higher projected 2040 consumption of these resources in the AEO2019 Reference Case. These updated results indicate that $10 \mathrm{MMT} / \mathrm{year}$ of hydrogen demand no longer appears to exceed expected demand for solar, though it would still exceed expected demand for wind. The results confirm the conclusion from the 2013 Resource Report: $10 \mathrm{MMT} / \mathrm{year}$ of hydrogen demand would not place excessive strain on natural gas resources.

The AEO2019 Low Oil and Gas Resource and Technology scenario is used in this report to represent a future in which prices for oil and natural gas have increased, resulting in higher penetration of other energy resources such as wind and solar. We include projections from the AEO2019 Low Oil and Gas Resource and Technology scenario in Table 7 and Table 8 and in Figure 19b. The projected 2040 consumption of natural gas in the Low Oil and Gas Resource and Technology scenario is about $20 \%$ lower than that in the Reference Case, though the relative increase in consumption to produce $10 \mathrm{MMT}$ of hydrogen only increases from $5 \%$ to $6 \%$. The projected consumption of coal increases in the Low Oil and Gas Resource and Technology scenario, such that the percent increase to produce 10 MMT of hydrogen in 2040 decreases from $21 \%$ to $17 \%$. There are only modest increases in projected biomass, hydropower, and geothermal consumption in the Low Oil and Gas Resource and Technology scenario and thus only slight decreases in the relative consumption for hydrogen production to approximately $40 \%, 165 \%$, and $885 \%$, respectively. There is an approximately $90 \%$ and $60 \%$ increase in projected 2040 wind and solar consumption, respectively, in the Low Oil and Gas Resource and Technology scenario (compared to the Reference Case). The wind, solar, hydropower, and geothermal values, shown in quads, have been converted using EIA 2040 fossil fuel heat rates for electricity net generation of 8,017 Btu/kWh (Reference) and 8,858 Btu/kWh (Low Oil and Gas) (EIA 2019f), which result in different requirements to produce $10 \mathrm{MMT}$ of hydrogen between the two scenarios. ${ }^{16}$

This report focuses mainly on the individual resource potential to produce hydrogen and compares the potential and impact of hydrogen production across resources. While dedicated electrolyzers can be used to produce hydrogen from nuclear and renewable electricity sources, grid-integrated electrolyzers could also be used to meet future hydrogen demand. Figure 20 describes how grid-integrated electrolysis to produce $10 \mathrm{MMT}$ of hydrogen would increase electricity generation in 2040. The AEO projects 2040 electricity generation to be approximately $5,000 \mathrm{BkWh}$. Thus, the $513 \mathrm{BkWh}$ required to produce $10 \mathrm{MMT}$ of hydrogen via lowtemperature electrolysis (LTE) would constitute an approximately $10 \%$ increase in electricity generation.

\footnotetext{
${ }^{15}$ The GeoVision analysis projects higher geothermal energy consumption in 2040 than the EIA does, which if realized would result in closer to a $250 \%$ increase to produce $10 \mathrm{MMT}$ of hydrogen.

16 The electricity requirements remain the same (513 TWh as shown in Table 7); only the representation in quads varies between AEO scenarios.
} 


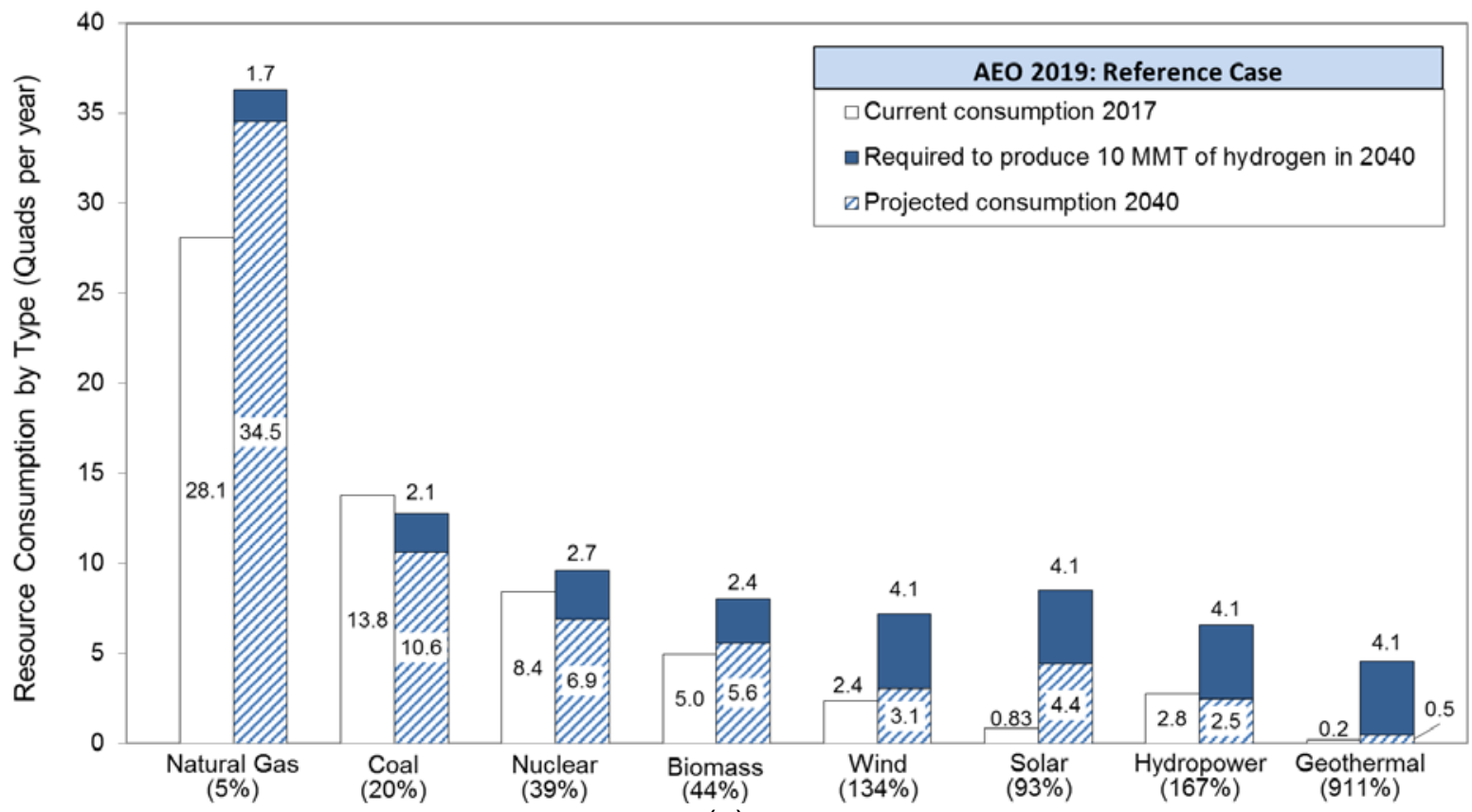

(a)

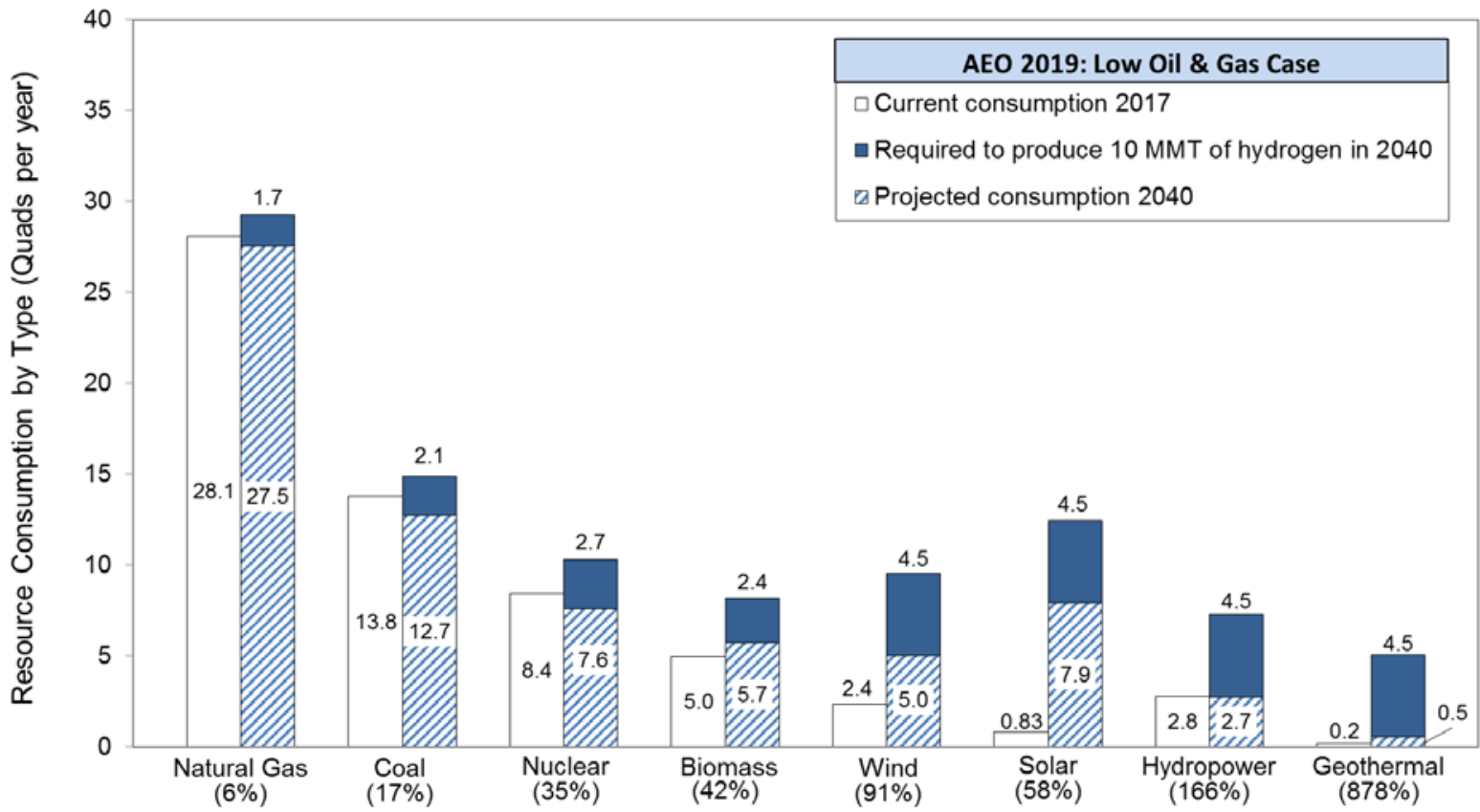

(b)

Figure 19. Comparison of energy resource required to produce 10 MMT hydrogen to current and projected energy consumption from the Annual Energy Outlook Reference Case (a) and Low Oil and Gas Resource and Technology scenario (b).

Energy required to produce $10 \mathrm{MMT}$ of hydrogen is shown as a stacked bar on top of the 2040 AEO2019 Reference Case consumption values (a) and Low Oil and Gas Resource and Technology scenario values (b). For wind, solar, hydropower, and geothermal, the EIA fossil fuel heat rates for electricity net generation of 8,017 Btu/kWh (Reference) and 8,858 Btu/kWh (Low Oil and Gas) were used to convert to quads (EIA 2019f). The percentage increase in consumption for each resource is shown in parentheses. Values are roughly equivalent to those shown in Table 7 and Table 8, with small rounding differences. 


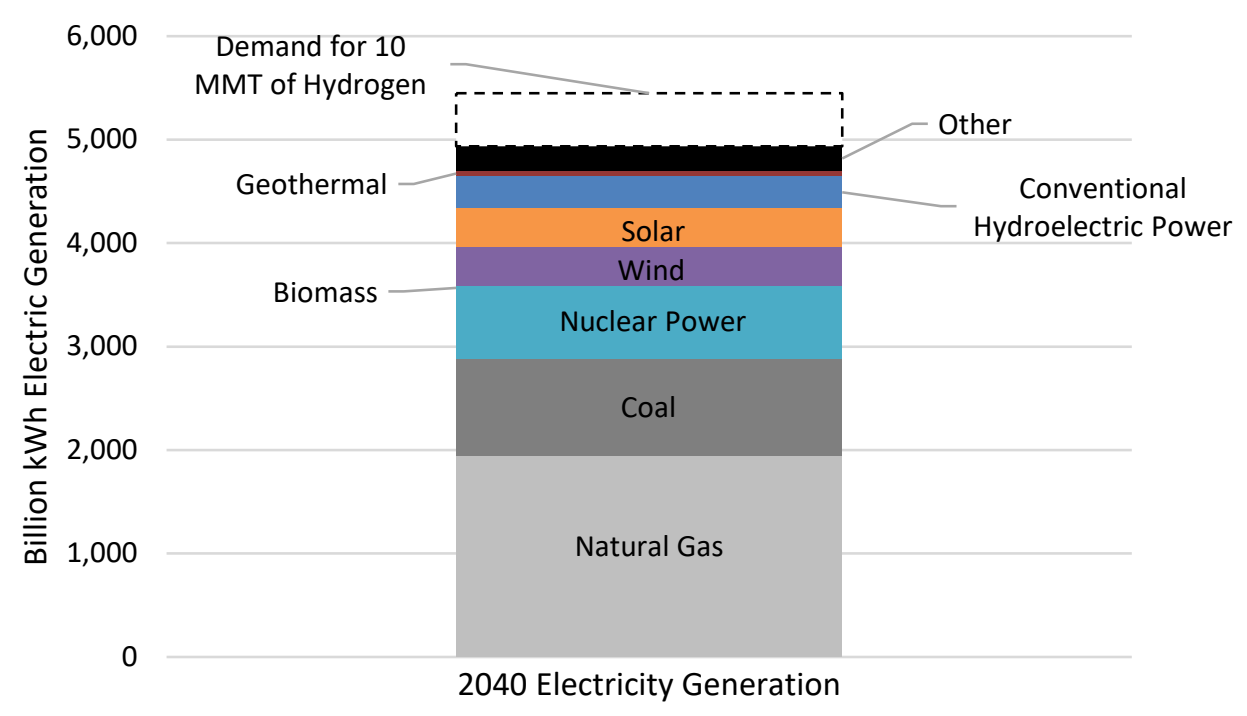

Figure 20. Comparison of electricity demand to produce 10 MMT of hydrogen via LTE and the 2040 projected electricity generation (EIA 2019a)

\section{Water Resource Requirements}

As noted in the 2013 Resource Report, regional water availability may be a limiting factor for hydrogen production. Recent work (Boulay et al. 2018) has developed the available water remaining (AWARE) characterization factor, to reflect regional water scarcity footprint, as part of the United Nations Environment Programme and Society of Environmental Toxicology and Chemistry (UNEP-SETAC) Life Cycle Initiative. The AWARE characterization factor is calculated as the freshwater supply minus both the human and environmental demands for freshwater, by region. This framework enables a comparison of water impacts across regions, globally.

The AWARE framework was developed for global water supply chain analysis. Lee et al. (2019) have developed AWARE-US with a higher spatial resolution and fidelity for the United States to enable decision making at the local level, such as regarding energy system deployment within the United States. Figure 21 shows the county-level AWARE-US characterization factors, where counties that appear as white have a water stress level lower than the U.S. average and counties that appear as red experience water scarcity (Lee et al. 2019). Implied by the AWARE-US characterization factors shown here, hydrogen production would place relatively more strain on water resources if produced in or by resources located in the middle and southwestern regions of the country, depending on the location of displaced water consumption (e.g., gasoline or diesel production, if hydrogen is used for fuel cell vehicles). 


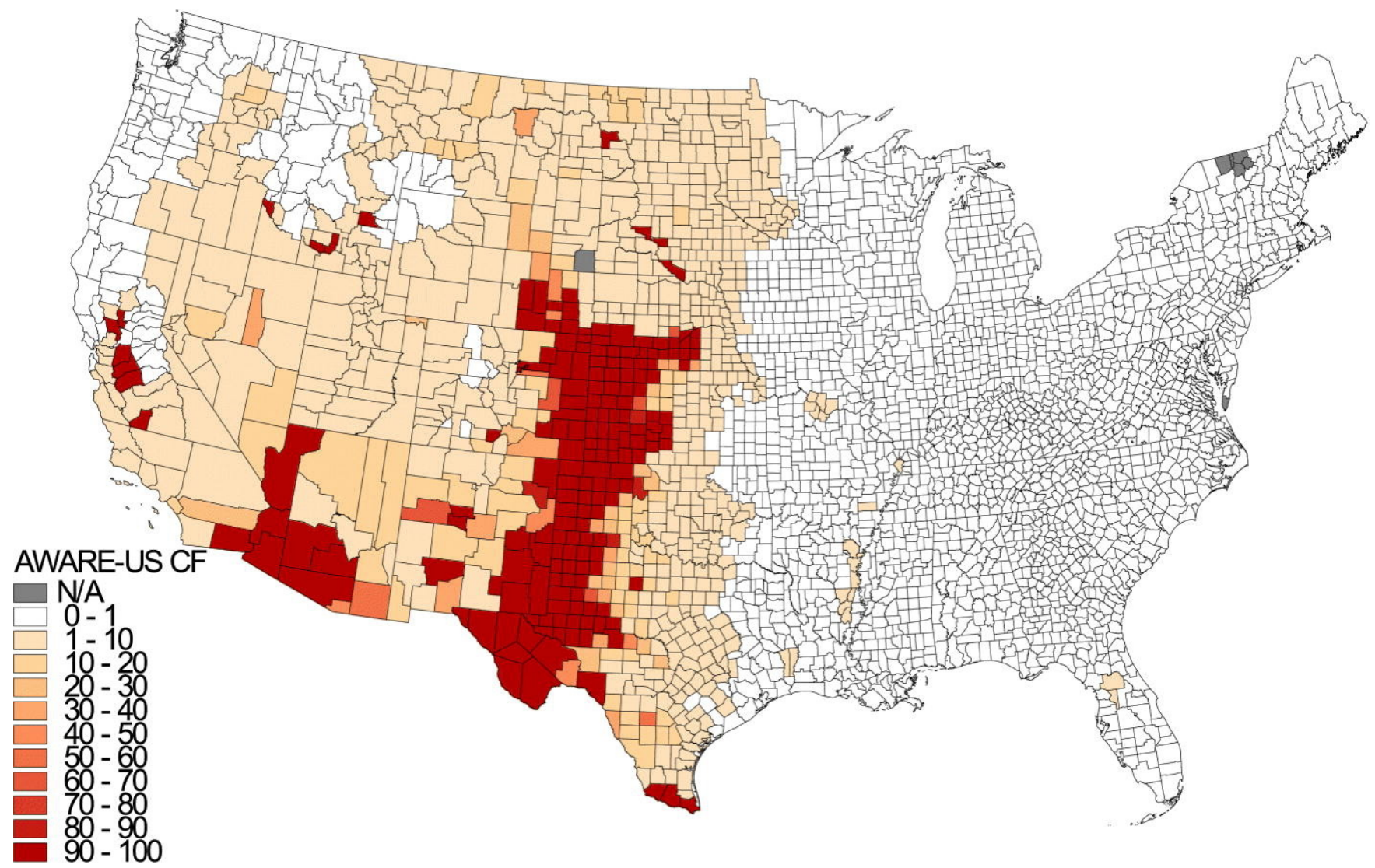

Figure 21. AWARE-US characterization factors by county

Characterization factors $<1$ (shown in white) represent water stress levels lower than the U.S. average, while factors $>1$ (shown in shades of red) represent higher than average water stress levels. Source: Lee et al. 2019, Figure 2(a).

Assessing the impact of regional water scarcity is outside the scope of this analysis and is suggested as possible future research. Here, we present both the direct water consumption for hydrogen production, by technology, as well as the upstream water consumption. As shown in Figure 22, HTE requires the least direct water consumption for hydrogen production. Distributed $\mathrm{LTE}^{17}$ and natural gas steam methane reforming (SMR) are also expected to require less than 3 gallons per kilogram of hydrogen produced. The direct water consumption will take place at the point of hydrogen production, which may or may not be at the same location of the resources. For example, biomass may be transported some distance to a centralized gasification plant, meaning upstream and direct water consumption do not occur at the same location. Upstream water consumption, related to resource recovery or farming, will also influence the water impacts of hydrogen production.

\footnotetext{
${ }^{17}$ Centralized LTE has a higher water consumption than distributed due to cooling requirements. See Table 9 of Han and Elgowainy (2017).
} 


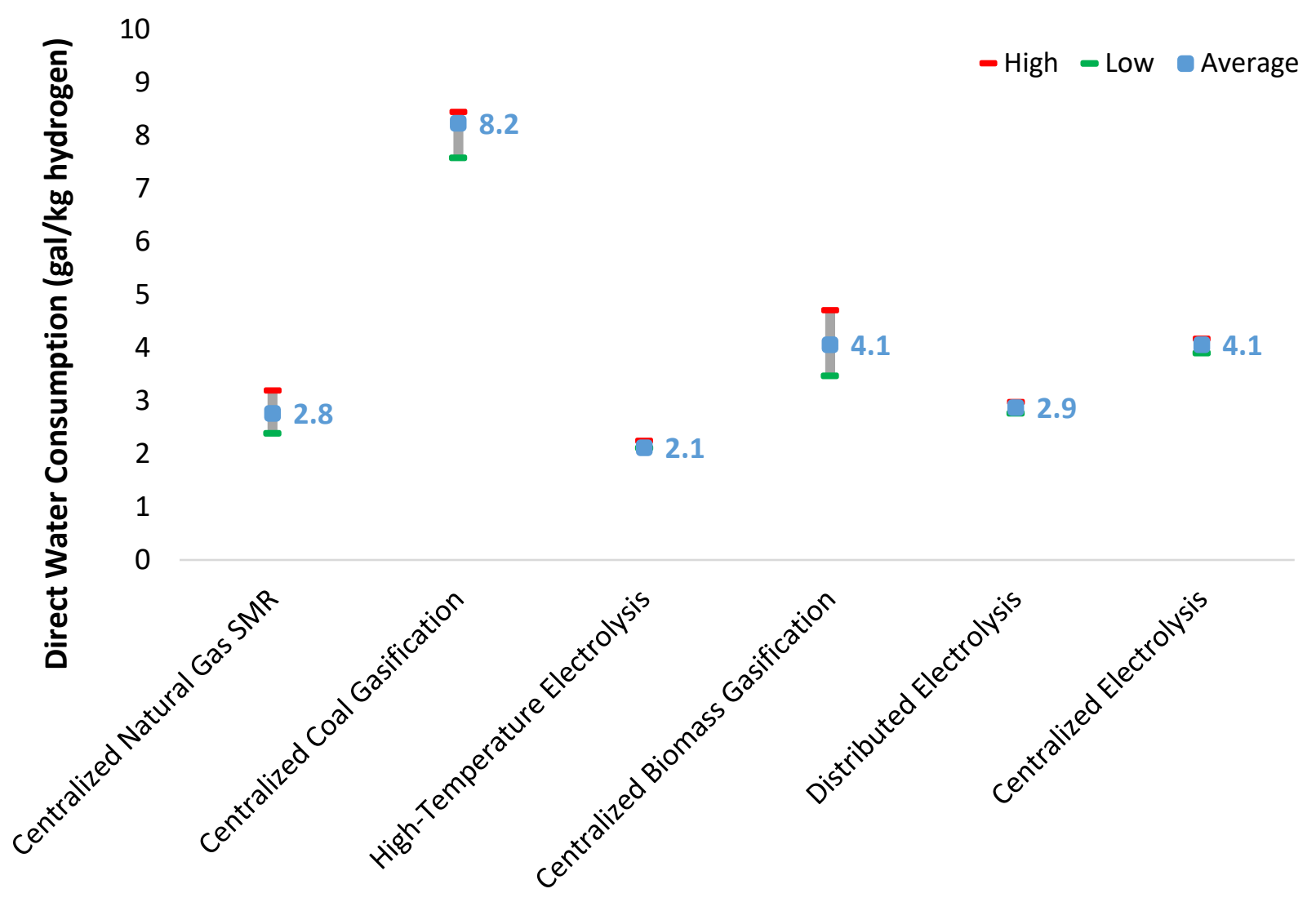

Hydrogen Production Process

Figure 22. Comparison of direct water consumption for hydrogen production across technologies Source: Han and Elgowainy (2017) and GREET Model (ANL 2019)

The estimated upstream water consumption for feedstock production or recovery and transport is added to the direct water consumption for each of the hydrogen pathways, as shown in Figure 23. The upstream water consumption for some pathways, such as nuclear HTE and geothermal, dominate the total water needs. Evaporative losses are excluded from the hydropower upstream water consumption, though these would influence regional water impacts. ${ }^{18}$

Wind and hydropower-based hydrogen production requires the least water consumption, followed by natural gas SMR. In addition, coal and biomass gasification and solar electrolysis require a total of less than $10 \mathrm{gal} / \mathrm{kg}$ hydrogen. The water consumption for biomass production, however, depends largely on the feedstock. The figure represents only the biomass feedstocks for hydrogen production that are considered in the GREET model, ${ }^{19}$ which varies by feedstock.

The baseline upstream water consumption for geothermal LTE assumes flash plants for electricity production. The error bars represent the water consumption for EGS (low) and binary

\footnotetext{
${ }^{18}$ There is considerable variability in the upstream water consumption of hydropower due to reservoir surface area and regional climate, as described further in Lee et al. (2017).

${ }^{19}$ The upstream water consumption for biomass is based on the range across the following feedstocks included in the GREET hydrogen modeling: corn stover, willow, poplar, switchgrass, forest residue, and miscanthus.
} 
plants (high). These values differ somewhat from the assumptions in the GeoVision analysis (see Figure 9 of Millstein et al. 2019)

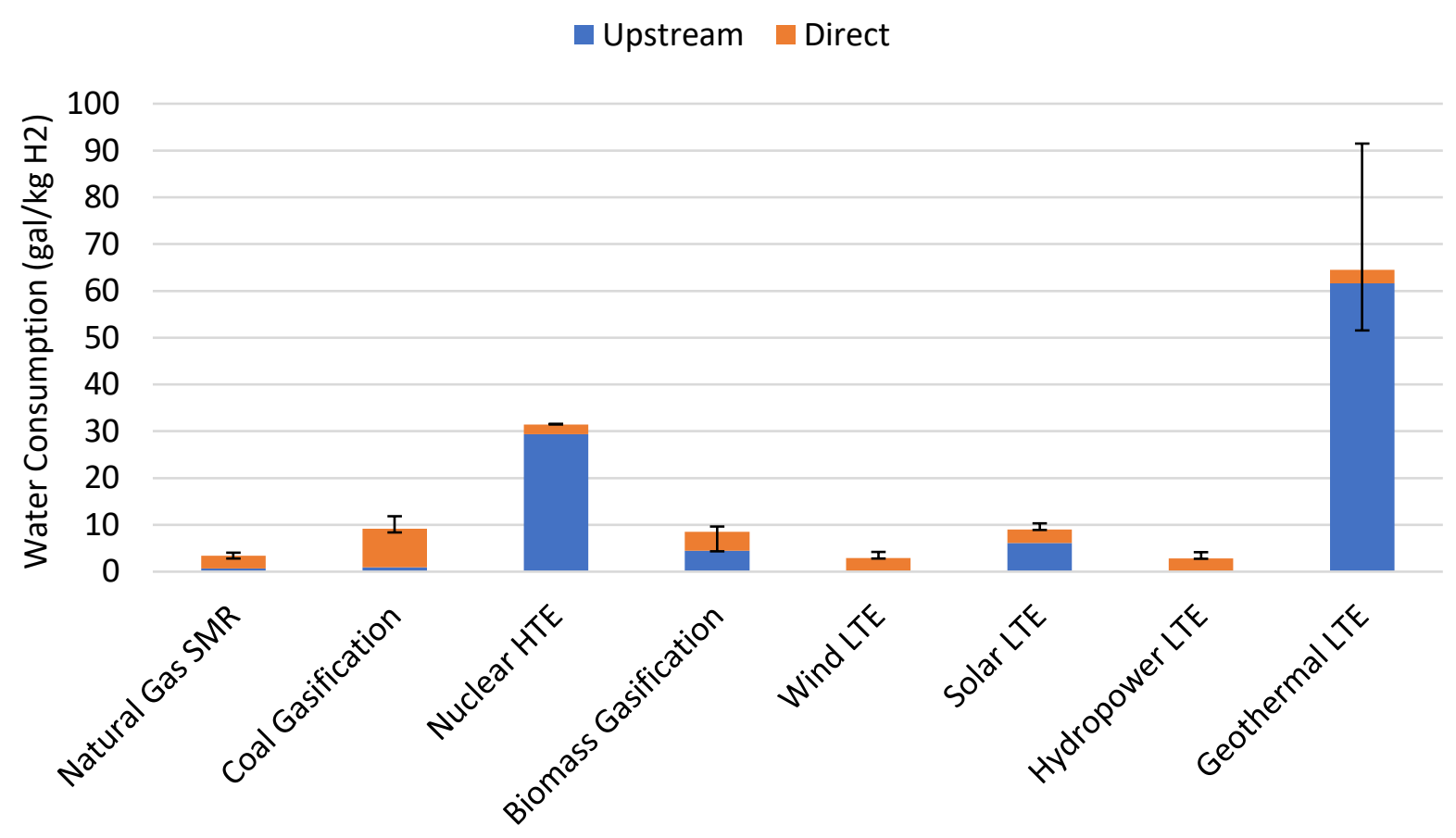

Figure 23. Upstream and direct water consumption by hydrogen production pathway

The production of 10 MMT of hydrogen, excluding indirect consumption for transport, distribution, and end use, would require between approximately 29 billion gallons (if produced exclusively from wind) and 645 billion gallons (if produced exclusively from geothermal) of water. For context, in 2015, the estimated freshwater withdrawal in the United States was over 100 trillion gallons (Dieter et al. 2018). Thus, the water requirement to produce $10 \mathrm{MMT}$ of hydrogen would range from approximately $<0.03 \%$ to $0.6 \%$ of the U.S. freshwater withdrawals, not considering displacement based on the end use of the hydrogen (e.g., displacement of gasoline or diesel for vehicles).

\section{Comparison of Fixed and Flow Energy Potential Estimates}

Table 9 compares the technical hydrogen production potentials for fossil and nuclear resources. Table 10 compares the annual technical hydrogen production potentials for renewable resources. Influential parameters, such as conversion efficiency, are subject to change over time due to technological advances and other emergent conditions, impacting estimates and the relative comparison of hydrogen production potentials of different energy resources. The estimates in Table 9 and Table 10 are shown in terms of both physical resource units and as total hydrogen production potential in MMT hydrogen and quads. Renewable potentials are presented on an annual basis whereas fossil and nuclear potentials are fixed estimates.

As was shown in Figure 1, the U.S. coal reserves are greater than both natural gas and uranium on an energy basis. As a result, coal has the highest hydrogen production potential of the finite resources. The annual technical hydrogen production potential of solar resources actually 
exceeds the total potential from uranium resources. It is important to note, however, that due to data limitations, the uranium resource and corresponding hydrogen production potential is likely an underestimate.

Water power resources appear to have the lowest hydrogen production potential of all renewable resources, especially if MHK is not considered. Including potential from MHK results in both water power and biomass resources with similar hydrogen production potentials, approximately 50 MMT per year. Regardless, each of the renewable resources assessed has the potential to produce over $10 \mathrm{MMT}$ per year of hydrogen in the absence of competition for the resources.

Table 9. Hydrogen Production Potential from Finite Resources

\begin{tabular}{|l|l|l|l|l|l|l|}
\hline Resource & \multicolumn{4}{|c}{ Resource Potential } & \multicolumn{3}{l|}{ Hydrogen Production Potential } \\
\hline Fossil and Nuclear & Physical Resource & Quads & Hydrogen Potential & Quads $\mathrm{H}_{\mathbf{2}}$ \\
\hline Natural Gas & 2,800 & Trillion cubic feet & 2,600 & 17,800 & MMT H$_{2}$ & 2,100 \\
\hline Coal & 470 & Billion short tons & 9,500 & 50,100 & MMT H$_{2}$ & 6,800 \\
\hline Uranium & 400 & Million $\mathrm{Ib} \mathrm{U}_{3} \mathrm{O}_{8}$ & 700 & 2,900 & MMT H$_{2}$ & 300 \\
\hline
\end{tabular}

Notes: Conversions to quads are on an HHV basis; sums are rounded.

Table 10. Annual Hydrogen Production Potential from Renewable Resources

\begin{tabular}{|c|c|c|c|c|c|c|}
\hline \multirow{3}{*}{$\begin{array}{l}\text { Resource } \\
\text { Renewable } \\
\text { Biomass }\end{array}$} & \multicolumn{3}{|c|}{ Resource Potential } & \multicolumn{3}{|c|}{$\begin{array}{c}\text { Hydrogen Production } \\
\text { Potential }\end{array}$} \\
\hline & \multicolumn{2}{|c|}{ Annual Physical Resource } & \multirow{2}{*}{\begin{tabular}{|l|} 
Quads/yr \\
12 \\
\end{tabular}} & \multicolumn{2}{|c|}{$\begin{array}{l}\text { Annual Hydrogen } \\
\text { Potential }\end{array}$} & \multirow{2}{*}{$\begin{array}{l}\text { Quads } \\
\mathrm{H}_{2} / \mathbf{y r} \\
7 \\
\end{array}$} \\
\hline & 800 & Million tons eq./yr & & 50 & MMT $\mathrm{H}_{2} / \mathrm{yr}$ & \\
\hline Wind & 37,800 & TWh electricity/yr & 400 & 700 & MMT $\mathrm{H}_{2} / \mathrm{yr}$ & 100 \\
\hline Solar & 261,800 & TWh electricity/yr & 2,400 & 5,100 & MMT $\mathrm{H}_{2} / \mathrm{yr}$ & 700 \\
\hline $\begin{array}{l}\text { Hydropower } \\
\text { (conventional) }\end{array}$ & 690 & TWh electricity/yr & 6 & 14 & MMT $\mathrm{H}_{2} / \mathrm{yr}$ & 2 \\
\hline $\begin{array}{l}\text { Water Power } \\
\text { (including MHK) }\end{array}$ & 2,500 & TWh electricity/yr & 20 & 50 & MMT $\mathrm{H}_{2} / \mathrm{yr}$ & 7 \\
\hline $\begin{array}{l}\text { Geothermal } \\
\text { (conventional) }\end{array}$ & 180 & TWh electricity/yr & 2 & 4 & MMT $\mathrm{H}_{2} / \mathrm{yr}$ & 1 \\
\hline $\begin{array}{l}\text { Geothermal } \\
\text { (including EGS) }\end{array}$ & 24,800 & TWh electricity/yr & 230 & 480 & MMT $\mathrm{H}_{2} / \mathrm{yr}$ & 60 \\
\hline
\end{tabular}




\section{Conclusions}

This report provides an update to the 2013 assessment of energy resources required to produce hydrogen to meet a demand of 10 MMT of hydrogen in 2040 (Melaina et al. 2013). We estimate the requirements for a single resource to meet hydrogen demand in this scenario, which represents a doubling of current hydrogen demand. Such significant growth in the hydrogen economy would likely require government support, especially related to research, development, and demonstration efforts.

The technical potentials of energy resources for producing hydrogen have been updated based on analyses performed since the publication of the 2013 Resource Report. The updated results are largely consistent with the previous findings, in terms of high-level conclusions: there are ample domestic resources available to supply hydrogen to meet future demand.

One of the most significant differences in this report compared to the 2013 Resource Report is a $50 \%$ reduction in EIA's 2040 projected coal consumption (from 20.6 to 10.6 quads) in the Reference Case. Also accounting for an update to the coal-to-hydrogen conversion rate, the percent increase in coal consumption to meet hydrogen demand of $10 \mathrm{MMT} /$ year increases from $13 \%$ (in the 2013 Resource Report) to 20\%. In addition, this update shows an increase in the technical potential of natural gas resources.

As described, there are major uncertainties associated with U.S. uranium resource estimates, and a thorough evaluation of the U.S. uranium resource base has not been conducted since 1980 (NEA-IAEA 2016). In addition, advanced reactor designs are expected to increase hydrogen production from nuclear energy. Thus, the results presented here are likely an underestimate of the true technical hydrogen production potential from nuclear.

The updated technical potential of solar is significantly lower than that previously reported, though it still results in a hydrogen production potential of over 5,000 MMT/year. The increase in EIA's projected 2040 solar and wind consumption results in a reduction in the percent increase in solar and wind necessary to meet $10 \mathrm{MMT} /$ year of hydrogen demand. This update also reveals how water power and geothermal resources could increase renewable hydrogen production potential by almost $600 \mathrm{MMT} /$ year (combined), depending on technological progress. Updated maps of renewable hydrogen production potential have been provided for solid and gaseous biomass, wind, solar, and water power; data to map geothermal technical potential are not currently available.

An online data-sharing and visualization tool (HyDRA, https://maps.nrel.gov/hydra/) is currently under development and will serve to provide the spatial resource assessment results. Other future work may consist of:

- Estimating economic potential of hydrogen production from domestic energy resources

- Accounting for water availability constraints

- Incorporating resource potential estimates into the Scenario Evaluation and Regionalization Analysis (SERA) model (Bush et al. 2013) for cost-based optimization of hydrogen supply chains. 
Such future work will contribute to the spatial planning of hydrogen production based on resource availability, final demand locations, water constraints, and cost of infrastructure. 


\section{References}

Argonne National Laboratory (2019). The Greenhouse Gases, Regulated Emissions, and Energy Use in Transportation (GREET®) Model v 2019. https://greet.es.anl.gov/index.php.

Augustine, C., Ho, J., Blair, N. (2019). GeoVision Analysis Supporting Task Force Report: Electric Sector Potential to Penetration. Golden, CO: National Renewable Energy Laboratory. NREL/ TP-6A20-71833. https://www.nrel.gov/docs/fy19osti/71833.pdf.

Boulay, A.M., Bare, J., Benini, L., Berger, M., Lathuillière, M.J., Manzardo, A., Margni, M., Motoshita, M., Núñez, M., Pastor, A.V., Ridoutt, B. (2018). "The WULCA consensus characterization model for water scarcity footprints: assessing impacts of water consumption based on available water remaining (AWARE)." The International Journal of Life Cycle Assessment 23 (2): 368-378.

Brown, L.C., Besenbruch, G.E., Lentsch, R.D., Schultz, K.R., Funk, J.F., Pickard, P.S., Marshall, A.S., Showalter, S.K. (2003). "High efficiency generation of hydrogen fuels using nuclear power General Atomics." GA-A24285.

Bunn, M., Fetter, S., Holdren, J.P., van der Zwaan, B. (2003). The Economics of Reprocessing vs. Direct Disposal of Spent Nuclear Fuel-Final Report; DE-FG26-99FT4028; Harvard University: Cambridge, MA, USA.

Bush, B., Melaina, M., Penev, M., Daniel, B. (2013). SERA Scenarios of Early Market Fuel Cell Electric Vehicle Introductions: Modeling Framework, Regional Markets, and Station Clustering. National Renewable Energy Laboratory, Technical Report NREL/TP-5400-56588, available online: http://www.nrel.gov/docs/fy13osti/56588.pdf.

Chao, J. (2016). Water-Energy Nexus New Focus of Berkeley Lab Research.

http://newscenter.lbl.gov/2016/05/23/water-energy-nexus-new-focus-berkeley-lab-research/.

Connelly, E., Elgowainy, A., Ruth, M. (2019). "Current Hydrogen Market Size: Domestic and Global.” DOE Hydrogen and Fuel Cells Program Record \#19002.

https://www.hydrogen.energy.gov/pdfs/19002-hydrogen-market-domestic-global.pdf.

Dieter, C.A., Maupin, M.A., Caldwell, R.R., Harris, M.A., Ivahnenko, T.I., Lovelace, J.K., Barber, N.L., Linsey, K.S. (2018). Estimated use of water in the United States in 2015: U.S. Geological Survey Circular 1441, 65 p., https://doi.org/10.3133/cir1441.

DOE. (2011). The Department of Energy Hydrogen and Fuel Cells Program Plan. U.S. Department of Energy, Fuel Cell Technologies Office.

DOE. (2012). H2A Analysis, U.S. Department of Energy, Fuel Cell Technologies Office, http://www.hydrogen.energy.gov/h2a analysis.html.

DOE. (2015). Quadrennial Technology Review 2015. Chapter TA 4.N: Marine and Hydrokinetic Power. https://www.energy.gov/sites/prod/files/2015/12/f27/QTR2015-4N-Marine-andHydrokinetic-Power.pdf. 
DOE. (2016). 2016 Billion-Ton Report: Advancing Domestic Resources for a Thriving Bioeconomy, Volume 1: Economic Availability of Feedstocks. M.H. Langholtz, B.J. Stockes, and L.M. Eaton (Leads), ORNL/TM-2016/160. Oak Ridge National Laboratory, Oak Ridge, TN. 448p. doi: 10.2172/1271651. http://energy.gov/eere/bioenergy/2016-billion-ton-report.

DOE. (2019). GeoVision: Harnessing the Heat Beneath Our Feet. https://www.energy.gov/eere/geothermal/downloads/geovision-harnessing-heat-beneath-our-feet.

DOE. (2020). "Hydrogen Production Cost From PEM Electrolysis - 2019." DOE Hydrogen and Fuel Cells Program Record 19009. https://www.hydrogen.energy.gov/pdfs/19009_h2_production_cost_pem_electrolysis_2019.pdf.

EIA. (2012). Annual Energy Review 2011. DOE/EIA-0384(2011). https://www.eia.gov/totalenergy/data/annual/archive/038411.pdf.

EIA. (2015). Top 100 U.S. Oil and Gas Fields. https://www.eia.gov/naturalgas/crudeoilreserves/top100/pdf/top100.pdf.

EIA. (2016). Annual Coal Report 2015. Table 15. Recoverable Coal Reserves at Producing Mines, Estimated Recoverable Reserves, and Demonstrated Reserve Base by Mining Method, 2015. https://www.eia.gov/coal/annual/archive/05842015.pdf.

EIA. (2017a). Annual Coal Report 2016. Table 15. Recoverable Coal Reserves at Producing Mines, Estimated Recoverable Reserves, and Demonstrated Reserve Base by Mining Method, 2016. https://www.eia.gov/coal/annual/archive/05842016.pdf.

EIA. (2017b). Assumptions to the Annual Energy Outlook. Table 9.2 Technically recoverable U.S. dry natural gas resources as of January 1, 2014. https://www.eia.gov/outlooks/aeo/assumptions/pdf/0554(2016).pdf.

EIA. (2017c). 2015 Domestic Uranium Production Report. Table 10. Uranium reserve estimates at the end of 2014 and 2015.

https://www.eia.gov/uranium/production/annual/archive/dupr2015.pdf.

EIA. (2017d). Monthly Energy Review. Table A5. Approximate Heat Content of Coal and Coal Coke. U.S. Energy Information Administration, August 2017. https://www.eia.gov/totalenergy/data/monthly/pdf/sec13 6.pdf.

EIA. (2017e). Monthly Energy Review. Table A4. Approximate Heat Content of Natural Gas. U.S. Energy Information Administration, August 2017. https://www.eia.gov/totalenergy/data/monthly/pdf/sec13 5.pdf.

EIA. (2017f). 2016 Uranium Marketing Annual Report. https://www.eia.gov/uranium/marketing/pdf/2016umar.pdf.

EIA. (2017g). Electric Power Annual Report. Table 8.1 Average Operating Heat Rate for Selected Energy Sources, 2005 through 2015 (Btu per Kilowatthour).

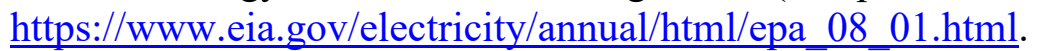


EIA. (2017h). Annual Energy Outlook 2017. Table: Energy Consumption by Sector and Source. https://www.eia.gov/outlooks/aeo/data/browser/\#/?id=2-AEO2017\&region=1$\underline{0 \text { \&cases }}=\mathrm{ref} 2017 \sim$ lowrt\&start $=2015 \&$ end $=2050 \& \mathrm{f}=$ A\&sourcekey $=0$.

EIA. (2017i). Annual Energy Outlook 2017 with projections to 2050. Projections Tables for Side Cases: Renewable Energy Consumption by Sector and Source, Low oil and natural gas resource and technology scenario. https://www.eia.gov/outlooks/aeo/tables_side.php.

EIA. (2017j). Annual Energy Outlook 2017. Table: Transportation Sector Key Indicators and Delivered Energy Consumption. https://www.eia.gov/outlooks/aeo/data/browser/\#/?id=7$\underline{\mathrm{AEO} 2017 \& \text { cases }=\mathrm{ref} 2017 \& \text { sourcekey }=0 \text {. }}$.

EIA. (2018a). Natural Gas. Natural Gas Reserves Summary as of Dec. 31. https://www.eia.gov/dnav/ng/ng enr sum dcu NUS a.htm.

EIA. (2018b). Monthly Energy Review September 2018. Table A4. Approximate Heat Content of Natural Gas. https://www.eia.gov/totalenergy/data/monthly/pdf/sec13 4.pdf.

EIA. (2018c). 2017 Domestic Uranium Production Report. Table 10. Uranium reserve estimates at the end of 2016 and 2017. https://www.eia.gov/uranium/production/annual/pdf/dupr.pdf.

EIA. (2018d). Assumptions to the Annual Energy Outlook 2018: Oil and Gas Supply Module. Table 2. Technically recoverable U.S. dry natural gas resources as of January 1, 2016. https://www.eia.gov/outlooks/aeo/assumptions/pdf/oilgas.pdf.

EIA. (2018d). Annual Coal Report. Table 15. Recoverable Coal Reserves at Producing Mines, Estimated Recoverable Reserves, and Demonstrated Reserve Base by Mining Method, 2017. https://www.eia.gov/coal/annual/archive/05842017.pdf.

EIA. (2019a). Annual Energy Outlook 2019. https://www.eia.gov/outlooks/aeo/.

EIA. (2019b). Annual Coal Report 2018. https://www.eia.gov/coal/annual/.

EIA. (2019c). 2018 Domestic Uranium Production Report.

https://www.eia.gov/uranium/production/annual/pdf/dupr.pdf.

EIA. (2019d). 2018 Uranium Marketing Annual Report

https://www.eia.gov/uranium/marketing/pdf/umar2018.pdf.

EIA. (2019e). Table 8.1. Average Operating Heat Rate for Selected Energy Sources. https://www.eia.gov/electricity/annual/html/epa_08_01.html.

EIA. (2019f). Annual Energy Outlook 2019. Average Fossil Fuel Heat Rates for Electricity Generation. https://www.eia.gov/outlooks/archive/aeo19/heat rates.php.

EIA. (2019g). Annual Energy Outlook 2019. Table: Renewable Energy Generating Capacity and Generation. https://www.eia.gov/outlooks/aeo/data/browser/\#/?id=16-

$\underline{\mathrm{AEO} 2019 \& \text { cases }=\mathrm{ref} 2019 \& \text { sourcekey }=0}$. 
EIA. (2020). "Hydrogen explained: Production of hydrogen."

https://www.eia.gov/energyexplained/hydrogen/production-of-hydrogen.php.

EIA. (2020a). Assumptions to the Annual Energy Outlook. Table 2. Technically recoverable U.S. dry natural gas resources as of January 1, 2018.

https://www.eia.gov/outlooks/aeo/assumptions/pdf/oilgas.pdf.

EIA. (2020b). Monthly Energy Review. Table A4. Approximate Heat Content of Natural Gas. U.S. Energy Information Administration, March 2020.

https://www.eia.gov/totalenergy/data/monthly/pdf/sec12 5.pdf.

EIA. (2020c). Monthly Energy Review. Table A5. Approximate Heat Content of Coal and Coal Coke. U.S. Energy Information Administration, March 2020.

https://www.eia.gov/totalenergy/data/monthly/pdf/sec12 6.pdf.

Elgowainy, A., Han, J., Lee, U., Li, J., Dunn, J., Wang, M. (2016). “Life-Cycle Analysis of Water Consumption for Hydrogen Production." 2016 DOE Hydrogen and Fuel Cells Program Annual Merit Review - SA039.

https://www.hydrogen.energy.gov/pdfs/review16/sa039_elgowainy_2016_o.pdf.

Gagnon, P., Margolis, R., Melius, J., Phillips, C., Elmore, R. (2016). Rooftop Solar Photovoltaic Technical Potential in the United States: A Detailed Assessment. National Renewable Energy Laboratory. https://www.nrel.gov/docs/fy16osti/65298.pdf.

Hadjerioua, B., Wei, Y., Kao, S.-C. (2012). An Assessment of Energy Potential at Non-Powered Dams in the United States. Oak Ridge National Laboratory https://hydrosource.ornl.gov/sites/default/files/NHAAP_NPD_FY11_Final_Report.pdf.

Han, J., Elgowainy, A. (2017). “Water Consumption for Light-Duty Vehicles' Transportation Fuels.” Program Record 17005.

https://www.hydrogen.energy.gov/pdfs/17005 water_consumption_ldv fuels.pdf.

Johnson et al. (2019). "Existing Hydropower Assets." HydroSource. Oak Ridge National Laboratory, Oak Ridge, TN. https://hydrosource.ornl.gov/market-info-and-data/existinghydropower-assets.

Kao et al. (2014). New Stream-Reach Development: A Comprehensive Assessment of Hydropower Energy Potential in the United States. Oak Ridge National Laboratory. https://hydrosource.ornl.gov/sites/default/files/ORNL_NSD_FY14_Final_Report.pdf.

Lee, U., Han, J., Elgowainy, A., Wang, M. (2017) "Regional water consumption for hydro and thermal electricity generation in the United States." Applied Energy 210: 661-672. https://doi.org/10.1016/j.apenergy.2017.05.025.

Lee, U., Xu, H., Daystar, J., Elgowainy, A., Wang, M. (2019). “AWARE-US: Quantifying water stress impacts of energy systems in the United States." Science of the Total Environment 648: 1313-1322. 
Lopez, A., Roberts, B., Heimiller, D., Blair, N., Porro, G. (2012). U.S. Renewable Energy Technical Potentials: A GIS-Based Analysis. NREL/TP-6A20-51946. Golden, CO: National Renewable Energy Laboratory.

Maclaurin, G., Grue, N., Lopez, A., Heimiller, D. (2019). The Renewable Energy Potential (reV) Model: A Geospatial Platform for Technical Potential and Supply Curve Modeling. NREL/TP6A20-73067. Golden, CO: National Renewable Energy Laboratory. https://www.nrel.gov/docs/fy19osti/73067.pdf.

Mann, M., Steward, D. (2018). H2A version 3. Future Central Hydrogen from Biomass via Gasification and Catalytic Steam Reforming. https://www.nrel.gov/hydrogen/assets/docs/futurecentral-biomass-gasification-v3-2018.xlsm.

Melaina, M., Penev, M., Heimiller, D. (2013). Resource Assessment for Hydrogen Production: Hydrogen Production Potential from Fossil and Renewable Energy Resources. NREL/TP-540055626. Golden, CO: National Renewable Energy Laboratory.

Meldrum, J., Nettles-Anderson, S., Heath, G., Macknick J. (2013). "Life cycle water use for electricity generation: a review and harmonization of literature estimates." Environmental Research Letters 8: 015031.

Milbrandt, A., Mann, M. (2007). Potential for Hydrogen Production from Key Renewable Resources in the United States. NREL/TP-640-41134. Golden, CO: National Renewable Energy Laboratory.

Milbrandt, A.; Mann, M. (2009). Hydrogen Resource Assessment: Hydrogen Potential from Coal, Natural Gas, Nuclear, and Hydro Power. NREL/TP-560-42773. Golden, CO: National Renewable Energy Laboratory.

Milbrandt, A., Seiple, T., Heimiller, D., Skaggs, R., Coleman, A. (2018). "Wet waste-to-energy resources in the United States." Resources, Conservation and Recycling 137: 32-47. https://www.sciencedirect.com/science/article/pii/S0921344918301988.

Millstein, D., McCall, J., Macknick, J., Nicholson, S., Keyser, D., Jeong, S., Heath, G. (2019). GeoVision Analysis Supporting Task Force Report: Impacts-The Employment Opportunities, Water Impacts, Emission Reductions, and Air Quality Improvements of Achieving High Penetrations of Geothermal Power in the United States. Berkeley, CA and Golden, CO: Lawrence Berkeley National Laboratory and National Renewable Energy Laboratory. NREL/TP6A20-71933. https://www.nrel.gov/docs/fy19osti/71933.pdf and https://emp.lbl.gov/publications/geovision-analysis-impacts-task-force.

Murphy, C., Sun, Y., Cole, W., Maclaurin, G., Turchi, C., Mehos, M. (2019). The Potential Role of Concentrating Solar Power within the Context of DOE's 2030 Solar Cost Targets. National Renewable Energy Laboratory. https://www.nrel.gov/docs/fy19osti/71912.pdf. 
NEA-IAEA. (2016). "Uranium 2016 - Resources, Production and Demand." Nuclear Energy Agency and International Atomic Energy Agency, Organization for Economic Co-operation and Development Publishing, NEA No. 7301. http://www.oecd-nea.org/ndd/pubs/2016/7301uranium-2016.pdf.

NEA-IAEA. (2018). "Uranium 2018 - Resources, Production and Demand." Nuclear Energy Agency and International Atomic Energy Agency, Organization for Economic Co-operation and Development Publishing, NEA No. 7413. https://www.oecd-nea.org/ndd/pubs/2018/7413uranium-2018.pdf.

National Energy Technology Laboratory (NETL). (2010). Assessment of Hydrogen Production with $\mathrm{CO}_{2}$ Capture - Volume 1: Baseline State-of-the-Art Plants. DOE/NETL-2010/1434. http://www.canadiancleanpowercoalition.com/pdf/SMR9\%20-\%20H2_Prod_Vol1_2010.pdf.

National Renewable Energy Laboratory (NREL). (2012). Renewable Electricity Futures Study. Hand, M.M., Baldwin, S., DeMeo, E., Reilly, J.M., Mai, T., Arent, D., Porro, G., Meshek, M., Sandor, D. eds. 4 vols. NREL/TP-6A20-52409. Golden, CO: National Renewable Energy Laboratory. https://www.nrel.gov/analysis/re-futures.html.

National Renewable Energy Laboratory (NREL). (2013). Biomass Research website, available at: https://www.nrel.gov/bioenergy/index.html.

National Renewable Energy Laboratory (NREL). (2017). Renewable Energy Potential (reV) model. Publication forthcoming.

National Renewable Energy Laboratory. (2019). 2019 Annual Technology Baseline. Golden, CO: National Renewable Energy Laboratory. https://atb.nrel.gov/electricity/2019.

O’Brien, J. (2014). "High Temperature Electrolysis forEfficient Hydrogen Production from Nuclear Energy - INL Research Program Summary.” Electrolytic Hydrogen Production Workshop, National Renewable Energy Laboratory, Golden, CO, February 27-28, 2014. https://www.energy.gov/sites/prod/files/2014/08/f18/fcto_2014_electrolytic_h2_wkshp_obrien1. pdf.

O’Brien, J. (2017) Personal Communication. See Appendix A.

Ruth, M., Mai, T., Newes, E., Aden, A., Warner, E., Uriarte, C., Inman, D., Simpkins, T., Argo, A. (2013). Projected Biomass Utilization for Fuels and Power in a Mature Market.

Transportation Energy Futures Series. Prepared for the U.S. Department of Energy by National Renewable Energy Laboratory, Golden, CO. DOE/GO-102013-3707. 153 pp.

USGS. (2017). Integrated Uranium Resource and Environmental Assessment. https://www.usgs.gov/media/images/figure-uranium-resources-united-states.

USGS. (2020). Assessment Summary Maps/Tables. USGS Domestic Continuous (Unconventional) Oil \& Gas Assessments, 2000-2018.

https://certmapper.cr.usgs.gov/data/apps/noga-summary/. 
Van Gosen, B.S., Gillerman, V.S., Armbrustmacher, T.J. (2009). Thorium deposits of the United States- Energy resources for the future?: U.S. Geological Survey Circular 1336, 21 p. [Only available at URL http://pubs.usgs.gov/circ/1336].

Wang, M. (2012). GREET ${ }^{\circledR}$ Software, 2018 release.

https://greet.es.anl.gov/index.php?content=download1x.

World Nuclear Association. (2017). The Nuclear Fuel Cycle. Power generation and burn-up. http://www.world-nuclear.org/information-library/nuclear-fuel-cycle/introduction/nuclear-fuelcycle-overview.aspx. 


\section{Appendix A. Nuclear Calculations}

Figure A-1 describes the assumptions and calculations proved by Jim O'Brien (personal communication, 2017) for the uranium-to-hydrogen ratio for an HTE reactor. The hydrogen production rate is used to calculate the hydrogen production efficiency of the described $600 \mathrm{MWt}$ reactor according to the following equation:

$$
\begin{gathered}
\left(85,000,000 \frac{s c f \mathrm{H}_{2}}{d a y} \times 290 \frac{\mathrm{Btu}}{\mathrm{scf} \mathrm{H}_{2}}\right) /\left(600 \mathrm{MWt} \times 24 \frac{\mathrm{hr}}{\mathrm{day}} \times 3600 \frac{\mathrm{MJ}}{\mathrm{MWh}} \times 947.8 \frac{\mathrm{Btu}}{\mathrm{MJ}}\right) \\
=50.2 \% \text { energy efficiency of hydrogen production (LHV) }
\end{gathered}
$$

where $290 \mathrm{Btu} / \mathrm{scf} \mathrm{H}_{2}$ is the LHV of hydrogen.

To address electrical efficiency, the EIA heat rate of 10,459 Btu/kWh (EIA 2019, average from Table 8.1) is applied to estimate electrical requirements:

$$
\frac{600 \mathrm{MWt} \times 24 \frac{\mathrm{hr}}{d a y} \times \frac{3412.14 \frac{\mathrm{Btu}}{\mathrm{kWh}}}{10,459 \frac{\mathrm{Btu}}{\mathrm{kWh}}} \times 1000 \frac{\mathrm{kWh}}{\mathrm{MWh}}}{85,000,000 \frac{\mathrm{scf}}{d a y} \times 0.00236 \frac{\mathrm{kg}}{s c f}}=23.4 \frac{\mathrm{kWh}}{\mathrm{kg}}
$$




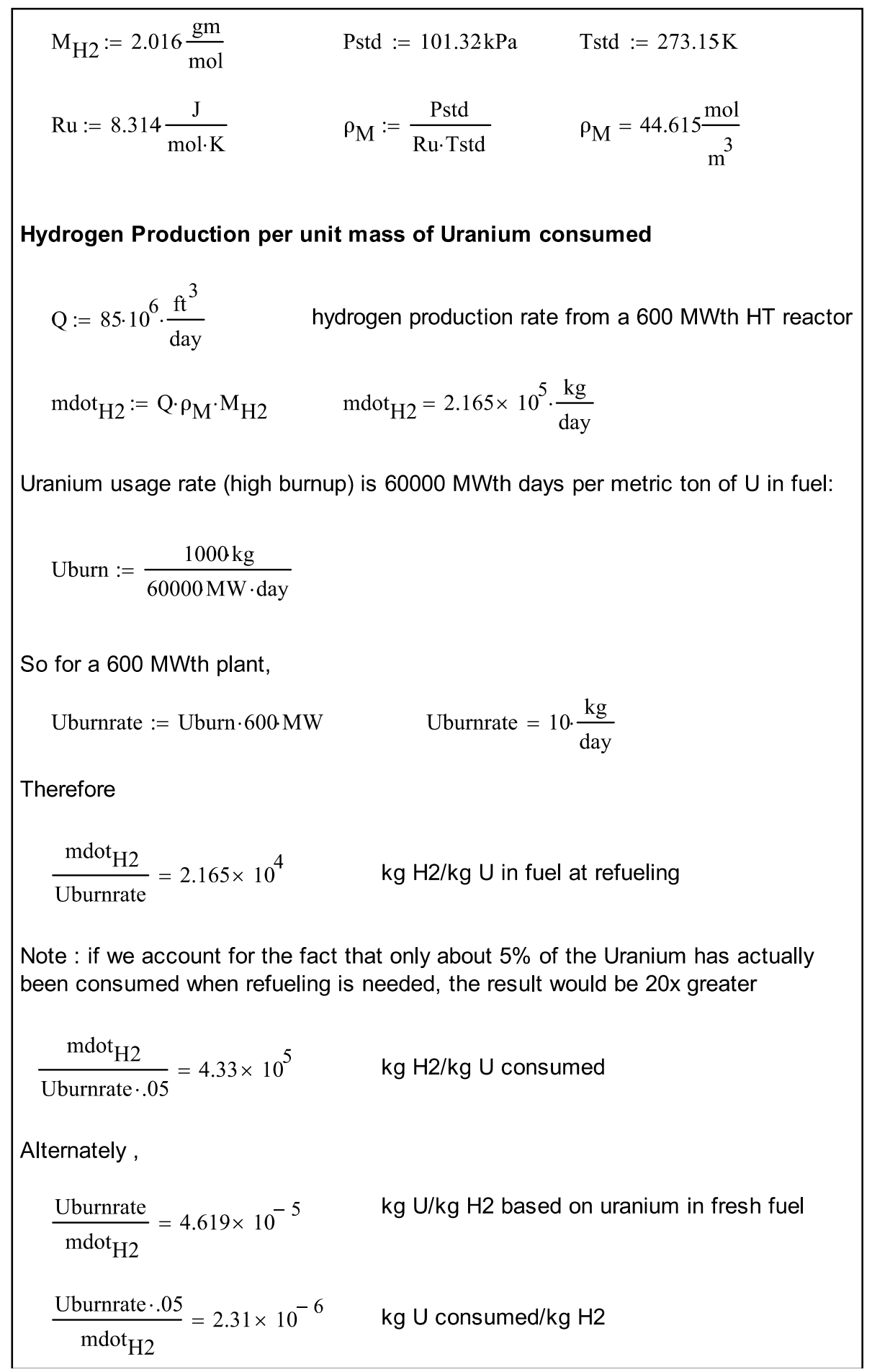

Figure A-1. Assumptions and calculations performed by Jim O'Brien for the uranium-to-hydrogen ratio of an HTE reactor 
The resource potential of uranium in quads (as in Table 9) is calculated from the reserves in million $\mathrm{lb}$ of $\mathrm{U}_{3} \mathrm{O}_{8}$, the heat rate of 10,459 $\mathrm{Btu} / \mathrm{kWh}$ (EIA 2019, average from Table 8.1), and the $398,498 \mathrm{kWh}$ of electricity generated per $\mathrm{kg} \mathrm{U}_{3} \mathrm{O}_{8}$. First the electricity generation from $\mathrm{U}_{3} \mathrm{O}_{8}$ is calculated, based on the plant parameters, as:

$$
\begin{gathered}
\frac{60 \frac{G W d t}{\text { tonne } U} \times \frac{\text { tonne }}{1000 \mathrm{~kg}} \times 1000 \frac{\mathrm{MW}}{\mathrm{GW}} \times 24 \frac{\mathrm{hr}}{\mathrm{day}} \times 3600 \frac{\mathrm{MJ}}{\mathrm{MWh}} \times 947.8 \frac{\mathrm{Btu}}{\mathrm{MJ}} \times 0.848 \frac{\mathrm{kg} \mathrm{U}}{\mathrm{kg} \mathrm{U_{3 } \mathrm { O } _ { 8 }}}}{10,459 \frac{\mathrm{Btu}}{\mathrm{kWh}}} \\
=398,385 \frac{\mathrm{kWh}}{\mathrm{kgU_{3 } O _ { 8 }}}
\end{gathered}
$$

Converting the technical reserves of 353 million $\mathrm{lb}$ of $\mathrm{U}_{3} \mathrm{O}_{8}$ to quads proceeds thusly:

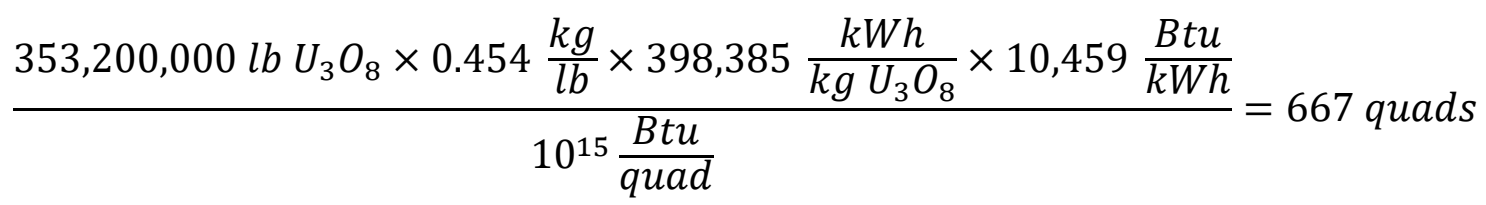

The technical potential of nuclear to produce hydrogen is based on uranium ( $\mathrm{or}_{3} \mathrm{U}_{8}$ ) reserves and the uranium-to-hydrogen ratio of the nuclear plant. For example, the technical potential of HTE plants to produce hydrogen based on 353 million lb of $\mathrm{U}_{3} \mathrm{O}_{8}$ (as shown in Table 9) is calculated as follows:

$$
\begin{gathered}
353,200,000 \mathrm{lb}_{3} \mathrm{O}_{8} \times 0.454 \frac{\mathrm{kg}}{\mathrm{lb}} \times 0.848 \frac{\mathrm{kg} \mathrm{U}}{\mathrm{kgU_{3 } O _ { 8 }}} \times \frac{\mathrm{kg} \mathrm{H}}{4.62 \times 10^{-5} \mathrm{kgU}} \times \frac{M M T}{10^{9} \mathrm{~kg}} \\
=2,942 \mathrm{MMT} \mathrm{H}_{2}
\end{gathered}
$$

To calculate the nuclear energy, in quads (HHV) (see Figure 19), required to produce some set amount of hydrogen, we use the following formulation (assuming $10 \mathrm{MMT}$ ):

$$
\frac{\frac{10 M M T H_{2} \times 10^{9} \frac{\mathrm{kg}}{M M T} \times 120.21 \frac{\mathrm{MJ}}{\mathrm{kg}} \mathrm{LHV} \mathrm{H}_{2} \times 947.8 \frac{\mathrm{Btu}}{\mathrm{MJ}}}{50.2 \%(\mathrm{LHV})} \times \frac{141.9 \frac{\mathrm{MJ}}{\mathrm{kg}} \mathrm{HHV} \mathrm{H}_{2}}{120.21 \frac{\mathrm{MJ}}{\mathrm{kg}} \mathrm{LHV} \mathrm{H} \mathrm{H}_{2}}}{10^{15} \frac{\mathrm{Btu}}{\text { quad }}}
$$

$$
=2.68 \text { quads }
$$

To calculate the nuclear energy requirements in $\mathrm{TWh}$, as in Table 7, the requirement in quads is calculated as above and converted to TWh based on the heat rate of 10,459 Btu/kWh (EIA 2019e, average from Table 8.1). Continuing the example above, the nuclear electricity generation required for $10 \mathrm{MMT}_{2}$ is calculated as:

$$
\frac{2.68 \text { quads } \times 10^{15} \frac{\mathrm{Btu}}{\text { quad }}}{10,459 \frac{\mathrm{Btu}}{\mathrm{kWh}}} \times \frac{\mathrm{TWh}}{10^{9} \mathrm{kWh}}=256 \mathrm{TWh}
$$




\section{Appendix B. Water Consumption Estimates}

The water impacts are based on GREET modeling and related publications. In some instances, parameters were adjusted to reflect assumptions in this report (such as conversion efficiency). The direct water consumption impacts, and associated variability, are from a 2017 EERE Program Record (Han and Elgowainy 2017) and the GREET 2019 model as described in Table B-1. Values from the Program Record were converted from gal $/ 100 \mathrm{mi}$ to gal $/ \mathrm{kg}$ using the assumed fuel economy of $54.1 \mathrm{~kg} / \mathrm{mi}$.

Table B-1. Direct Hydrogen Consumption of Hydrogen Production Technologies

\begin{tabular}{|c|c|c|c|c|}
\hline \multirow[b]{2}{*}{ Technology } & \multicolumn{3}{|c|}{$\begin{array}{l}\text { Direct Water Consumption } \\
\text { (gal/kg) }\end{array}$} & \multirow[b]{2}{*}{ Reference } \\
\hline & Baseline & High & Low & \\
\hline $\begin{array}{l}\text { Centralized Natural Gas } \\
\text { SMR }\end{array}$ & 2.76 & 3.19 & 2.38 & Han and Elgowainy 2017 \\
\hline $\begin{array}{l}\text { Centralized Coal } \\
\text { Gasification }\end{array}$ & 8.22 & 8.44 & 7.57 & Han and Elgowainy 2017 \\
\hline $\begin{array}{l}\text { High-Temperature } \\
\text { Electrolysis }\end{array}$ & 2.11 & 2.24 & 2.11 & $\begin{array}{l}\text { GREET Model including } \\
\text { variablity across versions 2016, } \\
2016 \text { rev1, 2018, } 2019\end{array}$ \\
\hline $\begin{array}{l}\text { Centralized Biomass } \\
\text { Gasification }\end{array}$ & 4.06 & 4.71 & 3.46 & Han and Elgowainy 2017 \\
\hline Distributed Electrolysis & 2.87 & 2.98 & 2.76 & Han and Elgowainy 2017 \\
\hline
\end{tabular}

The upstream water consumption for nuclear HTE consists of the water consumption for running a nuclear power plant. The GREET model lists $0.4 \mathrm{gal} / \mathrm{kWh}$ of electricity produced from nuclear plants (as the direct consumption for producing electricity). Using the HTE electrical efficiency of $23.4 \mathrm{kWh} / \mathrm{kg}$ decribed in Appendix A, this translates to $9.36 \mathrm{gal} / \mathrm{kg}$ hydrogen.

In addition, the water consumption related to uranium mining, transportation, and enrichment must also be taken into account. The GREET model estimates water consumption related to uranium at $432.7 \mathrm{gal} / \mathrm{g}$ uranium. Using the uranium requirement described in Appendix A $\left(4.62 * 10^{-5} \mathrm{~kg}\right.$ uranium $/ \mathrm{kg}$ hydrogen), the estimated water consumption for uranium inputs is $19.99 \mathrm{gal} / \mathrm{kg}$ hydrogen. Thus, the baseline upstream water consumption for hydrogen from nuclear HTE is estimated at $29.35 \mathrm{gal} / \mathrm{kg}$.

The GREET model includes hydrogen production from the following biomass resources: corn stover, willow, poplar, switchgrass, forest residue, and miscanthus. The upstream water consumption, which includes farming and feedstock transportation, for each of these feedstocks differs. The GREET assumptions on feedstock water consumption and energy content are shown in Table B-2 and used to calculate the range of upstream water impacts for hydrogen production, assuming $48.3 \%$ conversion efficiency (see Table 5). In addition, the GREET model shows natural gas and electricity consumption for biomass gasification, so the upstream impacts for the natural gas are then added to the feedstock upstream water consumption. The natural gas and electricity contribute $36 \mathrm{gal} / \mathrm{million} \mathrm{Btu}_{2}(4.1 \mathrm{gal} / \mathrm{kg})$ to the upstream water consumption. 
Table B-3 summarizes the upstream water consumption factors used in this analysis. Not all pathways include high and low values. This does not reflect a lack of variability, only a lack of data on which to base these values. Additional work is proposed to refine the distribution of upstream water consumption values for hydrogen production.

Table B-2. Biomass Feedstock Water Consumption

Source: GREET 2019

\begin{tabular}{|l|c|c|c|}
\hline $\begin{array}{l}\text { Biomass } \\
\text { Feedstock }\end{array}$ & $\begin{array}{c}\text { Water Consumption } \\
\text { (gal/ton biomass) }\end{array}$ & $\begin{array}{c}\text { Energy Content } \\
\text { (Btu/ton } \\
\text { biomass) }\end{array}$ & $\begin{array}{c}\text { Estimated Upstream Water } \\
\text { Consumption for Biomass } \\
\text { Gasification } \\
\text { (gal/kg H }\end{array}$ \\
\hline Corn Stover & 52.59 & $14,716,000$ & $\mathbf{0 . 8 4}$ \\
\hline Willow & 19.41 & $15,396,000$ & $\mathbf{0 . 3 0}$ \\
\hline Poplar & 23.53 & $15,929,000$ & $\mathbf{0 . 3 5}$ \\
\hline Switchgrass & 45.61 & $14,447,000$ & $\mathbf{0 . 7 4}$ \\
\hline Forest Residue & 8.99 & $17,289,000$ & $\mathbf{0 . 1 2}$ \\
\hline Miscanthus & 33.34 & $15,342,000$ & $\mathbf{0 . 5 1}$ \\
\hline
\end{tabular}


Table B-3. Upstream Water Consumption by Hydrogen Production Pathway

\begin{tabular}{|c|c|c|c|c|}
\hline \multirow[b]{2}{*}{ Pathway } & \multicolumn{3}{|c|}{$\begin{array}{c}\text { Upstream Water Consumption } \\
\text { (gal/kg) }\end{array}$} & \multirow[b]{2}{*}{ Reference } \\
\hline & Baseline & High & Low & \\
\hline $\begin{array}{l}\text { Centralized Natural Gas } \\
\text { SMR }\end{array}$ & 0.65 & 0.87 & 0.43 & Han and Elgowainy 2017 \\
\hline $\begin{array}{l}\text { Centralized Coal } \\
\text { Gasification }\end{array}$ & 0.97 & 3.41 & 0.81 & Han and Elgowainy 2017 \\
\hline Nuclear HTE & 29.35 & & & $\begin{array}{l}\text { GREET water consumption for } \\
\text { nuclear power production and } \\
\text { uranium, O'Brien } 2017 \text { for efficiency } \\
\text { and uranium consumption }\end{array}$ \\
\hline $\begin{array}{l}\text { Centralized Biomass } \\
\text { Gasification }\end{array}$ & 4.45 & 4.95 & 4.23 & $\begin{array}{l}\text { GREET water consumption for } \\
\text { biomass feedstocks and } 48.3 \% \\
\text { gasification efficiency; GREET } \\
\text { upstream water for natural gas and } \\
\text { electricity inputs to biomass } \\
\text { gasification }\end{array}$ \\
\hline Wind LTE & 0.05 & & & $\begin{array}{l}\text { GREET water consumption factor } \\
\text { for wind electricity production and } \\
64.9 \% \text { electrolysis efficiency }\end{array}$ \\
\hline Solar LTE & 5.59 & & & $\begin{array}{l}\text { GREET water consumption factor } \\
\text { for solar electricity production and } \\
64.9 \% \text { electrolysis efficiency }\end{array}$ \\
\hline Hydroelectric LTE & 0 & 0 & 0 & $\begin{array}{l}\text { Removed evaporative losses from } \\
\text { GREET water consumption factor }\end{array}$ \\
\hline Geothermal LTE & 55.94 & 79.25 & 44.29 & $\begin{array}{l}\text { GREET water consumption factor } \\
\text { for geothermal electricity production } \\
\text { (flash, binary, ESG) and } 64.9 \% \\
\text { electrolysis efficiency }\end{array}$ \\
\hline
\end{tabular}

